\title{
UTILIZAÇÃO DE CARRAGENA, PECTINA E DE LEITE EM PÓ DESNATADO DE VACA NA ELABORAÇÃO DE IOGURTE DE LEITE DE CABRA DESNATADO
}

\author{
FABIANA PEREIRA BRUZANTIN \\ Farmacêutica-Bioquímica
}

Orientador: Prof. Dr. LUIZ EDUARDO GUTIERREZ

Dissertação apresentada à Escola Superior de Agricultura "Luiz de Queiroz", Universidade de São Paulo, para obtenção do título de Mestre em Ciências, Área de concentração: Ciência e Tecnologia de Alimentos.

P I R A C I C A B A

Estado de São Paulo - Brasil

Setembro - 2000 


\section{ERRATA}

Fabiana Pereira Bruzantin. Utilização de carragena, pectina e de leite em pó desnatado de vaca na elaboração de iogurte de leite de cabra desnatado.

\begin{tabular}{|c|c|c|c|c|}
\hline p. & ítem & linha & onde se lê & leia-se \\
\hline 3 & 2.1 .1 & vinte e um & .... Saanen, & ....Saanen, \\
\hline 41 & 3.3.3.1.1 & três & $\begin{array}{c}\text { Anglorubiana,.... } \\
\text {...salgado (cloreto de } \\
\text { sódio } 0,5 \% \text { ) e amargo } \\
\text { (cafeína } 0,7 \% \text { ). }\end{array}$ & $\begin{array}{c}\text { Anglonubiana,... } \\
\text {.... salgado (cloreto de } \\
\text { sódio } 0,5 \% \text { ) e } \\
\text { amargo ( cafeína } \\
0,07 \%) .\end{array}$ \\
\hline 49 & 4.2 & vinte e três & $\begin{array}{c}\text {....da interação em } \\
\text { nenhum dos } \\
\text { parâmetros (Tabela 3). }\end{array}$ & $\begin{array}{l}\text {....da interação em } \\
\text { nenhum dos } \\
\text { parâmetros (Tabela } \\
\text { 2). }\end{array}$ \\
\hline 53 & 4.3 (tabela 4) & dezesseis & Consistência 7,33 a & Consistência 7,33 b \\
\hline 57 & 4.3 & dez & $\begin{array}{l}\ldots 3,40 \% \text { para } 5,32 \% \\
\text { (Tabelas } 3,4 \text { e } 5 \text { ) }\end{array}$ & $\begin{array}{l}\ldots 3,40 \% \text { para } 5,32 \% \\
\text { (Tabelas } 1 \text { e } 3 \text { ) }\end{array}$ \\
\hline 63 & 4.3 & $\begin{array}{l}\text { vinte e quatro e } \\
\text { vinte e cinco }\end{array}$ & $\begin{array}{c}\text {...atributo } \\
\text { característico, } 6,68 \mathrm{e} \\
\text { por conseqüência, } \\
\text { também para o atributo } \\
\text { de impressão global, } \\
6,27, \ldots .\end{array}$ & $\begin{array}{l}\text {...atributo } \\
\text { característico, } 6,27 \text { e } \\
\text { por conseqüência, } \\
\text { também para o } \\
\text { atributo de impressão } \\
\text { global, } 6,68, \ldots .\end{array}$ \\
\hline
\end{tabular}


Dados Internacionais de Catalogação na Publicação (CIP)

DIVISÃo DE BIBLIOTECA E DOCUMENTAÇÃO - Campus "Luiz de Oueiroz"/USP

\section{Bruzantin, Fabiana Pereira}

Utilização de carragena, pectina e de leite em pó desnatado de vaca na elaboração de iogurte de leite de cabra desnatado / Fabiana Pereira Bruzantin. - - Piracicaba, 2000. $99 \mathrm{p}$.

Dissertação (mestrado) - - Escola Superior de Agricultura Luiz de Queiroz, 2000. Bibliografia.

1. Carragena 2. logurte de leite de cabra 3. Leite em pó 4. Leite de vaca 5. Pectina l. Título

CDD 6377.146 
Aos meu pais

Celso e Marilene

DEDICO

Ao meu irmão Neto

E ao meu noivo Marcelo

OFEREÇO 
"Que é loucura : ser cavaleiro andante ou segui-lo como escudeiro ?

De nós dois, quem é o louco verdadeiro ?

O que, acordado, sonha doidamente?

O que, mesmo vendado,

Vê o real e segue o sonho

de um doido pelas bruxas embruxado?

Eis-me, talvez, o único maluco,

e me sabendo tal, sem grão de siso,

sou - que doideira - um louco de juízo. "

(Carlos Drummond de Andrade) 


\section{AGRADECIMENTOS}

À Deus, fonte da inteligência superior que criou o Universo.

À Escola Superior de Agricultura "Luiz de Queiroz", em especial ao Departamento de Agroindústria, Alimentos e Nutrição, seus professores e funcionários pelos ensinamentos e pelo auxílio na realização deste trabalho.

Ao Prof. Luiz Eduardo Gutierrez, pelo carinho, apoio e orientação na elaboração deste trabalho.

A Profa. Marta Helena Fillet Spoto, pela paciência, compreensão, amizade, ensinamentos e colaboração durante a execução deste trabalho.

Ao Prof. Joaquim Antonio de Oliveira, pela amizade e colaboração em várias etapas deste trabalho.

À Profa. Marília Oetterer, pela amizade e o auxílio para a execução deste trabalho.

À Profa. Ivanete Susin, pelo apoio e colaboração na cessão da matéria-prima.

À Leila Spadoti, pela amizade, incentivo e ajuda em todos os aspectos para a realização deste trabalho.

À Elizabete Teixeira Mendes pelo incentivo e pelo apoio no transcorrer de todo este trabalho. 
À Cleomar Maria de Carvalho, pela amizade e colaboração nas análises laboratoriais.

Ao Prof. Jorge Horii e a secretária da pós-graduação Regina L. M. Lourenço, pelo carinho e auxílio na resolução de questões burocráticas referente ao mestrado.

Às bibliotecárias Beatriz H. Giongo e Midiam Gustinelli, pela amizade e auxílio na parte de consulta e referências bibliográficas.

À todos os meus amigos da ESALQ, em especial Luciana Saboya, Alessandra Cozzo, Sílvia Biscalquin, Roseneide Cella, Giovana Sacco, Antonio Sampaio, André Belluco, Marilisa Tanno, Solange Blummer.

Aos meus familiares e amigos, pelo carinho e incentivo, em especial Maria das Graças, Vera, Renata, Adriana, Maria Elisa, Walquíria, Lucy, Cláudia, Gil, Valéria, Lucimara, Juliana Castilho.

A Coordenadoria do Conselho Nacional de Desenvolvimento Científico e Tecnológico (CNPQ), pela concessão da bolsa de estudo. 


\section{SUMÁRIO}

Página

LISTA DE FIGURAS . $\mathrm{x}$

LISTA DE TABELAS. ..xi

RESUMO ..xii

SUMMARY xiii

1 INTRODUÇÃO. 1

2 REVISÃO BIBLIOGRÁFICA 3

2.1 Leite de cabra 3

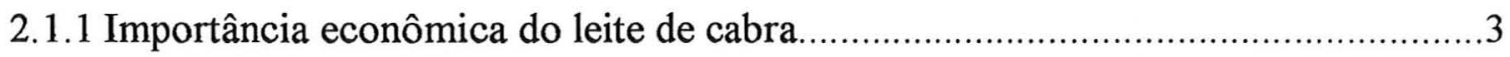

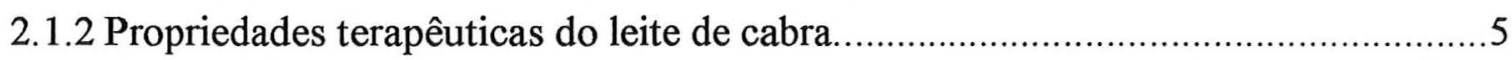

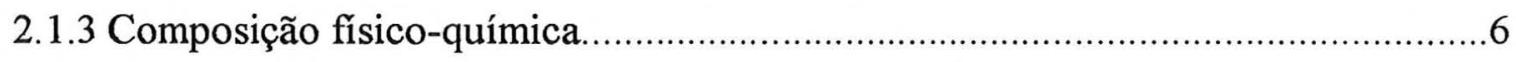

2.1.3.1 Gordura

2.1.3.2 Proteína

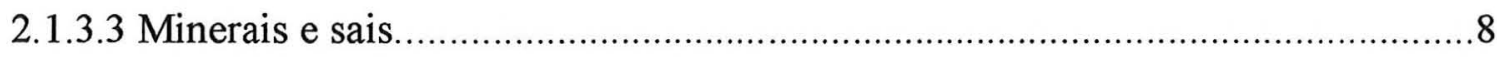

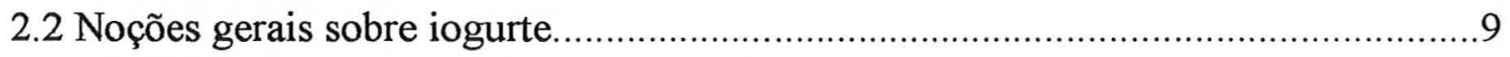

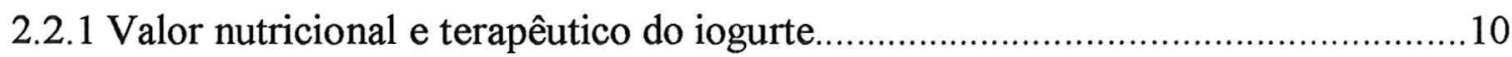

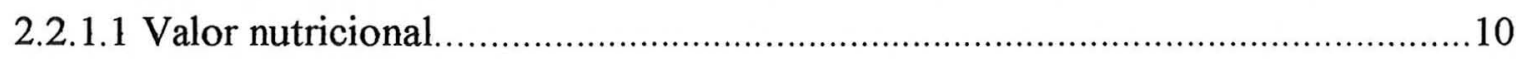

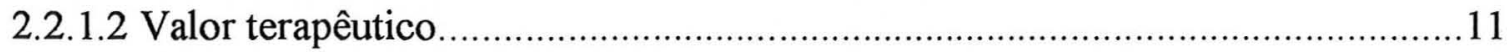




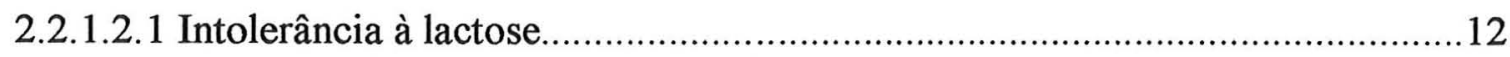

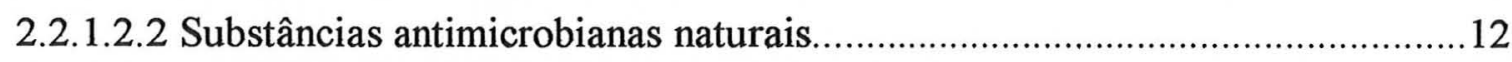

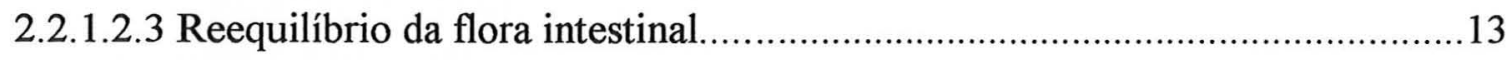

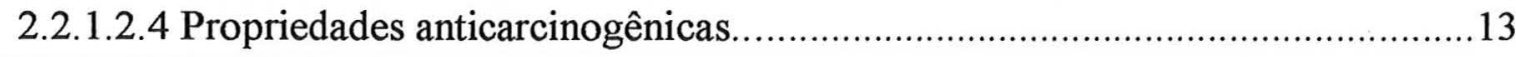

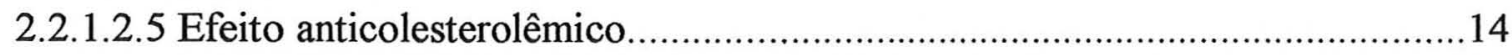

2.2.2 Processamento

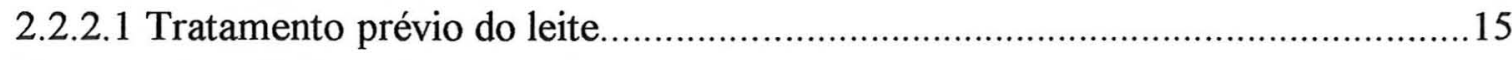

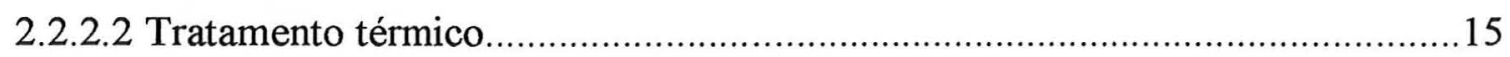

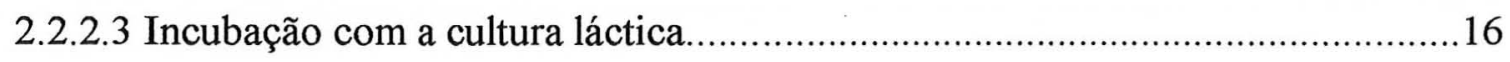

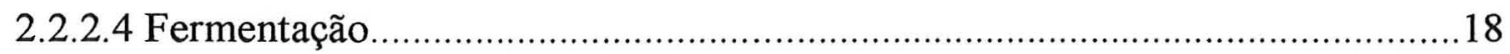

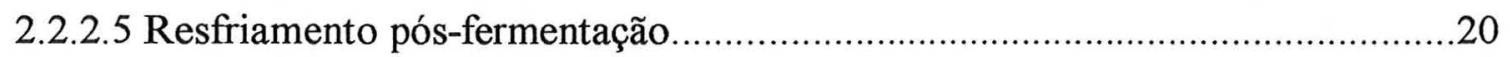

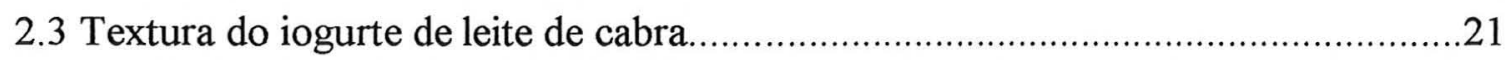

2.4 Uso de espessantes e a correção do teor de sólidos totais no processamento

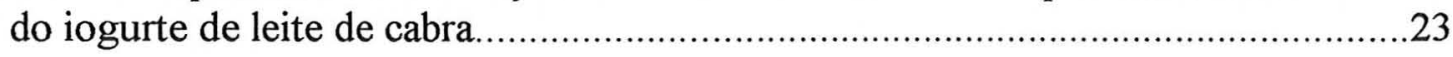

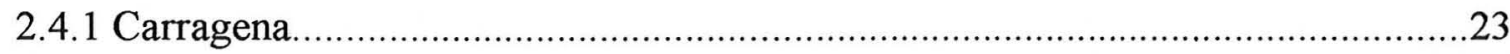

2.4.2 Pectina

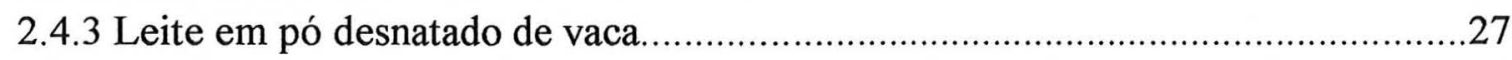

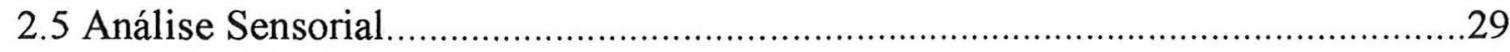

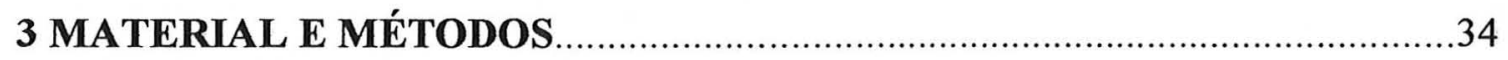

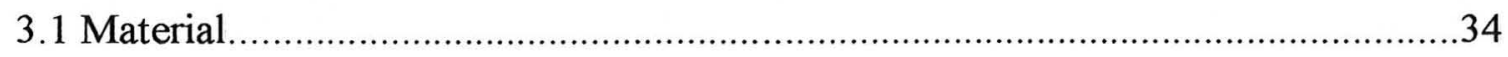




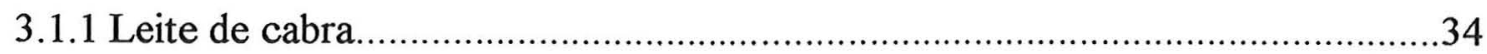

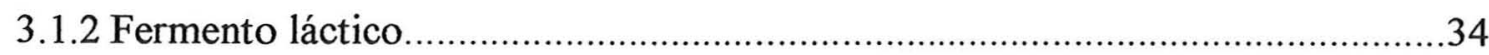

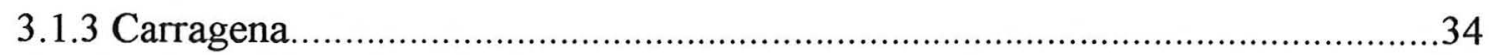

3.1.4 Pectina

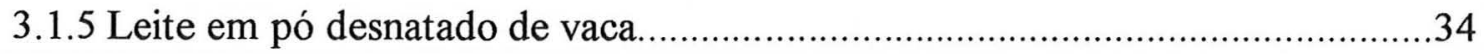

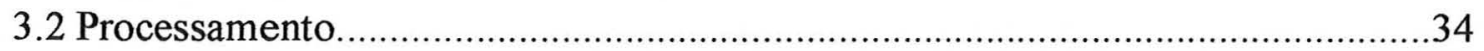

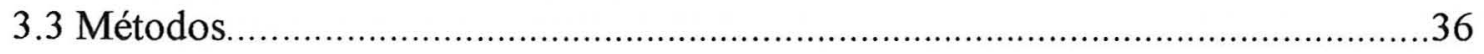

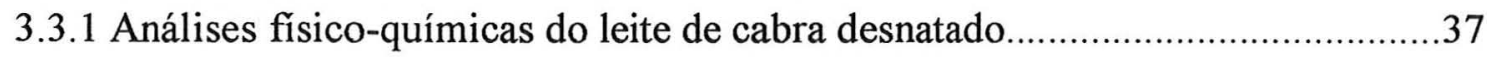

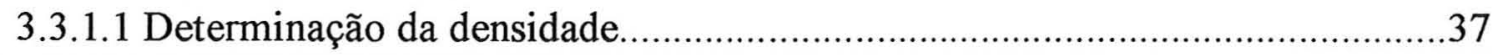

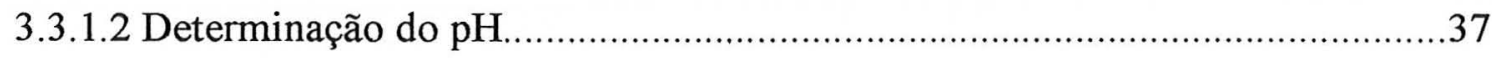

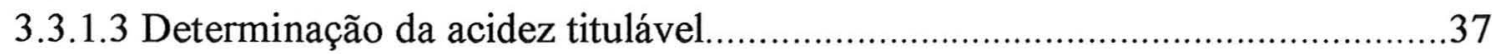

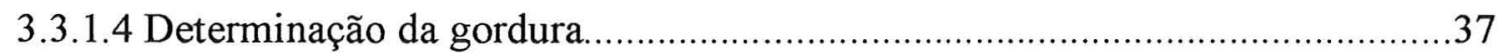

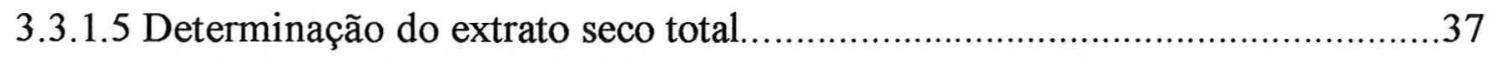

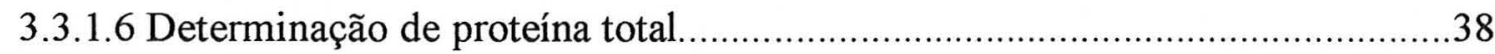

3.3.1.7 Determinação do teor de resíduo mineral fixo (cinzas)....................................38

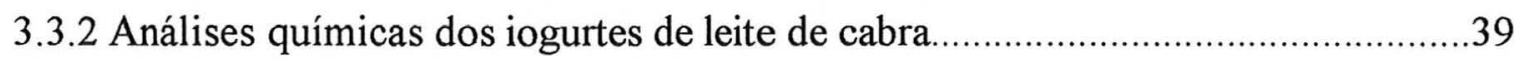

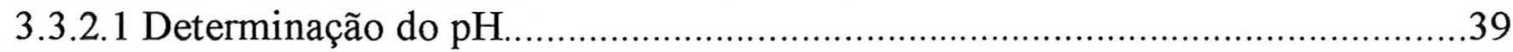

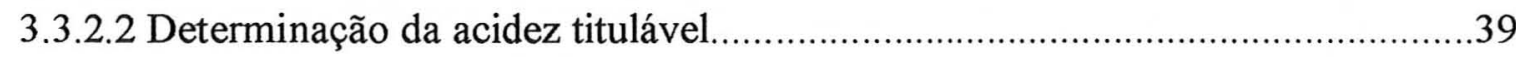

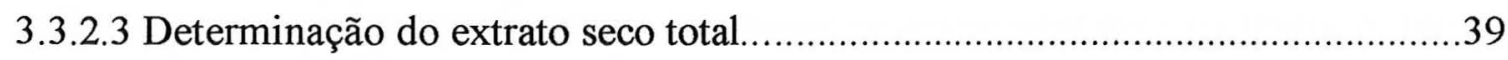

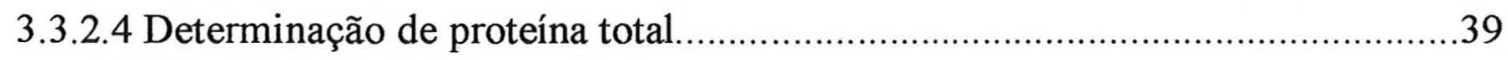

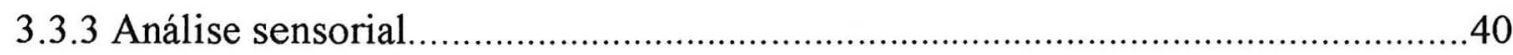

3.3.3.1 Recrutamento e seleção da equipe de provadores..............................................40 
3.3.3.2.1Teste de reconhecimento de sabores.......................................................... 41

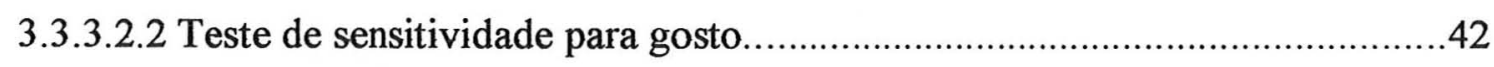

3.3.3.2.3 Treinamento

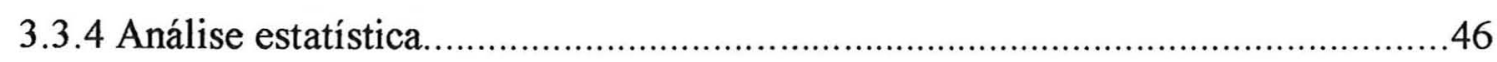

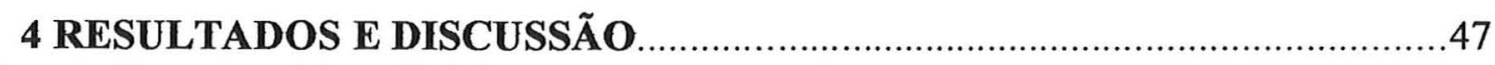

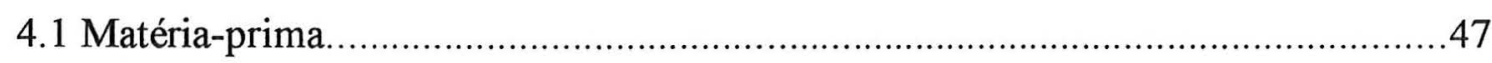

4.2 Análises químicas dos iogurtes de leite de cabra................................................ 49

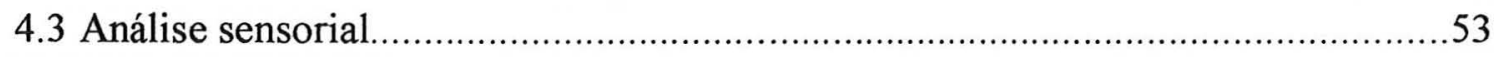

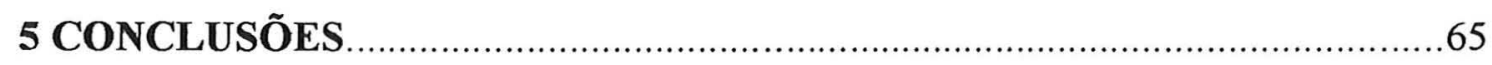

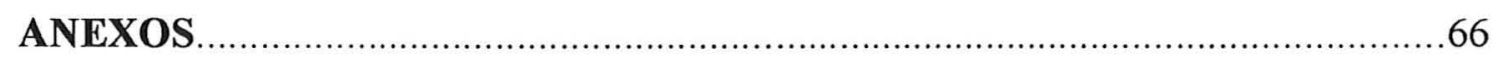

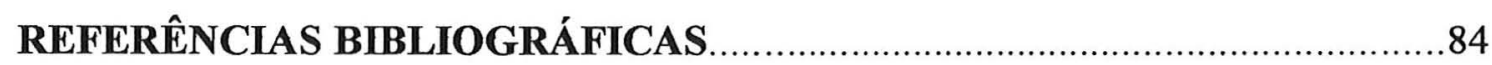




\section{LISTA DE FIGURAS}

Página

1 Produção mundial média, em toneladas/ano de leite de cabra. .4

2 Modelo da ficha de avaliação usada na Fase I da seleção de provadores. 41

3 Modelo da ficha de avaliação usada na Fase II da seleção de provadores.

4 Lista de definições dos termos descritivos para os atributos de aparência, textura e sabor e as respectivas referências utilizadas durante o treinamento e avaliação dos iogurtes de leite de cabra desnatados submetidos a diferentes processamentos...43

5 Modelo da fícha de avaliação da Análise Sensorial dos tratamentos. .45 


\section{LISTA DE TABELAS}

Página

1 Valores médios da composição físico-química do leite de cabra desnatado

2 Valor de F, obtido da análise de variância, para algumas características químicas dos iogurtes de leite de cabra desnatados submetidos a diferentes processamentos. .50

3 Médias e desvio padrão dos valores de $\mathrm{pH}$, acidez titulável, proteína total e extrato seco total dos iogurtes de leite de cabra desnatados submetidos a diferentes processamentos.

4 Nota média dos atributos de aparência cor, consistência e presença de grânulos e Teste de Tukey dos iogurtes de leite de cabra desnatados submetidos a diferentes processamentos.

5 Notas médias dos atributos de textura consistência, viscosidade e presença de grânulos, e Teste de Tukey dos iogurtes de leite de cabra desnatados submetidos a diferentes processamentos. 56

6 Notas médias dos atributos de sabor amargo, doce, característico e impressão global e Teste de Tukey dos iogurtes de leite de cabra desnatados submetidos a diferentes processamentos 


\title{
UTILIZAÇÃO DE CARRAGENA, PECTINA E DE LEITE EM PÓ DESNATADO DE VACA NA ELABORAÇÃO DE IOGURTE DE LEITE DE CABRA DESNATADO
}

\author{
Autora: FABIANA PEREIRA BRUZANTIN \\ Orientador: PROF. DR. LUIZ EDUARDO GUTIERREZ
}

\section{RESUMO}

O leite de cabra é uma opção interessante para a produção de derivados lácteos, principalmente, o iogurte, porque este apresenta elevado valor nutricional e exige baixo investimento para o pequeno produtor de caprinos. Também, torna-se viável para prolongar o período de vida útil do leite e nos períodos de entressafra. Entretanto, o iogurte de leite de cabra natural forma um coágulo menos consistente quando comparado, por exemplo, ao iogurte elaborado com leite de vaca.

Com o objetivo de corrigir esse problema, testou-se o efeito do uso de agentes espessantes como a mistura carragena $0,1 \%$ e pectina $0,1 \%$; pectina $0,5 \%$ e foi feita a correção do teor de sólidos totais para $14 \%$, adicionando-se leite em pó desnatado de vaca (aproximadamente $5 \%$ ). Foram realizadas análises químicas de $\mathrm{pH}$, acidez titulável, proteína total e extrato seco total, nos iogurtes de leite de cabra desnatados no primeiro e no quinto dia após a fabricação. Também no quinto dia foi realizada a análise sensorial dos iogurtes de leite de cabra desnatados, observando os atributos de aparência, textura, sabor e impressão global.

$\mathrm{O}$ iogurte de leite de cabra desnatado adicionado de leite em pó desnatado de vaca foi o preferido pelos provadores, na maioria dos atributos avaliados. 


\title{
USAGE OF CARRAGEENAN, PECTIN AND THE SKIM COW MLK POWDER IN THE PREPARATION OF SKIM GOAT MILK YOGURT
}

\author{
Author: FABIANA PEREIRA BRUZANTIN \\ Adviser: PROF. DR. LUIZ EDUARDO GUTIERREZ
}

\section{SUMMARY}

Goat milk is an interesting option to produce dairy products, mainly, the yogurt because it shows high nutricional value and it is less expensive to the small goat breeders. Also, it is a simple way to increase the shelf life of goat milk while the goat milk production is lower. However, the set skim goat milk has less consistent curd and when compared, for example, with yogurts prepared with goat cow milk.

To solve this problem the effect of the usage of thickeners agents such as the mixture carrageenan $0,1 \%$ and pectin $0,1 \%$; pectin $0,5 \%$ have been studied and the adjustment of total solids to $14 \%$ was made by adding skim cow milk powder (approximately 5\%). Chemical skim goat milk yogurts analyses such as $\mathrm{pH}$, titratable acidity, total protein and total solids in all treatments were realized in the first and the fifth day after the manufacturation. Also, in the fifth day a sensory evaluation was performed and attributes such as appearance, texture, taste and preference were noticed.

Skim goat milk yogurt added with skim cow milk powder was the best treatment for this reason preferred by the painel in most of the analysed attributes. 


\section{INTRODUÇÃO}

O leite de cabra é uma opção interessante para se produzir laticínios, pois quando comparado ao leite de vaca possui melhor digestibilidade, além de muitas vantagens nutricionais.

O iogurte, um produto lácteo fermentado, sempre esteve presente nas civilizações, a princípio fabricado de forma empírica e posteriormente utilizando-se recursos tecnológicos avançados. No mercado atual, o consumo de iogurte tem aumentado gradualmente de acordo com alguns aspectos como estabilidade econômica e, investimentos em propaganda. Várias pesquisas científicas apontam o iogurte como um alimento que possui inúmeras propriedades profiláticas e terapêuticas tais como produção de substâncias antimicrobianas naturais pelas bactérias lácticas, reequilíbrio da flora intestinal, ação anticarcinogênica e anticolesterolêmica entre outras.

A fabricação de iogurte de leite de cabra é economicamente viável pois não necessita de grande investimento de capital por parte do pequeno produtor, além de apresentar grandes vantagens, como o fato de agregar valor nutritivo e representar uma forma de melhor conservação para o leite de cabra por períodos mais longos, pois este apresenta problemas de sazonalidade na produção. Entretanto, o iogurte de leite de cabra apresenta baixa viscosidade. Assim, a adição de espessantes surge então, como uma 
forma alternativa de corrigir os defeitos de viscosidade e consistência deste produto. Outra possibilidade é a utilização de leite em pó desnatado de vaca para a correção do teor de sólidos totais do leite de cabra desnatado, visando corrigir a menor viscosidade e consistência do produto final.

Neste trabalho, procurou-se avaliar a influência da adição dos espessantes carragena e pectina e da adição de leite em pó desnatado de vaca sobre as propriedades químicas e sensoriais do iogurte de leite de cabra desnatado. 


\section{REVISÃO BIBLIOGRÁFICA}

\subsection{LEITE DE CABRA}

\subsubsection{Importância econômica do leite de cabra}

A cabra foi o primeiro animal a ser domesticado, sendo que as primeiras citações datam de 500 anos a.C., na Mesopotâmia (Benedet et al., 1996). As diversas raças se localizam em inúmeros países do mundo e possuem a capacidade de adaptação às mais variadas condições climáticas e topográficas, bem como a fertilidade do solo ou mesmo a alimentação. São capazes de apresentar boa produtividade onde outras espécies animais não sobreviveriam (Lemos-Neto et al., 1993). Segundo Shkolnik et al. (1980), as cabras da raça "Black Bedouin" foram capazes de produzir leite de igual composição, permanecendo de 2 a 4 dias bebendo água apenas uma vez nesse período. Observou-se que as cabras privadas de água perderam 25 a $30 \%$ de peso corpóreo devido à redução da água corporal e do volume de plasma sanguíneo, embora a privação de água não tenha afetado sua alimentação.

Outra vantagem em se criar caprinos é que sua aquisição e manutenção são menos onerosas, sendo uma atividade extremamente atrativa para as menores propriedades rurais. Além disso, as fontes de alimentos utilizadas pelas cabras são escassamente utilizadas pelo gado bovino e menos ainda pelas ovelhas. Por esta razão, o lucro de um criador pode ser maior na criação de cabras, com menor investimento (Baker et al., 1989).

O Brasil possui cerca de 12,6 milhões de cabeças de caprinos. Entre os países com maior rebanho estão a China, com 137.723 .000 e a Índia, com 122.530 .000 cabeças (FAOb, 1999). No Estado de São Paulo, as raças mais comumente encontradas são a Saanen, Anglorubiana, Toggenburg, Parda Alpina e as obtidas por cruzamentos entre 
animais sem raça definida (SRD). Os sistemas de criação mais utilizados são : semiconfinamento, confinamento e extensivo (Lemos-Neto et al., 1993). Segundo Baker et al. (1989), a produção de leite de cabra no Nordeste brasileiro é baixa, aproximadamente $0,8 \mathrm{~L} /$ dia, durante 134 dias; $92 \%$ do rebanho caprino é encontrado nessa região. A raça mais abundante é a Anglorubiana (pura ou cruzada) reconhecida por fornecer carne e leite. A maior produção de leite de cabra ocorre em Pernambuco, tendo como média, $112 \mathrm{~L} / \mathrm{dia}$.

Quadro 1. Produção mundial média, em toneladas/ano de leite de cabra

PAÍS

Índia

Bangladesh

Sudão

Paquistão

França

Grécia

Irã

Somália

Espanha

Rússia

Turquia

China

Indonésia

Ucrânia

Mali

Brasil
TONELADAS/ANO

2.160 .000

1.328 .000

1.062 .000

818.000

480.000

460.000

398.000

390.000

350.000

268.000

249.000

195.304

192.000

189.000

160.800

147.000

Fonte : FAOa, 1999

Embora seja possível observar a expansão da caprinocultura no país, há problemas de sazonalidade na produção do leite de cabra, pois a cabra possui estro sazonal decorrendo apenas uma parição anual, e portanto, um período de lactação variando de seis a oito meses. Dessa forma, há períodos de entressafra, e os produtores são obrigados a armazenar o leite de cabra por congelamento (Benedet et al., 1996; Gomes et al., 1997). 
No Brasil, o leite de cabra e os derivados vêm ganhando crescente mercado através da comercialização de leite integral pasteurizado e congelado, iogurte, principalmente queijos (boursin e moleson), sorvetes, cosméticos, leite de cabra em pó e recentemente leite de cabra esterilizado tipo UHT ("Ultra High Temperature") (Cordeiro, 1998).

\subsubsection{Propriedades terapêuticas do leite de cabra}

O leite de cabra é branco, quando comparado ao leite de vaca, que apresenta coloração amarelada, pela presença de caroteno. O leite de cabra "in natura" é alcalino, sendo extremamente benéfico para pessoas com problemas gástricos. Isso se deve ao fato, do teor de proteína ser maior e haver grupos fosfatos distintos. Desta forma, o leite de cabra pode ser indicado para pessoas com problemas de acidez, eczema, asma, enxaqueca, colite, úlcera estomacal, desordens digestivas, fígado e doenças da vesícula biliar e sintomas de estresse tais como insônia, constipação e indigestão neurótica (Jandal, 1996). Outra propriedade do leite de cabra é o menor teor de lactose deste, sendo portanto, recomendável para indivíduos intolerantes à lactose (Egwu et al. 1995). Furtado et al. (1978), encontraram os seguintes valores para o teor de lactose do leite de cabra e leite de vaca, respectivamente, 4,72 e 4,76.

A alergia ao leite de vaca, resulta de uma reação imunológica anormal às proteínas deste leite, tendo inclusive a presença de imunoglobulina IgE. Esse tipo de reação alérgica é conhecida como reação do tipo I ou de Hipersensibilidade Imediata. O leite de vaca possui 18 a 25 proteínas que podem ter ação alergênica, sendo as mais comuns, a $\beta$-lactoglobulina (fração do soro) e a fração caseína. Os principais sintomas da alergia ao leite de vaca são: diarréia, $88 \%$; vômito, $44 \%$; cólica ou dor abdominal, $39 \%$; dermatite atópica, $33 \%$; rinite, $31 \%$; asma, $31 \%$; urticária, $13 \%$ e anafilaxia, $12 \%$ (Taylor, 1996). Furtado (1981), cita que as principais proteínas alergênicas seriam a $\beta$ lactoglobulina e a $\alpha$-lactoalbumina. As razões para o uso do leite de cabra em substituição ao leite de vaca, estão relacionadas às diferenças na composição protéica. $\mathrm{O}$ 
leite de cabra, por exemplo, não apresenta homólogo à fração caseína- $\alpha_{\mathrm{s} 1}$ e a caseína possui mais glicina, menos arginina e aminoácidos sulfurados.

\subsubsection{Composição físico-química}

\subsubsection{Gordura}

A gordura é um elemento essencial na composição do leite. Sabe-se que, se a ingestão de gordura pelas cabras, for menor que $0,4 \mathrm{~g} / \mathrm{kg}$ por dia, haverá queda na produção de leite e na porcentagem de gordura do mesmo (Jenness, 1980).

No leite de cabra, a composição de ácidos graxos da gordura é de $20 \%$ de ácidos graxos de cadeia curta e média, com 4 a 12 carbonos, incluindo o ácido butírico, capróico, caprílico, cáprico e láurico, todos saturados. Devido a sua composição, a gordura do leite de cabra, sofre digestão mais rápida, por ação das lipases que atacam primeiramente as ligações éster dos ácidos graxos de cadeia curta que os de cadeia longa (Jeness, 1980). Os ácidos graxos capróico, cáprico, caprílico e outros de cadeia média têm sido usados no tratamento de síndromes de má absorção, desordens intestinais, doenças coronárias, nutrição de bebês prematuros, fibrose cística e problemas de cálculo biliar, além de possuírem habilidades únicas de promover energia enquanto reduzem, inibem e dissolvem os depósitos de colesterol. Os ácidos graxos livres, liberados durante a ordenha, são responsáveis pela intensidade maior ou menor do "flavour" indesejável designado de "cheiro de bode" existente no leite de cabra (Jandal, 1996).

Os ácidos graxos estão dispostos na formação dos triglicerídeos em cadeias curtas $\left(\mathrm{C}_{4}\right.$ a $\left.\mathrm{C}_{8}\right)$ sendo esterificados na posição 3 do glicerol; os de cadeia longa $\left(\mathrm{C}_{10}\right.$ ou maiores) na posição 1 ou 2 . O tratamento térmico influencia diretamente no tamanho dos glóbulos de gordura do leite de cabra. Por exemplo, a pasteurização a $61^{\circ} \mathrm{C}$ por 30 minutos, aumenta em $12 \%$ o tamanho dos glóbulos de gordura. Outra particularidade dos glóbulos de gordura do leite de cabra, é a ausência de aglutinina, responsável por unir os glóbulos de gordura após o resfriamento, sendo assim, o leite de cabra é caracterizado por não formar creme (Jeness, 1980). 
Segundo Voutsinas et al. (1990), a proporção de gordura do leite de cabra é reduzida no início da lactação e aumenta, continuamente, nos períodos seguintes. A média do teor de gordura é de 3,44\%. Para Urbiné et al. (1997), o teor de gordura deve estar entre 3,1 e $4,0 \%$.

\subsubsection{Proteína}

As cinco principais proteínas do leite de cabra são a $\beta$-lactoglobulina, $\alpha$ lactoalbumina, $\kappa$-caseína, $\beta$-caseína e a caseína designada caseína- $\alpha_{s 2}$. Elas recebem essa denominação de acordo com a composição e as propriedades das proteínas homólogas ao leite de vaca. Assim como a $\beta$-lactoglobulina bovina, a caprina é uma cadeia polipeptídica de 162 resíduos de aminoácidos. A $\beta$-lactoglobulina caprina possui na posição de $\mathrm{N}$-terminal, isoleucina ao invés de leucina; ácido aspártico na posição 130 ao invés de lisina; serina na posição 150 no lugar da alanina entre outras diferenças. Isso significa que a $\beta$-lactoglobulina caprina possui três cargas negativas a menos e uma positiva a mais que a bovina, implicando em uma mobilidade eletroforética menor da $\beta$ lactoglobulina caprina, em géis alcalinos. A $\alpha$-lactoalbumina caprina não apresenta o aminoácido metionina. Na sequência da cadeia de aminoácidos, há 12 diferenças entre a $\alpha$-lactoalbumina caprina e a $\alpha$-lactoalbumina bovina. A $\kappa$-caseína foi a única fração que teve toda sua sequência de aminoácidos determinada. As diferenças existentes entre as K-caseína bovina e caprina são as seguintes: a א-caseína caprina possui 171 resíduos de aminoácidos na cadeia enquanto a bovina, 169; a valina e a histidina estão inseridas nas posições 132 e 133, e a א-caseína caprina, assim como a bovina, possuem fenilalanina na posição 105 e metionina na posição 106. No total há 19 diferenças na sequência entre os caseínomacropeptídeos de cabra e vaca e 8 entre as para-kappa-caseínas. As $\beta$-caseínas são, em termos quantitativos, os principais componentes protéicos do leite de cabra, faltando pesquisas elucidativas de suas propriedades. No leite de vaca, a presença de caseína- $\alpha_{\mathrm{s} 1}$ em alta concentração torna o sabor do queijo muito mais amargo quando comparado aos queijos fabricados a partir de leite de ovelha e de cabra que apresentam baixas concentrações ou mesmo ausência de caseína- $\alpha_{s 1}$, respectivamente (Jeness, 1980). 
A fração proteose-peptona do leite de cabra e de vaca contém, igualmente, os 18 aminoácidos, porém não nas mesmas concentrações. O leite de cabra apresenta teores elevados de prolina, metionina, tirosina, triptofano, e redução na concentração de ácido siálico, hexose, hexosaminas na fração proteose-peptona, quando comparado ao leite de vaca (Khartoon et al., 1987).

De acordo com Voutsinas et al. (1990), o teor de proteína do leite de cabra aumenta progressivamente com o avanço da lactação. $\mathrm{O}$ valor médio encontrado para a proteína total foi de 3,35\%. Para Benedet et al. (1996) o teor de proteína foi de 3,28\% e Araújo et al. (1986) encontraram o valor, para proteína total, de 4,16\%.

\subsubsection{Minerais e sais}

A presença dos minerais e sais na composição do leite e derivados é extremamente importante pois estes conferem a pressão osmótica fisiologicamente necessária e a estabilização da caseína em suspensão coloidal (Dias et al., 1995).

De acordo com Fuente et al. (1997), o equilíbrio salino no leite pode ser influenciado pelo tempo de armazenamento e pela temperatura. Verificou-se que, em um período de 1 a 7 dias a 3 e $7^{\circ} \mathrm{C}$, os teores de cálcio divalente e fósforo aumentaram na fase solúvel, sendo este fato particularmente notado para o leite de cabra. Após 2 dias a $3^{0} \mathrm{C}$, houve um aumento de cálcio, magnésio e fósforo no soro do leite de cabra. Conforme o $\mathrm{pH}$ diminuía, notou-se o aumento de elementos traços na fase solúvel. Para as amostras de leite congeladas, as concentrações de fósforo, cálcio e magnésio coloidais aumentaram.

O teor de cinzas aumenta progressivamente com o período de lactação, principalmente, para as concentrações de cálcio, fósforo e magnésio. A concentração de citrato apresentou a maior variação, decrescendo durante a lactação, o mesmo acontecendo com o teor de potássio (Voutsinas et al., 1990). O teor de cinzas no leite de cabra, segundo Urbiéne et al. (1997) foi de 0,74\% a 0,77\%. Entretanto para Bonassi et al., (1997), estes valores estiveram entre 0,63 a $0,90 \%$.

Um problema apontado para a ingestão de leite, de um modo geral, é a deficiência no elemento ferro, que seria mal absorvido pelo organismo humano (Furtado, 
1981; Jeness, 1980). Park et al. (1986), avaliaram a biodisponibilidade do ferro nos leites de cabra e de vaca integrais e desnatados, utilizando-se de ratos induzidos a apresentar deficiência neste mineral. A eficiência de regeneração da hemoglobina foi determinada como a porcentagem de conversão da dieta adicionada de ferro em hemoglobina. Nos grupos alimentados com leite de cabra e vaca integrais e leite de cabra e vaca desnatados, as eficiências de regeneração da hemoglobina foram, respectivamente, de $50,6 \% ; 13,1 \% ; 26,0 \% ; 13,0 \%$ indicando que a biodisponibilidade do ferro nos dois tipos de leite de cabra foi maior que nos dois leites de vaca.

\subsection{NOÇÕES GERAIS SOBRE IOGURTE}

O iogurte é um produto originário do Oriente Médio, utilizado pelos povos nômades que, devido ao clima da região e a falta de outros tratamentos específicos, provocavam modificações no leite, sendo a coagulação uma etapa inevitável. Posteriormente, estes povos passaram a utilizar a fermentação do leite como uma maneira de preservação da matéria-prima. A palavra iogurte é proveniente da Turquia, uma adaptação ao termo "jugurt". Somente em 1950, o iogurte passou a ser consumido com maior freqüência na Europa Ocidental e América do Norte (Tamime et al., 1985).

Segundo a legislação vigente, o iogurte é o produto adicionado ou não de outras substâncias alimentícias, obtido por coagulação e diminuição do pH do leite, ou leite reconstituído, adicionado ou não de outros produtos lácteos, por fermentação láctica mediante ação de cultivos proto-simbióticos de Streptococcus salivarius subsp. thermophilus e Lactobacillus delbrueckii subsp. bulgaricus aos quais pode se acompanhar, de forma complementar outras bactérias ácido-lácticas que, por sua atividade, contribuem para a determinação das características do produto final (Brasil, 1998).

O consumo de iogurte no Brasil vem aumentando, devido à estabilidade econômica facilitando ao consumidor a aquisição deste produto que, anteriormente não fazia parte de sua mesa. Consome-se no Brasil cerca de $2 \mathrm{~kg}$ de iogurte, por pessoa, ao 
ano, ao passo que na França o consumo é de $25 \mathrm{~kg}$ por pessoa ao ano (Consumo...., 1997).

\subsubsection{Valor nutricional e terapêutico do iogurte}

\subsubsection{Valor nutricional}

O iogurte é um alimento com um elevado valor nutricional e pode ser compreendido avaliando-se seus vários componentes. Os carboidratos disponíveis no iogurte natural estão presentes como mono- e dissacarídeos em quantidades pequenas, apresentando em média 6,4\%; considerando que cada grama de açúcar fornece 4 calorias pode-se então considerar este alimento como importante fonte de energia em dietas que carecem de alimentos energéticos. Já os carboidratos indisponíveis, como por exemplo a carragena, que são longas cadeias de polissacarídeos, apresentam as seguintes propriedades: estimulação do peristaltismo intestinal, absorção de substâncias químicas tóxicas formadas no intestino grosso por ação de bactérias e promoção da retenção dos açúcares na parede intestinal, especialmente no caso de pacientes intolerantes à lactose. As proteínas do leite são excelentes quanto à qualidade biológica e tanto a caseína quanto as proteínas do soro são ricas em aminoácidos essenciais. Dois fatos importantes em relação às proteínas no iogurte: elas se encontram totalmente digeridas; e como já estão previamente coaguladas antes da ingestão, formam um coágulo mais suave que não causa qualquer sensação de desconforto, facilitando a ação de enzimas proteolíticas durante a digestão. Quanto aos lipídeos no iogurte, estes são responsáveis pela consistência, paladar, como fonte de energia, principalmente para crianças que vivem em países em desenvolvimento, e como fonte de ácidos graxos. É difícil avaliar a disponibilidade das vitaminas no iogurte pois elas são afetadas pelas condições de processamento. As principais vitaminas, em unidades $/ 100 \mathrm{~g}$, presentes no iogurte de leite desnatado são: vitamina $A$, 70; vitamina $B_{1}, 42$; vitamina $B_{2}, 200$; vitamina $B_{6}$, 46; vitamina $B_{12}, 0,23$; vitamina $C, 0,7$; ácido fólico, 4,1; ácido nicotínico, 125 ; ácido pantotênico, 381; biotina, 2,6; e colina, 0,6 (Tamime et al., 1985). 
Kneifel et al. (1992) estudaram a capacidade de síntese de vitaminas por parte de culturas mesofilicas em leites de vaca cultivados, e notaram um aumento na concentração de tiamina, piridoxina, ácido fólico e ácido pantotênico. Por outro lado, as concentrações de riboflavina e ácido nicotínico permaneceram constantes enquanto o teor de cianocobalamina e ácido orótico foram reduzidos.

Panfili et al., (1998), observaram que ocorria a isomerização cis-trans da vitamina $\mathrm{A}$, especialmente em leites de vaca que sofreram tratamento térmico, e que direta ou indiretamente passaram pelo processo fermentativo.

Estudos recentes sugerem que há ação protetora do folato na redução de defeitos do tubo neural e possivelmente sobre doenças cardíacas e câncer. Wigertz et al. (1997), avaliaram e quantificaram a presença de folato em treze tipos de produtos lácteos de vaca como leite em pó desnatado, leite pasteurizado, leite UHT ("Ultra High Temperature"), leites fermentados, produtos à base de soro e queijos. Observou-se que os teores de folato encontrados no leite fermentado e leite UHT submetidos à temperaturas maiores que $90^{\circ} \mathrm{C}$ durante o processamento, foram os menores quando comparados aos outros produtos lácteos.

\subsubsection{Valor terapêutico}

A fermentação é um dos mais antigos métodos para a preservação de alimentos, especialmente o leite. Praticamente todas os países apresentam algum tipo de leite fermentado característico, preparados muitas vezes, de forma empírica. Por outro lado, atualmente, os leites fermentados são produzidos a partir de microorganismos cuidadosamente selecionados que não apresentam apenas ações bioquímicas e biológicas sobre os nutrientes mas que possuem efeitos fisiológicos e terapêuticos sobre o consumidor (Alm, 1997). O iogurte, o leite acidófilo e o yakult são exemplos de diferentes tipos de leites fermentados. Esses produtos estão relacionados ao reequilíbrio da flora intestinal, intolerância à lactose, efeitos anticarcinogênicos e anticolesterolêmico, etc. (Saboya et al., 1997). 


\subsection{Intolerância à lactose}

Nos casos de intolerância à lactose, há ausência da enzima responsável pela hidrólise da lactose em glicose e galactose. Essa enzima é conhecida como lactase ou $\beta$ D-galactosidase e a doença provocada por sua ausência é a galactosemia. Então, os indivíduos intolerantes podem utilizar produtos fermentados, cujos microorganismos presentes produzem esta enzima, contribuindo para a degradação da lactose (Furtado, 1981; Kilara et al., 1978).

Goodenough et al. (1976a), utilizaram ratos de laboratórios alimentados com vários tipos de iogurte, como o iogurte natural, pasteurizado, adicionado de açúcar, para avaliar a viabilidade da microflora do iogurte sobre a digestão da lactose. Os ratos foram alimentados por sete dias consecutivos com os iogurtes. Os estudos mostraram que os ratos alimentados com iogurte natural foram os que apresentaram maior capacidade em absorver a galactose e que a sobrevivência gastrointestinal da cultura láctica foi de três horas após a ingestão do iogurte.

\subsection{Substâncias antimicrobianas naturais}

Os microrganismos responsáveis pela produção de iogurte e leite acidófilo são respectivamente Lactobacillus delbrueckii subsp. bulgaricus, Streptococcus salivarius subsp. thermophilus e Lactobacillus acidophilus que produzem metabólitos durante o crescimento e possuem considerável importância na saúde humana (Ferreira, 1979). O Streptococcus salivarius subsp. thermophilus estaria relacionado com a produção de dezessete tipos de bacteriocinas do leite, entre elas, as duas mais conhecidas são a STB40 e STB78. As bacteriocinas, são de um modo geral, proteínas antimicrobianas ou oligopeptídeos, que possuem uma atividade antibacteriana mais acentuada que os antibióticos, sendo mais ativos principalmente contra bactérias taxonomicamente próximas às próprias cepas produtoras, que normalmente são imunes à sua própria bacteriocina (De Vuyst, 1994). Outros autores salientam que o Streptococcus salivarius subsp. thermophilus produz mais de um composto antimicrobiano e que seriam aminas de baixo peso molecular e estáveis ao calor (Pulusani et al. 1979). Abdel-bar et al. 
(1987), realizaram estudos com culturas de Lactobacillus delbrueckii subsp. bulgaricus para verificar a produção de substâncias antibióticas diferentes do ácido láctico. Foi encontrada uma substância antibiótica ativa contra o Pseudomonas fragi e Staphylococcus aureus, que apresentou atividade no $\mathrm{pH}$ ótimo de 4,0. Neste $\mathrm{pH}$, a substância ativa foi isolada e purificada utilizando a metodologia da cromatografia líquida de alta resolução de fase reversa. Posteriormente, foi realizado o teste do Biureto e observou-se através do teste negativo, que a substância purificada não era um polipeptídeo. Utilizando-se técnicas de absorção ultra-violeta e espectro de massa concluiu-se que o composto apresentava estrutura aromática e peso molecular menor ou igual 700 .

Essas culturas produtoras de ácido láctico contribuem para aumentar a vida útil e promover a inibição de patógenos. Os principais microrganismos inibidos pelas substâncias antimicrobianas são: Staphylococcus aureus, Pseudomonas putrifaciens, Escherichia coli, Clostridium perfringens, etc (Saboya et al., 1997).

\subsection{Reequilíbrio da flora intestinal}

Segundo Ferreira (1979), a ingestão de doses elevadas de lactobacilos através dos leites fermentados influencia, positivamente, na composição da flora intestinal desequilibrada, em certos casos, pelo tratamento oral extensivo com antibióticos.

O uso de Lactobacillus acidophilus e/ou bifidobactérias contidos nos leites fermentados são responsáveis por restabelecer o equilíbrio da flora intestinal quando ocorrem problemas como diarréia ou flatulência que têm origem pela ação de microrganismos patogênicos (Saboya et al., 1997).

\subsection{Propriedades anticarcinogênicas}

As propriedades anticarcinogênicas possuem ainda um número relativamente pequeno de estudos quando comparadas ao uso de bactérias lácticas no tratamento de doenças bacterianas e virais. No caso do iogurte, somente sua fração sólida foi associada à capacidade de reduzir o número de células carcinogênicas. E ainda que o Lactobacillus 
delbrueckii subsp. bulgaricus teria atividade inibitória em tumores e não o Streptococcus salivarius subsp. thermophilus através de três mecanismos básicos: eliminação de prócarcinogênicos, modulação de enzimas pró-carcinogênicas e supressão do tumor (Farmer et al., 1975). Estudos recentes indicam que 20 a 60\% da incidência de câncer está relacionada com a alimentação. Algumas evidências sugerem que proteínas, ácido linoléico conjugado, lactose, cálcio e ácido butírico presentes no leite fermentado apresentam propriedades anticarcinogênicas (Fonseca et al., 1999).

Segundo Perdigón et al., (1998), foram realizados estudos com ratos alimentados com iogurte por 2, 5, 7 e 10 dias consecutivos. Verificou-se que o uso de iogurte induziu uma grande redução na reposta inflamatória e inibiu o crescimento do tumor de cólon. Dentre os grupos testados, observou-se que o tumor foi inibido em ratos alimentados com iogurte entre 7 ou 10 dias de tratamento. Com relação ao sistema imunológico dos ratos avaliados houve um aumento nas células de defesa, como por exemplo, a imunoglobulina IgA.

\subsection{Efeito anticolesterolêmico}

As doenças arterioscleróticas associadas a um elevado número de mortes vêm acometendo cada vez mais pessoas todos os anos e a hipercolesterolemia é uma de suas causas. Por este motivo, os consumidores estão mais preocupados com a saúde e adquirindo alimentos que auxiliem na redução do nível de colesterol sangüíneo (Saboya et al., 1997).

Um grupo de vinte e quatro homens jovens divididos em dois grupos de doze foram alimentados com leite fermentado por vinte e um dias. Um dos grupos ingeriu o leite fermentado com $10 \mathrm{mg}$ de Tween 20/g de gordura e o grupo controle foi alimentado com placebo composto de óleo de oliva. Em ambos os grupos, houve rápido aumento de peso. Curiosamente, o ganho de peso ocasionou, ao mesmo tempo, redução na taxa de colesterol devido, possivelmente, a presença de algum fator específico presente no leite fermentado. Esse fator poderia ser responsável pela supressão ou inibição da síntese de 
colesterol endógeno reduzindo conseqüentemente o nível de colesterol sérico (Mann et al., 1974).

Beena et al. (1997), realizaram pesquisas com ratos alimentados com iogurte adicionado de soro condensado de lactose hidrolisada e verificaram que todos os iogurtes contendo cultura composta por bifidobactérias reduziram o colesterol sérico. Houve também uma redução considerável do colesterol LDL ("low density lipoproteins") em ratos alimentados com as proteínas do soro. Este fato sugere que possivelmente os mesmos efeitos possam ocorrer em humanos.

\subsubsection{Processamento}

\subsubsection{Tratamento prévio do leite}

O tratamento prévio do leite é a etapa inicial do processamento do iogurte, pois é feita a padronização da matéria-prima, que resultará no tipo de iogurte desejado. A padronização do leite engloba, principalmente, o ajuste no teor de sólidos totais do leite, através da adição de leite em pó e da concentração de gordura presente. Vários autores concordam que o teor de sólidos do leite para a produção de iogurte deve variar de 12 a $17 \%$. Essa modificação na composição do leite afetará algumas variáveis físico-químicas como o pH, a acidez titulável e a viscosidade do iogurte (Araújo et al., 1993; Neirotti et al., 1988; Wolfschoon-Pombo et al., 1983 ).

Os leites fermentados integrais são os que possuem um conteúdo mínimo de $3,0 \%$ de matéria gorda; os parcialmente desnatados têm valor máximo de até $2,9 \%$ de matéria gorda e os desnatados apresentam um conteúdo máximo de matéria gorda de 0,5\% (Brasil, 1998).

\subsubsection{Tratamento térmico}

O tratamento térmico é empregado no processamento de iogurte com o objetivo de aumentar a concentração de sólidos do leite dentro da mistura básica. Outros efeitos provocados pelo tratamento térmico são a destruição e/ou eliminação de patógenos e 
outros microrganismos indesejáveis; produção de fatores que estimulem ou inibam as culturas lácticas do iogurte e mudanças nas propriedades físico-químicas dos constituintes do leite (Tamime et al., 1985). Os autores concluíram que houve uma relação linear $(\mathrm{P}<0.001)$ entre a drenagem do soro e a proteína do soro desnaturada para os iogurtes preparados com leite em pó desnatado de vaca reconstituído, mostrando a relação direta sobre a resistência dos iogurtes a sofrerem sinérese (Augustin et al., 1999b).

A combinação tempo-temperatura, usada no tratamento térmico da mistura para a fabricação do iogurte, resulta em um tratamento muito superior ao necessário para uma simples pasteurização (Brandão, 1995). Em trabalhos específicos para iogurtes fabricados com leite de cabra, Loewnstein et al. (1980) citaram o uso do tratamento térmico de $80^{\circ} \mathrm{C}$ por $15 \mathrm{~min}$. e Araújo et al. (1986), $85^{\circ} \mathrm{C}$ por $15 \mathrm{~min}$. Hashimoto (1994) afirmou que o melhor tratamento térmico utilizado seria de $90^{\circ} \mathrm{C}$ por 5 min tanto em termos de características físico-químicas como reológicas desejáveis, implicando, portanto, num maior grau de desnaturação da $\beta$-lactoglobulina caprina.

Parnell-Clunies et al. (1987), utilizaram os seguintes tratamentos térmicos ao leite de vaca para posterior produção de iogurte: $85^{\circ} \mathrm{C}$ por $10 \mathrm{~min}$ (VAT), alta temperatura-tempo curto (HTST), $98^{\circ} \mathrm{C}$ por 1,87 min e temperatura ultra elevada (UHT), $140^{\circ} \mathrm{C}$ por $6 \mathrm{seg}$. Os iogurtes fabricados com leites que sofreram tratamento térmico, apresentaram uma rede contínua e mais fina em sua estrutura, composta por partículas de caseína menores e com mais ligações entre elas. Por outro lado, o iogurte que não foi submetido a tratamento térmico, teve menor consistência na coalhada e também menor capacidade de reter água pois apresentou uma rede protéica com partículas de caseína maiores e unidas em ramos.

\subsubsection{Incubação com a cultura láctica}

A etapa de incubação com a cultura láctica, é especialmente importante, pois há a transformação do preparo do iogurte de arte para ciência. A produção de acidez e o "flavour" no iogurte originam-se basicamente da simbiose bacteriana do Streptococcus 
salivarius subsp. thermophilus e o Lactobacillus delbrueckii subsp. bulgaricus. A proporção final de cultura láctica no processamento do iogurte deve ser de 1:1, dependendo de ajustes exclusivamente no tempo e temperatura de incubação (Kroeger, 1976).

A proporção entre cocos e bacilos pode ser influenciada também pela quantidade de inóculo, concentração muito elevada de sólidos solúveis (por exemplo o açúcar), pela proporção inicial de cocos/bacilos no fermento utilizado, pela presença de antibióticos e outros resíduos no leite, entre outros (Brandão, 1995).

A temperatura ideal de incubação da cultura láctica é de $42^{\circ} \mathrm{C}$ para a maioria dos autores consultados (Araújo et al., 1986; Loewenstein et al., 1980; Neirotti et al., 1988).

Radke-Mitchell et al., (1986), verificaram o efeito da temperatura sobre o crescimento associativo do Streptococcus salivarius subsp. thermophilus e do Lactobacillus delbrueckii subsp. bulgaricus. Era esperado que à $45^{\circ} \mathrm{C}$, a cultura dominante fosse composta de Lactobacillus delbrueckii subp. bulgaricus enquanto que a $37^{\circ} \mathrm{C}$, o crescimento do Streptococcus salivarius subsp. thermophilus fosse favorecido. Entretanto, esses modelos de crescimento observados com a temperatura controlada foram muito diferentes do previsto. As cepas de Streptococcus salivarius subsp. thermophilus obtiveram maior número de células que o Lactobacillus delbrueckii subp. bulgaricus às temperaturas de $37^{\circ} \mathrm{C}, 42^{\circ} \mathrm{C} \mathrm{e} 45^{\circ} \mathrm{C}$ em $93,3 \%$ das culturas mistas testadas. A proporção média de bacilos/cocos obtidos a $37^{\circ} \mathrm{C}, 42^{\circ} \mathrm{C}$ e $45^{\circ} \mathrm{C}$ foi de $1: 22$, $1: 8$ e $1: 2,4$, respectivamente. As temperaturas ótimas de crescimento não exerceram influência sobre o crescimento da cultura mista composta de Streptococcus salivarius subsp. thermophilus e de Lactobacillus delbrueckii subp. bulgaricus, porém, a temperatura influenciou a compatibilidade das culturas, porque determinou a concentração ou tipos de fatores estimulatórios produzidos pelo Lactobacillus delbrueckii subp. bulgaricus. 


\subsubsection{Fermentação}

Após o tratamento térmico, o leite é resfriado à temperatura de incubação adequada para a ação da cultura láctica, por volta de 2 horas e meia. Independente do tipo de iogurte a ser produzido, as reações bioquímicas para a formação do gel ou coágulo são exatamente as mesmas. Algumas diferenças podem existir entre os tipos de iogurte com relação, por exemplo, as propriedades reológicas de coágulo. Para que o gel seja formado são necessárias algumas modificações biológicas e físicas no leite como a utilização da lactose pelas culturas lácticas e posteriormente formação de ácido láctico; a ação do ácido láctico sobre a micela de caseína; denaturação das proteínas do soro pela solubilização do fosfato de cálcio e citratos; a agregação das micelas de caseína e/ou outros grupos de micelas e que parcialmente coalescem no $\mathrm{pH}$ correspondente ao ponto isoelétrico $(4,6$ a 4,7); há provável interação da $\alpha$-lactoalbumina com a $\beta$-lactoglobulina que são parcialmente protegidas pelas micelas contra a desestabilização ou quebra. Portanto, forma-se uma rede em forma de gel, com uma estrutura regular, que mantém estáveis os outros constituintes da mistura básica, incluindo a fase aquosa. (Tamime et al., 1985).

Durante o processamento fermentativo do iogurte, ocorrem mudanças qualitativas e quantitativas sobre os carboidratos presentes no leite. De acordo com Goodenough et al. (1976b), o teor médio de lactose da mistura do iogurte inicialmente variou de $8,50 \%$ e decresceu para $5,75 \%$ durante toda a fermentação. O teor inicial de galactose era mínimo entretanto, aumentou para $1,20 \%$ durante a fermentação enquanto o teor de glicose permaneceu muito baixo durante todo o processo fermentativo. Toba et al. (1983), citam que o teor inicial de lactose do iogurte $(6,53 \%)$ decresceu progressivamente para $4,22 \%$ durante a fermentação; o teor de galactose era de $0,04 \%$ mas aumentou progressivamente para $1,46 \%$.

Quando comparado ao leite de vaca, o iogurte de leite de cabra apresentou maior teor de acidez titulável, respectivamente, $0,64 \%$ e $0,76 \%$ de ácido láctico, sendo que ambos iogurtes foram preparados sob as mesmas condições. Possivelmente, isso deva ter 
ocorrido por diferenças na composição e nas características particulares existentes nos dois tipos de leite. Um exemplo, seria a presença de grande quantidade de pequenos peptídeos não-protéicos e maiores concentrações de algumas frações de fosfolipídeos presentes no leite de cabra que poderiam agir como um fator estimulante para o desenvolvimento da cultura láctica neste iogurte (Jenness, 1980; Manjunath et al., 1983).

Hassan et al. (1995), observaram através da microscopia laser de varredura confocal a formação do coágulo resultante da acidificação do leite de vaca. Foi averigüado que a gelatinização ocorreu inicialmente a $\mathrm{pH}$ 5,35 quando houve a agregação das micelas de caseína e interrupção do movimento celular.

O "flavour" para o iogurte como para qualquer outro alimento é essencial para a sua aceitabilidade e comercialização. Um dos mais importantes problemas tecnológicos no iogurte é a ausência de aroma e "flavour" típicos (Rash, 1990). Os compostos responsáveis pelo aroma e "flavour" característicos do iogurte são substâncias voláteis produzidas pelos microrganismos da cultura láctica tradicional e incluem o acetaldeído, diacetil, etanol e ácidos orgânicos voláteis. O acetaldeído é proveniente da descarboxilação do piruvato e pode ser reduzido à etanol. O diacetil é produzido por microrganismos citrato-fermentativos capazes de reduzir esse composto para um produto de aroma característico (Keenan et al., 1968). Hamdam et al. (1971), estudaram a concentração de acetaldeído produzida por três marcas de iogurtes comerciais após sete horas de incubação à $45^{\circ} \mathrm{C}$ e por 4 semanas de armazenamento a $4^{0} \mathrm{C}$. Todas os três tipos de iogurte produziram de 22 a 26 ppm de acetaldeído e após $5 \mathrm{~h}$ de fermentação os teores declinaram, ocorrendo o mesmo fenômeno durante o armazenamento. Bottazzi et al. (1967), avaliaram as concentrações de acetaldeído e diacetil produzidas por cepas de Streptococcus lactis, Streptococcus cremoris, Streptococcus diacetilactis, Streptococcus faecalis e Streptococcus salivarius subsp. thermophilus em leite desnatado e meio MRS. Em ambos os meios testados todas as cepas de Streptococcus salivarius subsp. thermophilus produziram mais acetaldeído e diacetil que as outras de Streptococcus lactis homofermentativos, sendo que no meio contendo leite desnatado a proproção diacetil/acetaldeído foi de 0,3:1 e no meio MRS de 0,8:1. Em condições normais de 
processamento, a produção de acetaldeído foi maior para o leite de vaca (18 ppm) do que para os leites de cabra obtidos duas a três semanas após a parição e oito meses após a parição $(6,2$ a $8,9 \mathrm{ppm}$, respectivamente). Além disso, a produção de acetaldeído no leite de vaca ocorreu entre 2 a 5 horas de incubação e, após 8 horas nos dois tipos de leite de cabra. Estudos complementares avaliaram o efeito da adição de L-treonina e glicina na formação de acetaldeído no iogurte de leite de cabra. Conclui-se que níveis mais elevados de treonina, aumentaram a produção de acetaldeído sendo que esse efeito foi mais pronunciado no leite de cabra que no leite de vaca. Nos leites sem adição de treonina, a produção de acetaldeído foi significativamente maior no leite de vaca que no leite de cabra. A adição de glicina no leite de vaca produziu um efeito negativo sobre a cultura láctica na produção de acetaldeído. Quando adicionou-se $3 \mathrm{mg}$ glicina/100g de leite de vaca, houve produção de aproximadamente a mesma quantidade de acetaldeído também no leite de cabra. Isso sugere, para os autores, que a menor quantidade de acetaldeído, geralmente observada no iogurte de leite de cabra foi causada pela inibição do mecanismo de "feed-back" da treonina aldolase produzida pela maior quantidade de glicina livre no leite de cabra (Rysstad et al., 1987; Rysstad et al., 1990).

\subsubsection{Resfriamento pós-fermentação}

Esta etapa tem como objetivo reduzir a atividade metabólica da cultura láctica e assim controlar a atividade enzimática, evitando por exemplo, a acidificação excessiva do iogurte e portanto, a deterioração do produto, antes mesmo do vencimento do prazo de vida de prateleira. $\mathrm{O}$ resfriamento deve ser realizado quando o $\mathrm{pH}$ do iogurte atingir 4,6 ou a acidez estiver por volta de $0,9 \%$ de ácido láctico (Tamime et al., 1985). Para Araújo et al. (1993), o tempo de fermentação está relacionado diretamente com a temperatura de incubação, sendo necessário impedir a superacidificação e favorecer a formação de compostos aromáticos. Quando o produto atingir, após a fermentação, uma acidez de $72-76^{\circ} \mathrm{D}$ ou $\mathrm{pH} 4,7$ deve-se fazer o resfriamento rapidamente a temperatura de $18^{\circ} \mathrm{C}$, pois o desenvolvimento microbiano é interrompido e entre $5-12^{\circ} \mathrm{C}$ a atividade enzimática é profundamente afetada. Neirotti et al. (1988), utilizaram em seu experimento um resfriamento rápido com gelo até o coágulo atingir a temperatura de 
$7^{0} \mathrm{C}$ e para o armazenamento, $4^{\circ} \mathrm{C}$. De acordo com Tamime et al. (1985), o resfriamento deve ocorrer em duas etapas. Na primeira etapa, o coágulo é resfriado de 45 a $30^{\circ} \mathrm{C}$ para 20 a $15^{\circ} \mathrm{C}$, diretamente após o processo fermentativo, para que sejam adicionados flavorizantes e posteriormente haja a transferência do produto para os recipientes adequados. Na etapa seguinte, o iogurte é resfriado a temperaturas abaixo de $10^{\circ} \mathrm{C}$.

Para garantir a qualidade do iogurte após o processamento é necessário observar, que o principal agente deteriorador são as leveduras. Essa contaminação pode ocorrer depois do processamento, visto que estas são sensíveis ao calor. Portanto precisam ser corrigidas falhas na higienização de equipamentos ou contaminação por esporos do ar ambiente. As leveduras produzem $\mathrm{CO}_{2}$, etanol, e há aumento no $\mathrm{pH}$ durante a fermentação do iogurte (Brandão, 1995). Rohm et al. (1990), encontraram resultados que comprovam que o número de Streptococcus salivarius subsp. thermophilus e Lactobacillus delbrueckii subsp. bulgaricus permaneceu acima de $10^{8} \mathrm{ufc} / \mathrm{g}$ no iogurte armazenado a $10^{\circ} \mathrm{C}$ por $15-20$ dias após o processamento. A temperatura e o período de armazenamento reduziram a sobrevivência das bactérias das cultura láctica, porém a população de levedura aumentou de $10 \mathrm{ufc} / \mathrm{g}$ para $10^{6} \mathrm{ufc} / \mathrm{g}$.

Salji et al. (1983), avaliaram a variação da acidez titulável do iogurte durante o armazenamento, pois este atributo representa um dos maiores índices de aceitabilidade para os consumidores. Foram avaliadas as relações entre a acidez inicial do iogurte e as possíveis alterações durante o armazenamento. Os resultados indicaram que amostras com acidez inicial menores ( $\mathrm{pH}$ elevado) apresentaram aumento na acidez durante o armazenamento. Por outro lado, amostras com acidez inicial elevada (pH baixo) permaneceram constantes. Mudanças no $\mathrm{pH}$ durante o armazenamento foram mais notadas a $7^{\circ} \mathrm{C}$ do que a $4^{0} \mathrm{C}$.

\subsection{TEXTURA DO IOGURTE DE LEITE DE CABRA}

A textura do iogurte é tão importante quanto o "flavour'. Um iogurte de excelente qualidade deve apresentar consistência adequada, sem a separação do soro (Kroger, 1976). Entretanto, o leite de cabra difere dos outros tipos de leite pois a 
coalhada formada é semi-líquida. Caso não sejam feitas modificações, com o leite de cabra, não é possível preparar um iogurte com um grau de consistência semelhante ao leite de vaca (Kurmann et al., 1992).

Ould-Eleya et al. (1995), realizaram um estudo comparativo sobre a ação do pH e e da temperatura para a coagulação ácida dos leites de vaca, ovelha e cabra. Foi utilizado o método turbidimétrico, baseado na reflexão da luz e viscosimetria capilar. A acidificação direta dos diferentes tipos de leite, foi realizada com a adição de glucona- $\delta$ lactona. Constatou-se que apesar das diferenças na composição micelar da caseína e da concentração de minerais, os leites de vaca, ovelha e cabra, comportaram-se de modo semelhante durante a acidificação. Sobre o leite de cabra, observou-se que a 15 e $20^{\circ} \mathrm{C}$, o coágulo formado assemelhava-se a uma dispersão de partículas grosseiras ao invés de uma rede contínua; e que a temperaturas mais elevadas, os géis de leite de cabra formados, foram os mais fracos quando comparados ao leite de vaca e de ovelha.

Van Dender et al. (1990), com o objetivo de contornar o problema de baixa viscosidade do iogurte de leite de cabra e contribuir para as melhorias na preparação artesanal deste, estudou o uso de culturas produtoras de mucopolissacarídeos (filantes). Observou-se que com o aumento da proporção da cultura filante $(0 ; 1,5 ; 3,0 \%)$ houve aumento também nos valores de viscosidade $(185 ; 210 ; 260$ centipoise). O iogurte natural elaborado com culturas filantes se mostrou adequada para contornar o problema de baixa viscosidade, tornando-os mais viscosos e semelhante ao iogurte de leite de vaca. No entanto, sensorialmente, para os provadores não foram detectadas diferenças significativas em relação ao iogurte de leite de cabra elaborado com cultura filante e cultura não filante.

Kroger (1976), sugere que para a obtenção de uma textura adequada, pode-se aumentar o teor de sólidos do leite ou utilizar-se de agentes estabilizantes. Para promover o aumento da viscosidade do produto final, os estabilizantes são chamados mais corretamente, nesse caso, de espessantes (Furtado, 1997). 


\subsection{USO DE ESPESSANTES E A CORREÇÃO DO TEOR DE SÓLIDOS TOTAIS NO PROCESSAMENTO DO IOGURTE DE LEITE DE CABRA}

\subsubsection{Carragena}

A carragena é um polissacarídeo extraído da alga conhecida como musgo irlandês Chondrus crispus. Ela é encontrada na costa da Irlanda, Grã-Bretanha e França. As carragenas diferem entre si, em função do conteúdo dos grupos de 3,6-anidro-Dgalactose e do número e da posição dos grupos éster-sulfato. Todas as carragenas possuem uma estrutura comum composta por um polissacarídeo linear constituído de ligações alternadas 1,3 $\beta$-D-galactopiranosil e ligações 1,4 $\alpha$-D-galactopiranosil, contendo aproximadamente $18 \%$ de grupos éster sulfato. Os principais copolímeros da carragena são kappa-, iota- e lambda-carragena. As carragenas são solúveis em leite aquecido e possuem a habilidade de estabilizar efetivamente, as frações sensíveis ao cálcio como a caseína- $\alpha_{s}$ e a $\beta$-caseína. Dentre os colóides utilizados em produtos lácteos com pH neutro, as carragenas certamente são as mais indicadas pois ocorre reação com a caseína tanto em $\mathrm{pH}$ normal do leite $(\mathrm{pH} 6,7)$ quanto no ponto isoelétrico da caseína (pH 4,6) (Glicksman, 1983; Moirano, 1977; Syrbe et al., 1998; Whistler et al., 1985). Acima do ponto isoelétrico da proteína, íons metálicos polivalentes em solução formam pontes entre as cargas carregadas negativamente dos grupos carboxilícos da proteína e as cargas negativas dos grupos éster sulfato do polissacarídeo. Em pH abaixo do ponto isoelétrico da proteína, interações eletrostáticas semelhantes acontecem entre os grupos éster sulfato do polissacarídeo e os grupos aminos protonados da proteína (Lin, 1977). Entretanto para Syrbe et al. (1998), as carragenas são capazes de formar complexos com a caseína até mesmo em pH neutro. A formação do complexo da carragena, é particularmente forte com a $\mathrm{K}$-caseína, sem o envolvimento de cátions específicos, o que é explicada pela presença de cargas positivas na cadeia polipeptídica da $\kappa$-caseína. Entretanto, a complexação com a $\beta$-caseína e a caseína- $\alpha_{s 1}$ é também possível desde que haja íons cálcio e pHs acima de 6,0. Além do mais, apenas a kappa- e 
a iota-carragenas formam géis termoreversíveis. A temperatura de gelatinização e a força do gel dependem fortemente dos cátions presentes.

Xu et al. (1992), concluíram que a gelatinização da mistura א-carragena e leite de vaca envolve a interação da micela de caseína com apenas parte da molécula de carragena, permanecendo o restante da carragena livre para agregar-se posteriormente. Augustin et al. (1999b), estudaram a interação da א-carragena em função do solvente e da conformação do polissacarídeo com a micela de caseína do leite de vaca. O diâmetro médio das partículas na mistura dependem da composição iônica da $\kappa$-carragena, das soluções de leite diluída e da mistura final, ou seja, mistura de leite $(0,2 \mathrm{w} / \mathrm{w} \%)$ e $\kappa$ carragena $(0.004 \mathrm{w} / \mathrm{w} \%)$. Não houve mudanças no diâmetro das partículas nas soluções de carragena na água e leite em água, pois o polissacarídeo estava na conformação de espiral ao acaso. Foram observados os seguintes resultados após a pesquisa : o leite diluído adicionado de $\kappa$-carragena $(0.004 \mathrm{w} / \mathrm{w} \%)$ e 4 milimoles de $\mathrm{CaCl}_{2}$ apresentou um diâmetro médio de partícula maior que 250 nanômetros, após uma noite de armazenamento. Quando o leite foi adicionado de 80 milimoles de $\mathrm{KCl}$ e posteriormente solução de $\kappa$-carragena $(0.004$ w/w\%), o diâmetro da partícula foi maior que 290 nanômetros. Houve precipitação de partículas, quando o leite foi adicionado de 80 milimoles de $\mathrm{KCl}$ e 4 milimoles de $\mathrm{CaCl}_{2}$, juntamente com a solução de $\kappa$-carragena (0.004 w/w\%). Quando foi adicionado ao leite, 4 milimoles de $\mathrm{CaCl}_{2}$ juntamente com a solução de א-carragena $(0.004 \mathrm{w} / \mathrm{w} \%)$, observou-se após o armazenamento, que o diâmetro médio das partículas foi maior que os citados anteriormente, aproximadamente 350 nanômetros. Os autores concluíram que a gelatinização da $\kappa$-carragena ocorreu durante o resfriamento da solução. Houve uma mudança da carragena da forma espiral ao acaso para a conformação de hélice. E que esta fase de transição é mediada, principalmente, pelos íons cálcio, potássio e sódio. Realmente, os resultados mostraram que a conformação da carragena e as interações específicas envolvendo o íon cálcio, afetaram a interação com a micela de caseína e a formação de agregados. Payens (1972), avaliou a reatividade da carragena no leite de vaca em função de sua estabilidade no ultrafiltrado de leite frio. De modo geral, o polissacarídeo dissolveu completamente a 
altas temperaturas. Pode-se observar que houve opacidade da dispersão de $\kappa$-carragena em solução salina de leite em função da temperatura. Durante o resfriamento, o polissacarídeo tornou-se insolúvel novamente, formando ligações ao acaso entre suas moléculas e as da proteína. O ponto de geleificação, então correspondeu, a temperatura na qual houve número suficiente de ligações entre cadeias e a rede tridimensional foi formada primeiramente. Então esta interação ocorreu por atração eletrostática entre a carga negativa dos grupos sulfatos da carragena e a carga positiva na cadeia de peptídeos da א-caseína. Tziboula et al. (1999), sugerem que a א-carragena formou um complexo com as micelas de caseína e as proteínas do soro. Com as micelas de caseína houve uma forte interação que foi satisfeita primeiramente, reduzindo assim a disponibilidade da carragena para a gelatinização. Em concentrações elevadas de $\kappa$-carragena, predominaram os efeitos de gelatinização, prevalecendo o sistema de aprisionamento das micelas de caseína e os complexos de micela de caseína-carragena. Baixas concentrações de carragena formaram ligações cruzadas interhelicoidais entre as moléculas de carragena e o início do processo de agregação que levou a formação do gel.

Kalab et al. (1975), avaliaram os efeitos de três agentes espessantes sobre a microestrutura do iogurte de leite de vaca, utilizando-se de microscopia eletrônica de varredura e transmissão. Os espessantes utilizados foram a gelatina $(0,5 \%)$, carragena $(0,4 \%)$ e amido $(2 \%)$. A carragena formou uma microestrutura fibriliar ligando ramos das micelas de caseína. As fibras formadas eram finas e longas e não foram observadas a presença de terminações livres. Artignan et al. (1997), observaram que durante a fermentação do leite de vaca adicionado de carragena, o pH exerceu um efeito significativo sobre parâmetros como firmeza, coesão e porcentagem de deformação da ruptura do coágulo do leite. Outra descoberta foi que em leites com pHs baixos entre 6,5 a 5,5, houve formação de géis mais brilhantes. Tal fato pode ser associado a uma maior concentração de cálcio solúvel. A quantidade de carragena empregada no processamento do iogurte diverge de forma não muito significativa entre os autores consultados. 
A legislação brasileira para produtos lácteos, determina que a concentração de carragena permitida para ser utilizada em leites fermentados é de $5 \mathrm{~g} / \mathrm{kg}(0,5 \%)$ no produto final (Brasil, 1998).

\subsubsection{Pectina}

A pectina faz parte da estrutura da parede celular de plantas e é usada intensivamente como agente geleificante e estabilizante pela indústria de alimentos. Além do mais, a ingestão de alimentos ricos em pectina parece reduzir a taxa de colesterol sangüíneo em humanos (Christensen, 1983; Gutierrez, 1997; Nelson et al., 1977; Pasquel, 1999; Whistler et al., 1985). Fietz (1998), verificaram os efeitos de pectina cítrica e da celulose nos níveis séricos de colesterol e triglicerídeos em ratos hiperlipidêmicos. Foi observado que as dietas ricas em pectina cítrica foram as mais eficazes que as dietas a base de celulose, pois a primeira reduziu os níveis séricos de colesterol total, triglicerídeos e LDL e aumentou as concentrações plasmáticas de HDLcolesterol. A pectina comercial é considerada como uma cadeia contendo de 200 a 1000 unidades de ácido galacturônico unidos por ligações glicosídicas $\alpha-1,4$. Algumas das unidades de ácido galacturônico na molécula são esterificadas e estão presentes na forma de ésteres metílicos de ácido galacturônico. Os grupos ácidos restantes podem ser parcialmente ou completamente neutralizados por formar sais de amônia, potássio ou sódio. As pectinas são classificadas de acordo com o seu grau de esterificação, que é definido como a razão do número de unidades de ácido galacturônico esterificados pelo número de unidades de ácido galacturônico na molécula. As pectinas de alta metoxilação (HM="high metoxyl"), apresentam grau de esterificação acima de $50 \%$, exigem para geleificação um teor mínimo de açúcar e $\mathrm{pH}$ por volta de 3,0 . As pectinas de baixa metoxilação (LM="low metoxyl"), possuem grau de esterificação abaixo de $50 \%$ e geralmente são obtidas a partir de plantas que possuem pectina de alta metoxilação. Apresentam amplas faixas de $\mathrm{pH}$ para a formação do géis, embora exijam a presença de cálcio. Por essa razão, as pectinas de baixo grau de esterificação são as mais indicadas para a fabricação de produtos lácteos, assim como o iogurte tipo natural (Christensen, 1983; Gutierrez, 1997; Nelson et al., 1977; Pasquel, 1999; Whistler et al., 1985). 
A textura do iogurte pode ser melhorada por pequenas quantidades de pectina de baixa metoxilação adicionadas ao leite antes da pasteurização e fermentação e forma-se o gel com o cálcio presente no leite em pHs elevados. As pectinas de baixa metoxilação são utilizadas como agentes geleificantes em sobremesas lácteas. Diferente da carragena, a pectina não reage com a caseína no gel para formar o coágulo do queijo na interface onde o pH é reduzido pela difusão do íon hidrogênio (Christensen et al., 1983). Entretanto, Syrbe et al. (1998), citam que a pectina de baixa metoxilação apresenta numerosos grupos carboxílicos que deveriam estar mais fortemente ligados com as cargas positivas das partículas de caseína que as pectinas de alto grau de metoxilação.

Ramasmamy et al. (1990), avaliaram a influência da adição de pectina (0,0$0,5 \%)$ e concentrado de framboesa $\left(64^{0} \mathrm{~B} ; 0-10 \%\right)$ nas características reológicas de iogurtes de leite de vaca, tipo batido ("stirred"), de marcas comerciais. Concluíram então, que a adição de pectina a viscosidade aumentou e, que apresentou uma taxa de deformação mais estável enquanto a adição do concentrado aumentou também a viscosidade porém, de uma maneira bem menos estável. Os autores afirmam ainda que a reologia dos iogurtes flavorizados poderia ser melhor controlada com a adição de concentrações mais adequadas de pectina e concentrado. Basak et al. (1994) em estudos posteriores, encontraram que a concentração de pectina necessária para o aumento da viscosidade em iogurtes de leite de vaca do tipo batidos comerciais seria de 0,3 a $0,4 \%$ enquanto que com uma concentração de $10 \%$ de polpa de morango seria necessário 0,2 a $0,3 \%$ de pectina. No Brasil, a concentração de pectina utilizada na produção de leites fermentados é de $10 \mathrm{~g} / \mathrm{kg}$, ou seja, $1 \mathrm{~g} / 100 \mathrm{~g}$ (1\%) no produto final (Brasil, 1998).

\subsubsection{Leite em pó desnatado de vaca}

O teor de sólidos totais no leite é importante para a consistência e o aroma no preparo do iogurte. A porcentagem de sólidos totais é estabelecida por padrões legais de cada país. Normalmente, este teor varia de aproximadamente $9 \%$ no iogurte desnatado para acima de $20 \%$ em outros tipos de iogurte. Entretanto, a composição de sólidos totais da maioria dos iogurtes comerciais varia de 14-15\% (Tamime et al., 1980). 
Thomopoulus et al. (1993), avaliaram o processo de fortificação de sólidos totais do leite de vaca em relação ao tempo de coagulação e propriedades referentes a qualidade do iogurte. Foi estudada a influência dos tratamentos térmicos $95^{\circ} \mathrm{C}$ por 5 min comparado com o tratamento de $65^{\circ} \mathrm{C}$ por $15 \mathrm{~min}$, sobre a viscosidade aparente, medidas em viscosímetro de Brookfield, dos iogurtes integrais e desnatados, adicionados de leite em pó desnatado $(2,5 \%)$ e concentrado de proteína do leite $(0,5 \%)$. Os resultados apontaram que os leites desnatados fortificados, ou seja, que tiveram um aumento no teor de sólidos do leite, resultaram num aumento na viscosidade aparente destes iogurtes.

O principal efeito do aumento dos sólidos totais na formação do gel do leite acidificado é a redução nos valores de $\mathrm{pH}$, no início da geleificação do leite. Assim como a firmeza e a elasticidade do gel formado com a acidificação do leite aumentam com o aumento do teor de sólidos totais. Gastaldi et al. (1997), observaram que a agregação micelar ocorreu em $\mathrm{pH}$ acima de 5,8. A pH 5,5, as micelas de caseína começaram a se unir no tratamento com $20 \%$ de matéria seca enquanto o mesmo fato pode ser visto, no leite com $10 \%$ de matéria seca, porém em $\mathrm{pH} 5,8$. Em ambos os tratamentos, no $\mathrm{pH} \mathrm{5,3}$ as partículas de caseína estavam totalmente unidas. A solubilização do fosfato de cálcio coloidal foi provavelmente responsável por mudanças na composição da micela de caseína, capacidade tamponante, propriedades de microestrutura e ópticas naquela faixa de $\mathrm{pH}$.

Kehagias et al. (1989) estudaram os efeitos da adição de cloreto de cálcio, aumento do teor de gordura, de sólidos não-gordurosos e do teor de proteína nas propriedades físicas do iogurte de leite de cabra natural. Foram utilizados leites de cabra de três raças distintas : Indígena, Saanen e Saanen cruzada com espécies locais não citadas. Os autores observaram que houve correlação entre a força de penetração do iogurte com o teor de cálcio, gordura e sólidos não-gordurosos. Com o aumento na concentração de leite em pó desnatado, houve aumento na força de penetração do iogurte, enquanto a viscosidade permaneceu inalterada. Como conclusão, notou-se que a consistência foi melhor para o iogurte preparado com leite de cabra da raça indígena em 
relação aos iogurtes produzidos com os leites de cabra das outras espécies. O iogurte produzido com o leite de cabra da raça indígena foi comparado com os iogurtes de leite de vaca de marcas comerciais, visto que os consumidores não estavam acostumados a ingestão de iogurte de leite de cabra. Durante a avaliação sensorial, os provadores observaram que a consistência do iogurte de leite de cabra poderia ser melhorada, podendo ser corrigida através do ajuste de sólidos totais do leite.

Tamime et al. (1991), compararam a microestrutura e a firmeza do Labneh (iogurte com elevado teor de sólidos) feito a partir de leite de vaca, cabra e ovelha, utilizando-se o método tradicional, ou seja, por padronização do teor de sólidos totais adicionando-se leite em pó, ou por ultrafiltração. Observou-se que a firmeza do Labneh feito tradicionalmente com leite de ovelha (1422 milinewtons) foi próxima ao Labneh produzido por ultrafiltração com leite de vaca (1470 milinewtons), entretanto o Labneh produzido tradicionalmente com leite de cabra apresentou uma estrutura bem mais suave (256 milinewtons). O Labneh feito com leite de cabra foi também o menos uniforme quando comparado aos outros dois tipos de Labneh, pois apresentou amplos espaços vazios em sua estrutura, independente do processo de fabricação.

Moodler et al. (1983), concluíram que iogurtes preparados com caseína, leite em pó desnatado e concentrado protéico apresentaram alto grau de fusão da micela quando comparado a iogurtes estabilizados com concentrados de proteína do soro. Mistry et al. (1992), avaliaram o efeito do aumento do teor de proteínas no iogurte de leite de vaca desnatado. Os pesquisadores descobriram, através da microscopia eletrônica de varredura, que com o aumento do teor de proteína, a porosidade na estrutura do iogurte diminuiu. Além disso, os iogurtes desnatados com boa qualidade podiam ser produzidos com concentrado em pó com alto teor de proteína (acima de 5,6\%), ocasionando um corpo firme e separação mínima do soro.

\subsection{ANÁLISE SENSORIAL}

A análise sensorial é definida como uma disciplina científica usada para medir, analisar, interpretar reações das características dos alimentos e dos materiais, como são 
percebidas pelos órgãos da visão, olfato, tato, audição e gustação. Os pesquisadores buscam metodologias que viabilizem análises coerentes e que proporcionem delineamentos corretos e a interpretação adequada dos dados (Dutcosky, 1996).

A análise de perfil sensorial é um método que nos fornece informações qualitativas do alimento. Assim, novos métodos descritivos foram desenvolvidos a fim de se quantificar essas informações, dentre eles é citado o método de Análise Descritiva Quantitativa (Stone et al., 1974), o qual identifica, descreve e quantifica os atributos sensoriais do produto. A Análise Descritiva Quantitativa é uma ferramenta valiosa para aumentar a informação sobre a aparência, aroma, sabor e textura dos produtos, e é usada efetivamente para produtos e processos em desenvolvimento, estudos de prateleira e controle de qualidade dos alimentos (Gillete, 1984).

Normalmente 6 a 12 provadores são necessários para avaliação do produto através de métodos descritivos, após serem selecionados e treinados adequadamente (Chaves, 1990). Os métodos mais utilizados para selecionar os provadores são os testes de reconhecimento de gosto básicos e testes de diferença para determinar a habilidade em se detectar variações específicas do produto teste e fornecer resultados reprodutíveis (Mori, 1982).

Para formação da equipe de provadores, a exigência básica é o treinamento, para se obter um grupo com habilidade para descrever e perceber as características do produto, assim como discutir e definir os termos que melhor o descrevem (Lyon et al., 1992). Como o instrumento de medida é o ser humano, o treinamento é indispensável para que haja uma linguagem consensual de termos definidos pela equipe de provadores (Harper, 1984).

A qualidade do iogurte pode ser avaliada de duas maneiras: através de testes sensoriais ou análises de laboratório, com medidas físicas, químicas ou microbiológicas. As avaliações sensoriais são observadas sempre como um complemento das análises físico-químicas ou microbiológicas, pois determinam a aceitabilidade do produto no mercado consumidor e, portanto, sua viabilidade econômica. Existe alguma controvérsia sobre o sabor ideal do iogurte. O sabor depende inteiramente da cultura dos microrganismos e do seu metabolismo durante a incubação. Os odores e sabores 
estranhos podem geralmente estar associados aos sub-produtos da fermentação inadequada. Os principais defeitos no sabor são: ausência de "flavour"; sabor "verde", ou seja, quando a concentração de acetaldeído predomina sobre a concentração de diacetil; sabor metálico (oxidado); ranço; de levedura; desagradável; áspero por excesso de acidez produzida. A característica de sabor do iogurte é definida especialmente pela formação do ácido láctico, e traços de acetaldeído, diacetil e ácido acético. Os componentes originais do leite e suas concentrações também desempenham um papel importante, especialmente a gordura e os sólidos não-gordurosos. O desenvolvimento do gosto ácido e do sabor característico variam para cada tipo de iogurte. O iogurte se tornará sólido a uma acidez ao redor de $0,6 \%$ (expresso como \% de ácido láctico). Nesse ponto, o pH está ao redor de 5,3 dependendo do tipo de leite e do teor de proteína. $\mathrm{O}$ sabor amargo no iogurte pode ocorrer, principalmente, devido ao conteúdo de peptídeos formados pela atividade proteolítica dos lactobacilos durante o armazenamento, a qual está associada com a temperatura de incubação inadequada. Normalmente este problema não é detectado em culturas lácticas mantidas a temperaturas de 42 a $44^{\circ} \mathrm{C}$ (Kroger, 1976; Rash, 1990).

A consistência do iogurte é tão importante quanto o sabor. A firmeza adequada, sem sinérese é essencial à qualidade desejável do produto. A perda de textura pode ser indicativo de possíveis problemas ocorridos durante a fermentação. A adição de leite em pó pade contribuir para a melhoria na textura, assim como a presença de gordura do leite. Os espessantes também podem ser usados para obter um iogurte com corpo e textura desejados. Deve ser observado que, por exemplo, um $\mathrm{pH}$ final de 4,1 a 4,2 é considerado ótimo, entretanto, em um pH acima de 4,5 forma-se um coágulo fraco. Embora a temperatura de incubação seja geralmente $43^{\circ} \mathrm{C}$, um ligeiro decréscimo a 40$42^{\circ} \mathrm{C}$ irá resultar em melhor corpo dentro de um período de poucas horas de incubação. Pode-se fazer uso de espessantes para a manutenção do corpo do iogurte, porém a adição de algumas enzimas que promovam a coagulação do leite, possam levar à formação de textura granulosa. Certos espessantes como o amido modificado, carragena, alginato, carboximetilceluluose, entre outros, são exemplos de agentes que podem aumentar a consistência do iogurte. Esses espessantes podem ser utilizados isoladamente ou de 
forma associada. Quando usados de modo adequado, eles ocupam um importante papel no melhoramento do corpo e textura, assim como na aparência do iogurte. Um iogurte sem espessante torna-se mais vulnerável aos fatores de stress, como carregamento, oscilações de temperatura, etc. Alguns autores observaram que o coágulo formado pelo leite de cabra é mais frágil, macio e fino, quando comparado ao leite de vaca (Duitschaever, 1978; Fergusson \& Cooper, 1978).

Outros meios empregados para aumentar a viscosidade de leite de cabra fermentado, consistem no aumento do teor de sólidos totais (até 13,5\%), adicionando-se leite em pó ou na homogeneização do leite, que exigiria a utilização de equipamentos sofisticados (Ferguson \& Cooper, 1978).

A sinérese do iogurte é um defeito comum observado pelos provadores e é causada, entre outros fatores, pela quebra do coágulo devido ao manuseio impróprio, acidez e temperatura inadequadas, assim como o teor de proteína abaixo de $3,4 \%$; baixo teor de gordura; alto teor de mineral do leite; aquecimento insuficiente do leite e aquecimento do coágulo durante ou logo após a incubação (Kroger, 1976).

Alguns autores observaram o processo de fermentação do leite de cabra para a elaboração de iogurte natural, adicionado de xaropes de frutas. O leite sofreu um aquecimento térmico a $85^{\circ} \mathrm{C}$ durante 15 minutos e em seguida o resfriamento a $42^{\circ} \mathrm{C}$, sendo a seguir inoculado com cultura láctica (Streptococcus salivarius subsp. thermophillus e Lactobacillus delbureckii subsp. bulgaricus) e incubado $42^{\circ} \mathrm{C}$ por 3 horas. Os resultados da análise sensorial, obtidos pelos autores citados, para o iogurte natural, usando-se teste triangular, demonstraram que houve diferença significativa entre as amostras ao nível de $5 \%$ de probabilidade. Usando-se o teste de escala hedônica para verificar a aceitabilidade do iogurte natural de leite de cabra, constatou-se que a amostra em questão foi considerada muito boa, embora o iogurte realizado com leite de vaca fosse considerado melhor. Com relação aos produtos adicionados de xaropes, não houve diferença significativa ao nível de 5\% de probabilidade (Araújo et al., 1986).

Van Dender et al., (1990) estudaram o uso de culturas filantes, como técnica alternativa para tentar solucionar o problema da baixa viscosidade do iogurte de leite de cabra. A avaliação sensorial foi realizada através do teste de aceitabilidade com iogurtes 
de leite de cabra e de vaca, no qual os provadores avaliaram a textura e o sabor, assim como aceitabilidade geral. Estes autores observaram que a utilização de culturas filantes se mostraram bastante adequadas como alternativa para contornar o problema da baixa viscosidade do iogurte de leite de cabra. Tal prática deu origem a um iogurte natural integral mais viscoso e semelhante ao leite de vaca, melhorando assim, suas características sensoriais. As culturas não-filantes, por sua vez, apresentaram um produto menos consistente, mas não ao ponto de serem rejeitadas pelos provadores, tendo recebido médias referentes a gostei pouco na avaliação. De modo geral, não foi detectado qualquer sabor estranho referente ao leite de cabra, a não ser o fato de apresentar acidez mais alta em relação ao leite de vaca.

Manjunath et al. (1983), realizaram avaliação sensorial de iogurte natural de leite de cabra utilizando um painel composto por cinco membros que classificaram o iogurte a partir de uma escala arbitrária de 20 pontos. A nota média atribuída ao iogurte de leite de cabra foi 16 enquanto que para o iogurte controle preparado com leite de vaca foi 15 . Além disso, o "flavour" característico dos produtos a base de leite de cabra foi completamente mascarado pelo acetaldeído produzido pela cultura láctica do iogurte, apresentando um produto final com aroma suave. 


\section{MATERIAL E MÉTODOS}

\subsection{MATERIAL}

\subsubsection{Leite de Cabra}

Para o experimento foi coletado o leite cru integral de cabra fornecido pelo Departamento de Produção Animal da ESALQ/USP. As cabras pertenciam a raça Saanen e Parda Alpina e foram alimentadas com silagem de milho e concentrado.

\subsubsection{Fermento Láctico}

O fermento láctico, cujo nome comercial é "Rich", foi composto por cepas de Streptococcus salivarius subsp. thermophilus e Lactobacillus delbrueckii subsp. bulgaricus e foi fornecido pela CHR. Hansen Indústria e Companhia Ltda.

\subsubsection{Carragena}

A carragena utilizada, tipo Seakem GP 418, foi fornecida pela FMC do Brasil.

\subsubsection{Pectina}

A pectina utilizada, de baixa metoxilação e do tipo 8002 , foi fornecida pela Braspectina S/A.

\subsubsection{Leite em pó desnatado de vaca}

O leite em pó utilizado foi o leite de vaca desnatado, da marca comercial Molico.

\subsection{PROCESSAMENTO}

O leite cru integral de cabra foi primeiramente aquecido à temperatura de 32 $33^{\circ} \mathrm{C}$ para posterior desnate, seguindo a recomendação expressa no manual da 
desnatadeira elétrica Elecrem. O teor de gordura do leite de cabra foi padronizado para $0,1 \%$, transformando-se portanto em um leite desnatado.

Após a análise de gordura, foi realizada a análise de densidade, para que pudesse ser feita, em um dos tratamentos, a correção do teor de sólidos totais para $14 \%$, préestabelecida em ensaios preliminares.

Os doze litros de leite de cabra iniciais, após o desnate foram reduzidos para oito litros e posteriormente fracionados em quatro béqueres de dois litros. Antes do tratamento térmico, no béquer 1 foi adicionada a mistura carragena $0,1 \%$ e pectina $0,1 \%$, pré-estabelecida anteriormente; no béquer 2 foi adicionado $0,5 \%$ de pectina, sendo que em ambos os espessantes foram dissolvidos completamente por agitação prévia em liquidificador por 3 minutos; no béquer 3 , o leite em pó desnatado de vaca (aproximadamente $5 \%$ ) e no béquer 4 , a testemunha, ou seja, apenas o leite de cabra desnatado.

A utilização da carragena $0,1 \%$ associada à pectina $0,1 \%$ foi sugerida pelo fabricante porque em ensaios preliminares não foi possível formular um iogurte de leite de cabra com as características desejadas usando apenas a carragena.

Então, os béqueres foram colocados em um banho-maria até alcançarem a temperatura de $80^{\circ} \mathrm{C}$ e mantidos a esta temperatura por um tempo de $30 \mathrm{~min}$, sempre sob agitação.

Terminado o tempo do tratamento térmico, os béqueres com os quatro tratamentos foram resfriados em água gelada. Quando a temperatura do leite de cabra chegou a $42^{\circ} \mathrm{C}$ foi realizada a etapa de incubação com a adição do fermento láctico, composto pelo Streptococcus salivarius subsp. thermophilus e Lactobacillus delbrueckii subsp. bulgaricus. Em câmara de fluxo laminar, os leites foram inoculados com 3\% de cultura láctica reativada, cuja concentração foi pré-estabelecida em ensaios preliminares. Os leites de cabra com o inóculo dos quatro tratamentos foram divididos em frascos de polietileno para que a fermentação ocorresse no próprio recipiente. 
Os potes foram levados para uma estufa pré-aquecida à $42-43^{\circ} \mathrm{C}$ onde ocorreu o processo de fermentação por aproximadamente 3 horas, ou seja, para que o $\mathrm{pH}$ atingisse a escala de 4,6. Em seguida procedeu-se o resfriamento, primeiramente de $42-30^{\circ} \mathrm{C}$ e depois a $20-15^{\circ} \mathrm{C}$ e finalmente a $10^{\circ} \mathrm{C}$. Após o resfriamento dos iogurtes de leite de cabra, uma parcela dos iogurtes correspondente a cada tratamento proposto foi reservada em refrigerador a temperatura controlada de $4^{0} \mathrm{C}$, por um período de armazenamento de cinco dias, para que no quinto dia fosse realizada a Análise Sensorial. Foi levado em consideração esse prazo, porque dentro deste período de armazenamento ocorreu a ação efetiva dos espessantes sobre os iogurtes, de acordo com a recomendação do fabricante (dois dias após a fabricação), assim como para intensificar as características peculiares desejáveis aos iogurtes. Outra parte dos iogurtes referente aos quatro tratamentos, foi congelada a $-18^{\circ} \mathrm{C}$, para que as análises químicas fossem feitas em outro período por dois motivos importantes: primeiro, há sazonalidade na produção do leite de cabra, podendo haver períodos de entressafra; segundo, que em virtude da total disponibilidade de tempo para o preparo e a realização da Análise Sensorial, tornou-se inviável a realização das análises químicas dos iogurtes de leite de cabra concomitantemente. Portanto, a realização das análises químicas dos iogurtes de leite de cabra foram realizadas no primeiro e no quinto dia após o descongelamento das amostras, em períodos alternados a realização da Análise Sensorial.

\subsection{MÉTODOS}

O experimento foi conduzido no Setor de Laticínios, do Departamento de Agroindústria, Alimentos e Nutrição, da Escola Superior de Agricultura "Luiz de Queiroz" - ESALQ - USP. Foram processados iogurtes de leite de cabra adicionados da mistura carragena $0,1 \%$ e pectina $0,1 \%$; pectina $0,5 \%$; leite em pó desnatado de vaca $\mathrm{e}$ a testemunha.

Foram avaliados os efeitos dos tratamentos nas características químicas e sensoriais do iogurte de leite de cabra. 


\subsubsection{Análises Físico-Químicas do Leite de Cabra Desnatado}

As análises do leite de cabra desnatado foram feitas em triplicata e no dia da coleta do leite.

\subsubsection{Determinação da densidade}

A densidade do leite de cabra foi determinada a $15^{\circ} \mathrm{C}$, segundo Laboratório Nacional de Referência Animal (1981).

\subsubsection{Determinação do pH}

A determinação dos valores de $\mathrm{pH}$ do leite de cabra foi realizada segundo Brasil (1980), em pHmetro, da marca Digimed, Mod. DMPH-2.

\subsubsection{Determinação da acidez titulável}

A acidez titulável foi determinada através da titulação do leite de cabra com hidróxido de sódio 0,111 mol/L S.V. (Dornic), de acordo com a A.O.A.C. (1995). Cada $0,1 \mathrm{~mL}$ corresponde a $1^{0} \mathrm{D}$ e cada $1^{0} \mathrm{D}$ corresponde a $0,01 \%$ de acidez expressa em ácido láctico.

\subsubsection{Determinação da gordura}

$\mathrm{O}$ teor de gordura do leite foi determinado pelo método de Babcock, de acordo com Newlander \& Atherton (1964).

$$
\text { \%gordura=Leitura } \times 2
$$

\subsubsection{Determinação do extrato seco total (EST)}

O teor de extrato seco total foi determinado segundo A.O.A.C., (1995). O cálculo foi feito pela seguinte fórmula:

$$
\text { EST } \%=100-\% \text { umidade }
$$




\subsubsection{Determinação de proteína total}

A determinação de proteína total do leite foi avaliada pelo método de Kjeldahl, segundo A.O.A.C. (1995).

O cálculo do teor percentual de nitrogênio total por meio da fórmula abaixo:

$$
\% \mathrm{NT}=\_(\mathrm{A}-\mathrm{B}) \times \mathrm{Ci} \times \mathrm{fc} \times 1,4
$$

$\mathrm{mL}$

onde:

\%NT: teor percentual de nitrogênio total $(\mathrm{m} / \mathrm{v})$;

A: volume gasto na titulação da amostra;

B: volume gasto na titulação da prova em branco;

Ci: concentração (mol/L) da solução de ácido clorídrico;

Fc: fator de correção para a solução de ácido clorídrico; e

$\mathrm{ML}$ : volume de amostra, considerando-se a diluição efetuada $(0,25 \mathrm{~mL})$.

$$
\% \mathrm{~PB}=\% \mathrm{NT} \times 6,38
$$

onde:

\%PB: teor de proteína bruta

\subsubsection{Teor de Resíduo Mineral Fixo (Cinzas)}

A determinação do resíduo mineral fixo do leite de cabra foi realizado segundo A.O.A.C. (1995). O cálculo foi feito seguindo a fórmula abaixo:

$$
\% \mathrm{RMF}=\frac{\mathrm{Pf}-\mathrm{T}}{\mathrm{Pi}-\mathrm{T}} \times 100 \%
$$

onde:

\%RMF: teor de resíduo mineral fixo (cinzas), em \% (m/m);

Pf: resultado da última pesagem; 
Pi: resultado da pesagem inicial, (cadinho + amostra) e;

T: tara do cadinho de porcelana.

\subsubsection{Análises Químicas dos Iogurtes de Leite de Cabra Desnatados}

As análises químicas dos iogurtes de leite de cabra foram realizadas em dois períodos distintos, no primeiro dia e no quinto dia após o descongelamento das amostras e em triplicata.

\subsubsection{Determinação do $\mathrm{pH}$}

A determinação dos valores de $\mathrm{pH}$ dos iogurtes de leite de cabra foi realizada segundo Brasil (1980), em pHmetro, da marca Digimed, Mod. DMPH-2.

\subsubsection{Determinação da acidez titulável}

A acidez titulável foi determinada através da titulação dos iogurtes de leite de cabra com hidróxido de sódio 0,111 mol/L S.V. (Dornic), de acordo com a A.O.A.C. (1995). Cada $0,1 \mathrm{~mL}$ corresponde a $1^{0} \mathrm{D}$ e cada $1^{0} \mathrm{D}$ corresponde a $0,01 \%$ de acidez expressa em ácido láctico.

\subsubsection{Determinação do extrato seco total (EST)}

O teor de extrato seco total dos iogurtes de leite de cabra foi determinado, segundo A.O.A.C., (1995). O cálculo foi feito pela seguinte fórmula:

EST $\%=100-\%$ umidade

\subsubsection{Determinação de proteína total}

A determinação de proteína total dos iogurtes de leite cabra foi avaliada pelo método de Kjeldahl, segundo A.O.A.C. (1995). 
O cálculo do teor percentual de nitrogênio total por meio da fórmula abaixo:

$$
\% \mathrm{NT}=(\mathrm{A}-\mathrm{B}) \times \mathrm{Ci} \times \mathrm{fc} \times 1,4
$$

$\mathrm{mL}$

onde:

\%NT: teor percentual de nitrogênio total $(\mathrm{m} / \mathrm{v})$;

A: volume gasto na titulação da amostra;

B: volume gasto na titulação da prova em branco;

Ci: concentração (mol/L) da solução de ácido clorídrico;

Fc: fator de correção para a solução de ácido clorídrico; e

ML: volume de amostra, considerando-se a diluição efetuada $(0,25 \mathrm{~mL})$.

$$
\% \mathrm{~PB}=\% \mathrm{NT} \times 6,38
$$

onde:

\%PB: teor de proteína bruta

\subsubsection{Análise Sensorial}

A análise sensorial foi realizada aplicando-se métodos discriminativos para seleção de provadores e método descritivo para medir a qualidade dos iogurtes de leite de cabra. As análises foram realizadas em duas estapas distintas: seleção e treinamento de provadores e avaliação sensorial da qualidade dos iogurtes de leite de cabra, através da Análise Descritiva Quantitativa (ADQ), (Stone et al., 1974).

\subsubsection{Recrutamento e seleção da equipe de provadores}

Para realizar o recrutamento de provadores, levou-se em consideração a disponibilidade de tempo do provador, assim como sua habilidade na percepção das diferenças nos atributos de aparência, sabor e textura do produto.

As análises sensoriais foram realizadas no laboratório do Departamento de Agroindústria, Alimentos e Nutrição da ESALQ/USP em salas com cabines apropriadas, com controle de temperatura e iluminação. A equipe de provadores foi composta por 3 
homens e 7 mulheres, na faixa etária de 20 a 40 anos, constituindo-se de técnicos e estudantes de mestrado do Departamento. Os testes de seleção e treinamento de provadores foram realizados em duas etapas distintas: teste de reconhecimento de sabores e teste de sensitividade para gosto.

\subsection{Teste de reconhecimento de sabores}

Esse teste foi realizado empregando-se soluções quimicamente puras para análise de gostos básicos: doce (sacarose 0,14\%); ácido (ácido cítrico 0,07\%); salgado (cloreto de sódio $0,5 \%$ ) e amargo (cafeína $0,7 \%$ ). Essas soluções foram colocadas em copos plásticos descartáveis, numerados aleatoriamente com algarismos de três dígitos e foi oferecida água potável para que os provadores utilizassem entre as análises (Fisher et al., 1971).

Essa fase de seleção, assim como as demais, foi realizada em uma sala apropriada para análise sensorial que dispunha de temperatura controlada, cabines individualizadas, bandejas com as amostras, água potável, fichas de avaliação, lápis, borracha, guardanapo de papel, visando obter a diferenciação entre os sabores básicos. Nessa etapa de seleção, nenhum provador foi excluído, apresentando $100 \%$ de acerto (Figura 2).

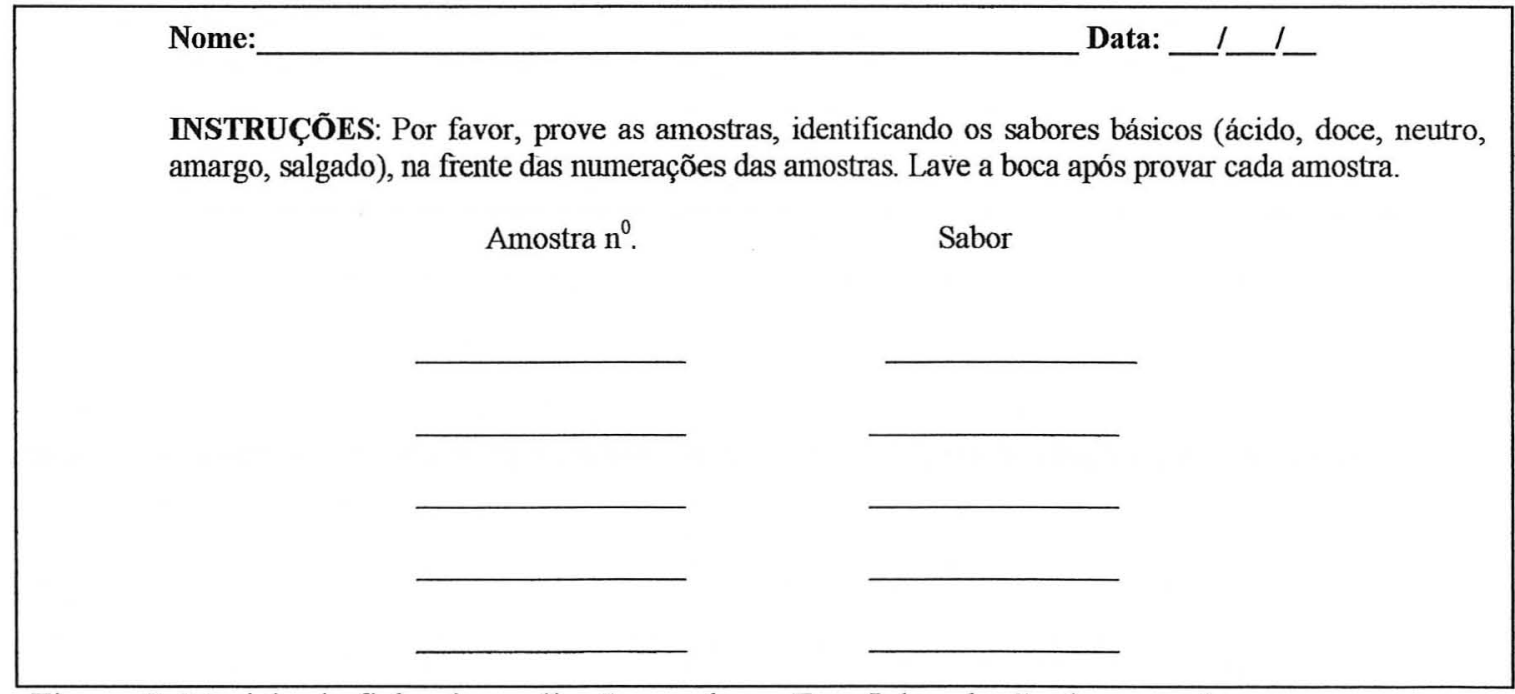

Figura 2. Modelo de ficha de avaliação usada na Fase I da seleção de provadores 


\subsection{Teste de sensitividade para gosto}

Esse teste foi realizado empregando-se o Teste Triangular (Helm \& Trolle, 1946; Garruti, 1976), utilizando-se como amostras, os iogurtes de leite de cabra sem espessante, com os espessantes pectina e carrragena e iogurte de leite de vaca. As amostras eram apresentadas duas a duas, e o provador era solicitado a identificar a diferença existente entre elas.

A seleção final dos provadores foi realizada a partir dos resultados de nove testes triangulares com aplicação de análise senqüencial (Wald, 1947; Steiner, 1966), com os seguintes valores de probabilidade $P_{0}=1 / 3 ; P_{1}=2 / 3 ; \alpha=0,05$ e $\beta=0,10$, onde $P_{0}=$ máxima habilidade inaceitável; $\alpha=$ probabilidade de se rejeitar um provador aceitável; $\beta=$ probabilidade de se selecionar um provador rejeitável e $\mathrm{P}_{1}=$ mínima habilidade aceitável (Figura 3).

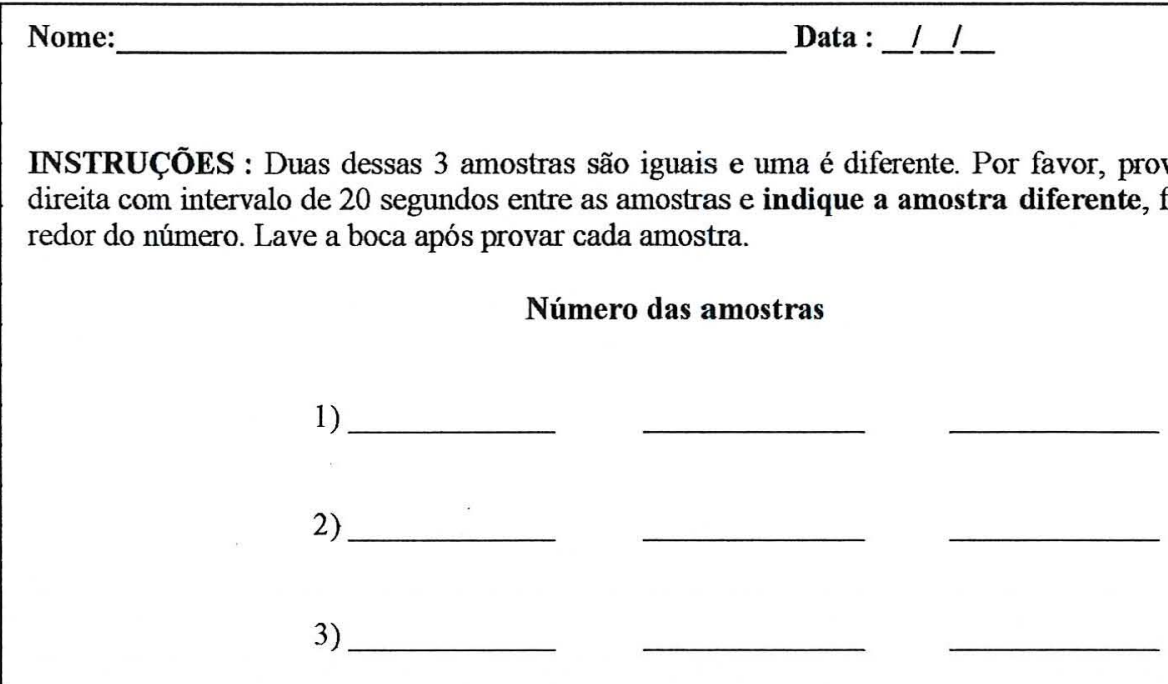

Figura 3. Modelo da ficha de avaliação usada na Fase II da seleção de provadores

\subsection{Treinamento}

Após a seleção dos provadores, procedeu-se a fase de treinamento, a qual constou de uma preleção aos provadores pelo supervisor, tendo por objetivo a escolha de uma terminologia descritiva na identificação dos atributos sensoriais dos iogurtes de 
leite de cabra. Durante as sessões de treinamento foram levantados as mais variáveis características, completando-se a Análise de Perfil de Atributos dos iogurtes de leite de cabra. Nessa fase foram oferecidos os próprios tratamentos aos pares e pedido para que fosse feita a identificação das diferenças e semelhanças entre os iogurtes, através do Método de Rede (Dutcosky, 1996). Vários atributos foram levantados pelo provadores, os quais constam na Figura 4.

\section{APARÊNCIA}

Cor: 0 branco (leite de cabra pasteurizado)

10 amarelado (iogurte natural desnatado "firme" da marca Danone e gema de ovo)

Brilho: 0 opaco (creme de maizena grosso)

10 brilhante (gelatina)

Consistência: 0 líquido (leite de vaca HTST)

10 consistente (iogurte natural desnatado "firme" da marca Danone)

Viscosidade: 0 fluído (leite de vaca HTST)

10 viscoso (mel)

Presença de Grânulos: 0 poucos grânulos ( bebida láctea com mel da marca Danone)

TEXTURA

10 muitos grânulos (bebida láctea com mel da marca Danone adicionada de ricota)

Consistência: 0 líquido (leite de vaca HTST)

10 consistente (iogurte natural desnatado "firme" da marca Danone)

Viscosidade: 0 fluído (leite de vaca HTST)

10 viscoso (mel)

Presença de Grânulos: 0 poucos grânulos ( bebida láctea com mel da marca Danone)

SABOR

10 muitos grânulos (bebida láctea com mel da marca Danone adicionada de ricota)

Ácido: 0 pouco ácido (leite de vaca HTST)

10 muito ácido (iogurte natural desnatado "firme" da marca Danone $+0,07 \%$ de ácido láctico)

Doce: 0 pouco doce (iogurte natural desnatado "firme" da marca Danone)

10 muito doce (iogurte natural desnatado "firme" da marca Danone $+0,14 \%$ de sacarose)

Salgado: 0 pouco salgado (iogurte natural desnatado "firme" da marca Danone)

10 muito salgado (iogurte natural desnatado "firme" da marca Danone $+0,5 \%$ de cloreto de sódio)

Amargo: 0 pouco amargo (iogurte natural desnatado "firme" da marca Danone)

10 muito amargo (iogurte natural desnatado "firme" da marca Danone $+0,07 \%$ de cafeína)

Característico: 0 pouco característico

10 muito característico (iogurte natural desnatado "firme" da marca Danone)

Impressão Global: 0 péssimo

10 excelente (iogurte natural desnatado "firme" da marca Danone)

Figura 4. Lista de definições dos termos descritivos para os atributos de aparência, textura e sabor e as respectivas referências utilizadas durante o treinamento e avaliação dos iogurtes de leite de cabra desnatados submetido a diferentes processamentos 
A avaliação sensorial dos tratamentos para o experimento foi realizada observando-se as mesmas condições obedecidas anteriormente. Os iogurtes de leite de cabra desnatados foram analisados à temperatura de $4^{0} \mathrm{C}$, após cinco dias de armazenamento. Entre as análises foi oferecida água para a lavagem dos palatos e oferecidos brindes de agradecimento no final de cada avaliação.

Os atributos selecionados foram avaliados através da Análise Descritiva Quantitativa (ADQ), (Stone et al., 1974). Para a medida da intensidade de cada atributo, foi utilizada uma escala não estruturada de 0 a 10 , ancorada nas extremidades com notas de 1 e 9 (Figura 5).

Nome: Data: 1

Por favor, avalie cada um dos atributos abaixo, indicando com um traço vertical, o ponto da escala que melhor quantifique a intensidade de cada atributo.

APARENCIA

Cor

Amostra branco amarelado

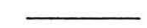
1 1

Brilho

Amostra opaco brilhante Consistência

Amostra líquido consistente

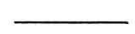
$+$ |

Presença de Grânulos Amostra poucos grânulos muitos grânulos
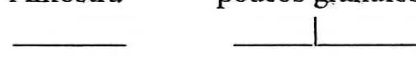

.

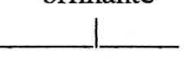




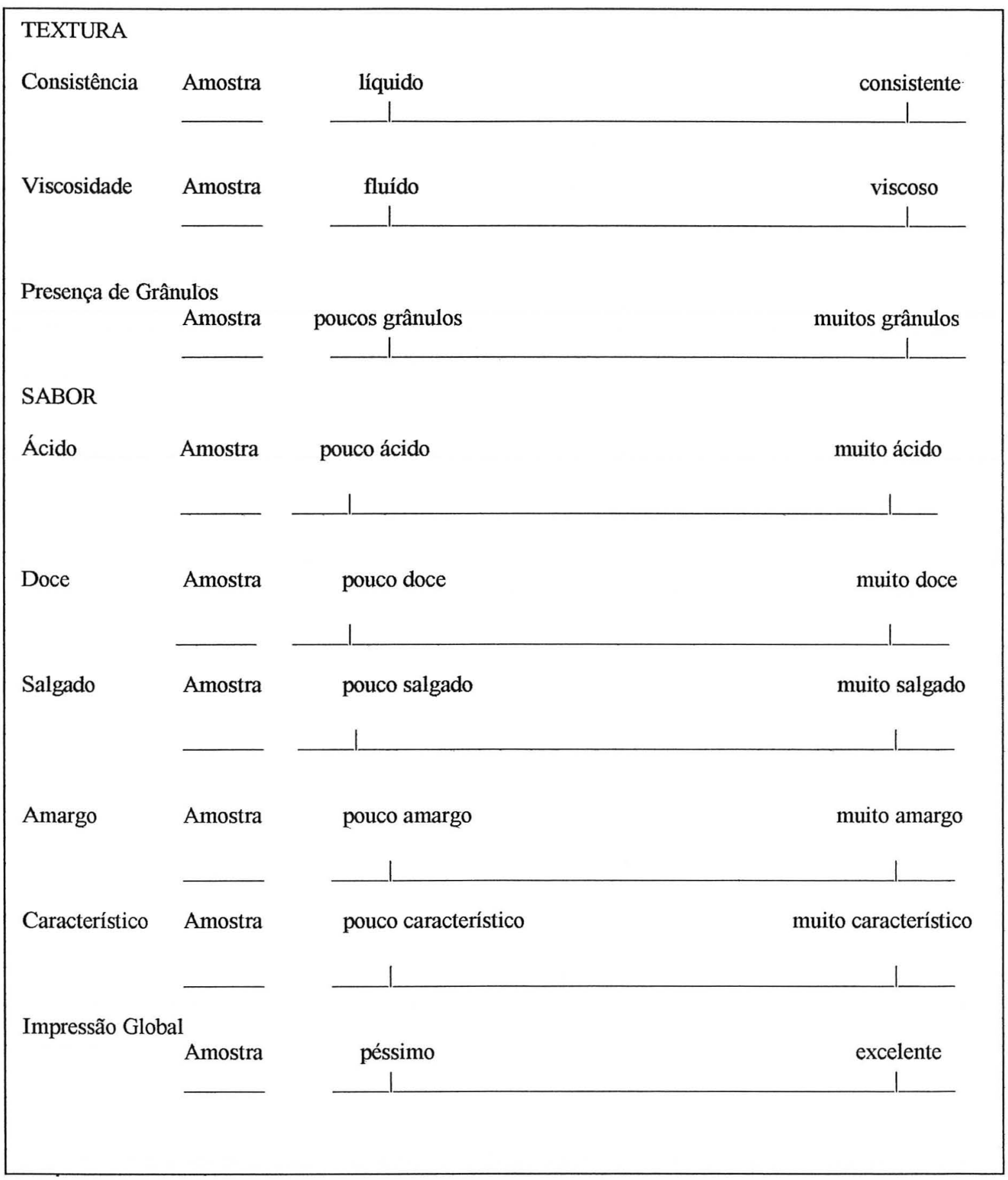

Figura 5. Modelo da ficha de avaliação da Análise Sensorial dos tratamentos 


\subsubsection{Análise Estatística}

O delineamento experimental, empregado na análise química foi em blocos ao acaso com os fatores dispostos no esquema fatorial $4 \times 2$, referentes a 4 níveis de tratamento (1=iogurte de leite de cabra com carragena/pectina $0,1 \% ; 2=$ iogurte de leite de cabra pectina $0,5 \% ; 3=$ iogurte de leite de cabra leite em pó desnatado; $4=$ iogurte de leite de cabra) e 2 níveis de períodos de armazenamento ( 1 e 5 dias), constituindo cada combinação em bloco, num total de 5 blocos completos.

$\mathrm{Na}$ análise sensorial foi utilizado o delineamento experimental em blocos ao acaso, constituindo cada provador um bloco, num total de 10 blocos com um único fator com quatro níveis (tratamentos $1,2,3$ e 4).

Os resultados obtidos foram submetidos à análise de variância, com aplicação do teste F. A análise estatística teve continuidade com o teste de Tukey, quando o teste $\mathrm{F}$ foi significativo ao nível de $5 \%$.

Todas as análises foram realizadas em microcomputador utilizando-se o programa estatístico Sas (1989). 


\section{RESULTADOS E DISCUSSÃO}

\subsection{MATÉRIA-PRIMA}

A caracterização da composição média do leite de cabra desnatado utilizado no processamento do iogurte pode ser observada na tabela abaixo:

Tabela 1. Valores médios da composição físico-química do leite de cabra desnatado

\begin{tabular}{lc}
\hline \multicolumn{1}{c}{ Parâmetros Físico-Químicos } & Valores Médios \\
\hline $\mathrm{pH}$ & 6,66 \\
Acidez Titulável ( $\left.{ }^{0} \mathrm{D}\right)$ & 18,12 \\
Gordura (\%) & 0,1 \\
Extrato Seco Total (\%) & 9,45 \\
Proteína (\%) & 3,39 \\
Cinza (\%) & 0,91 \\
Densidade & 1,033 \\
\hline
\end{tabular}

A partir dos resultados avaliados (Tabela 1), pode-se observar, que o valor de $\mathrm{pH}$ encontrado para o leite de cabra neste experimento, 6,66, foi bem próximo ao encontrado por Gomes et al. (1997), 6,62. Entretanto, o valor de pH encontrado neste trabalho foi maior quando comparado a Araújo et al. (1986), que observaram um valor de $\mathrm{pH}$ igual a 6,59.

Em relação à acidez titulável, Anifantakis \& Kandarakis (1980), apresentaram uma faixa de 12 a $16^{\circ} \mathrm{D}$ tendo como valor médio de $14^{\circ} \mathrm{D}$ para o leite de cabra. Esse 
valor está de acordo com Gomes et al. (1997) que encontraram um valor médio de $14,6^{\circ} \mathrm{D}$. Entretanto o valor encontrado neste experimento, $18,15^{\circ} \mathrm{D}$ foi maior do que os autores citados acima, porém mais próximo ao encontrado por Araújo et al. (1986) igual a $18^{\circ} \mathrm{D}$ sendo portanto considerado dentro dos valores estabelecidos pela legislação para o leite de cabra entre 13 e $18^{0} \mathrm{D}$ (Brasil, 1999).

Os teores de extrato seco total do leite de cabra encontrados por Anifantakis \& Kandarakis (1980) e Gomes et al. (1997) foram respectivamente 11,13\% e 11,03\%, diferentes do que foi observado neste trabalho, sendo o valor médio de 9,45\%. Essa diferença ocorreu porque o leite de cabra utilizado na fabricação do iogurte foi previamente desnatado, implicando diretamente na redução do teor de extrato seco total deste leite. O desnate do leite de cabra foi necessário para que o "odor de bode" acentuado no leite e nos derivados fosse reduzido. Este odor está relacionado aos ácidos graxos livres liberados durante a ordenha (Jandal, 1996).

O valor médio de proteína total encontrado neste trabalho, $3,40 \%$ foi maior quando comparado ao encontrado por Ould-Eleya et al. (1995), 2,87\% e menor em relação a Araújo et al. (1986), apresentando valor igual a 4,16\%. Entretanto, o teor de proteína total do leite de cabra deste experimento está de acordo com Anifantakis \& Kandarakis (1980), que citaram o teor de proteína entre 2,86-3,54\%.

O teor médio de cinzas para o leite de cabra, encontrado neste trabalho, $0,80 \%$ esteve de acordo com os valores citados por Anifantakis \& Kandarakis (1980), 0,80\% e bem próximo ao citado por Araújo et al. (1986), 0,84\%. 
Para a densidade, o valor médio obtido para o leite de cabra neste experimento foi de 1,0335 abaixo do valor encontrado por Araújo et al. (1986), 1,0360 e acima do valor citado por Anifantakis \& Kandarakis (1980) e Gomes et al. (1997), igual a 1,0300.

A composição do leite fresco pode sofrer alterações diariamente devido a vários fatores como sistema de criação, estágio de lactação, idade do animal, saúde ou infecção do úbere, a alimentação, condições climáticas, estação do ano e até mesmo os intervalos entre as ordenhas (Tamime et al., 1985). Todos esses fatores podem interferir diretamente nas características e na qualidade do iogurte a ser processado.

\subsection{ANÁLISES QUÍMICAS DOS IOGURTES DE LEITE DE CABRA DESNATADOS}

Os iogurtes de leite de cabra desnatados adicionados da mistura carragena $0,1 \% \mathrm{e}$ pectina $0,1 \%$; pectina $0,5 \%$; leite em pó desnatado de vaca, cujo teor de sólidos totais foi corrigido para aproximadamente $14 \%$ e a testemunha foram submetidos à análises químicas de $\mathrm{pH}$, acidez titulável, extrato seco total e proteína total no primeiro e no quinto dia após o descongelamento dos iogurtes. Esse curto período de armazenamento foi determinado visto que a ação dos espessantes sobre os iogurtes de leite de cabra já poderia ser avaliada após o segundo dia de armazenamento. 
Tabela 2. Valor de F, obtido da análise de variância, para algumas características químicas dos iogurtes de leite de cabra desnatados submetidos a diferentes processamentos.

\begin{tabular}{cccccc}
\hline C.V. & G.L. & \multicolumn{5}{c}{ Valor F } \\
\cline { 3 - 6 } & & $\mathrm{pH}$ & Acidez Titulável & Proteína Total & Extrato Seco Total \\
\hline Tratamento & 3 & $6,53^{*}$ & $12,56^{*}$ & $157,89^{*}$ & $89,61^{*}$ \\
$(\mathrm{~T})$ & & & & & \\
Período (P) & 1 & $1,61 \mathrm{~ns}$ & $0,19 \mathrm{~ns}$ & $6,11^{*}$ & $3,45 \mathrm{~ns}$ \\
T x P & 3 & $0,17 \mathrm{~ns}$ & $0,74 \mathrm{~ns}$ & $0,60 \mathrm{~ns}$ & $1,31 \mathrm{~ns}$ \\
Bloco & 4 & - & - & - & - \\
Resíduo & 28 & - & - & - & - \\
\hline Total & 39 & - & - & - & - \\
\hline
\end{tabular}

Observou-se pelo teste $\mathrm{F}(\mathrm{p}<0,05)$ que houve efeito do tratamento sobre todos os parâmetros avaliados : $\mathrm{pH}$, acidez titulável, proteína total e extrato seco total; efeito de período de armazenamento somente sobre o teor de proteína total e não houve efeito da interação em nenhum dos parâmetros (Tabela 3). Pode-se concluir portanto, que o período de armazenamento não exerceu influência em nenhum dos tratamentos analisados. 
Tabela 3. Médias e desvio padrão dos valores de $\mathrm{pH}$, acidez titulável, proteína total e extrato seco total dos iogurtes de leite de cabra desnatados submetidos diferentes processamentos.

\begin{tabular}{ccccc}
\hline & \multicolumn{3}{c}{ Valores Médios } \\
\cline { 2 - 5 } Tratamentos & $\mathrm{pH}$ & $\begin{array}{c}\text { Acidez Titulável } \\
\left({ }^{0} \mathrm{D}\right)\end{array}$ & $\begin{array}{c}\text { Proteína Total } \\
(\%)\end{array}$ & $\begin{array}{c}\text { Extrato Seco } \\
\text { Total }(\%)\end{array}$ \\
\hline Carragena/Pectina & $4,19 \pm 0,02 \mathrm{a}$ & $109,90 \pm 4,45 \mathrm{a}$ & $3,02 \pm 0,10 \mathrm{a}$ & $7,96 \pm 0,38 \mathrm{a}$ \\
$0,1 \%(1)$ & & & & \\
Pectina 0,5\% (2) & $4,22 \pm 0,03 \mathrm{a}$ & $106,22 \pm 4,66 \mathrm{a}$ & $3,10 \pm 0,11 \mathrm{a}$ & $8,00 \pm 0,22 \mathrm{a}$ \\
Leite em Pó (3) & $4,31 \pm 0,02 \mathrm{~b}$ & $135,54 \pm 3,91 \mathrm{~b}$ & $5,26 \pm 0,09 \mathrm{~b}$ & $14,15 \pm 0,25 \mathrm{~b}$ \\
Testemunha (4) & $4,20 \pm 0,02 \mathrm{a}$ & $107,27 \pm 3,18 \mathrm{a}$ & $2,85 \pm 0,11 \mathrm{a}$ & $7,93 \pm 0,41 \mathrm{a}$ \\
\hline
\end{tabular}

A partir dos resultados obtidos para os iogurtes de leite de cabra desnatados após cinco dias de armazenamento, observou-se que o iogurte de leite de cabra desnatado adicionado de leite em pó desnatado de vaca diferiu dos demais tratamentos, apresentando os maiores valores de $\mathrm{pH}$, acidez titulável, proteína total e extrato seco total (Tabela 3). A nova legislação para produtos lácteos, aponta que os valores de acidez para os leites fermentados está na faixa de 0,6 a 2,0 g de ácido láctico/100g ou 60 a $200^{\circ} \mathrm{D}$, sendo assim os valores de acidez titulável encontrados neste experimento em todos os tratamentos, estiveram de acordo com a legislação vigente para iogurtes de leite de vaca desnatados. Em relação ao teor de proteínas lácteas, o valor mínimo permitido para iogurtes desnatados é de $2,9 \%$, estando também de acordo com os valores deste trabalho (Brasil, 1998). Estes valores foram utilizados, visto que não há uma legislação brasileira específica para produtos a base de leite de cabra. Com a adição de leite em pó desnatado de vaca ao leite de cabra desnatado para a produção de iogurte houve aumento do teor do extrato seco total e do teor de proteína total deste iogurte em comparação aos 
demais tratamentos. Para os valores de $\mathrm{pH}$ e acidez titulável, houve um ligeiro aumento do $\mathrm{pH}$, enquanto a acidez titulável aumentou consideravelmente comparando-se aos outros tratamentos. Wolfschoon-Pombo et al. (1983), também observaram que com a adição de leite em pó de vaca ao leite de vaca integral utilizado para o preparo de iogurte, houve um nítido aumento na acidez titulável enquanto que o pH não aumentou de forma significativa. Por exemplo, o iogurte adicionado de $5 \%$ de sólidos no leite, obteve os valores de acidez titulável aumentados de 1,08 para $1,20 \mathrm{~g}$ de ácido láctico/100g de leite após sete dias de armazenamento, enquanto o $\mathrm{pH}$ variou de 4,63 para 4,37. Possivelmente, com o aumento no teor de sólidos totais do leite ocorreu uma modificação na relação pH-acidez titulável dos iogurtes pelo aumento da capacidade tamponante da mistura. Esse efeito tampão pode ter acontecido pela ação das proteínas, fosfatos, citratos, lactatos e outros componentes presentes no leite (Brandão, 1995; Tamime et al., 1985). Becker \& Puhan (1989), estudaram o efeito de pós-acidificação de iogurtes preparados com leite integral e leite desnatado, ambos de vaca, adicionados de leite em pó desnatado; ou que sofreram processo de evaporação ou que foram submetidos a ultrafiltração, armazenados por um período de 14 dias a $4^{0} \mathrm{C}$. Observou-se que no início do armazenamento, o $\mathrm{pH}$ do iogurte preparado com leite integral esteve entre 4,15 e 4,11 e para o iogurte preparado com leite desnatado, entre 4,14 e 4,12. O pH do iogurte de leite integral diminuiu durante o armazenamento, a $4^{0} \mathrm{C}$, porém com menor intensidade quando comparado ao iogurte preparado com leite desnatado. $\mathrm{O}$ efeito de pós-acidificação nos iogurtes preparados com leite ultrafiltrado foi menor visto que, devido à maior concentração de proteína, houve maior efeito tamponante no produto. Laye et al. (1993), observaram através da microscopia eletrônica de varredura e 
transmissão, que os iogurtes de leite de vaca preparados com leite em pó desnatado e concentrado protéico apresentaram cadeias de micelas de caseína mais unidas e com ligações mais curtas, ou seja, formando uma estrutura mais compacta e menos sujeita à sinérese.

\subsection{ANÁLISE SENSORIAL}

Os atributos avaliados na Análise Sensorial dos quatro iogurtes de leite de cabra fabricados englobaram a aparência, a textura, o sabor e a impressão global. Os dados foram submetidos às análises de variância e constatou-se pelo teste $\mathrm{F}$ que, para os atributos de aparência (cor, consistência e presença de grânulos), assim como a textura (consistência, viscosidade e presença de grânulos) e para o sabor (amargo, doce, característico e impressão global) houve diferença significativa $(\mathrm{p}<0,05 \%)$ entre os tratamentos (Anexos 20, 21, 22 e 23).

Tabela 4. Notas médias dos atributos de aparência cor, consistência e presença de grânulos e teste de Tukey dos iogurtes de leite de cabra desnatados submetidos a diferentes processamentos.

\begin{tabular}{cccc}
\hline Tratamentos & \multicolumn{3}{c}{ Notas médias dos atributos de aparência } \\
\hline & Cor & Consistência & Presença de Grânulos \\
\hline Carragena /Pectina & $2,25 \mathrm{a}$ & $3,21 \mathrm{a}$ & $3,66 \mathrm{a}$ \\
$0,1 \%(1)$ & & & \\
Pectina 0,5\%(2) & $2,98 \mathrm{~b}$ & $7,57 \mathrm{~b}$ & $5,37 \mathrm{~b}$ \\
Leite em pó(3) & $3,02 \mathrm{~b}$ & $7,33 \mathrm{a}$ & $5,04 \mathrm{ab}$ \\
Testemunha(4) & $2,14 \mathrm{a}$ & $4,22 \mathrm{c}$ & $4,75 \mathrm{ab}$ \\
\hline
\end{tabular}

Médias seguidas de letras distintas entre si ao nível de $5 \%$ DMS cor $=0,61$ consistência $=0,97$ DMS presença de grânulos $=1,48$ 
$\mathrm{O}$ atributo de cor foi avaliado pelos provadores, em escala de 0 a 10 , variando de branco a amarelado, respectivamente. Observa-se pela tabela 4, que o iogurte de leite de cabra desnatado adicionado da mistura carragena $0,1 \%$ e pectina $0,1 \%$ diferiu do iogurte de leite de cabra desnatado adicionado de $0,5 \%$ de pectina e do iogurte de leite cabra desnatado adicionado de leite em pó desnatado de vaca, sendo que o primeiro não diferiu da testemunha que obteve a menor para esse atributo. Os tratamentos 2 e 3 , segundo os provadores, receberam as maiores notas para o atributo cor, indicando que estes apresentaram uma coloração mais intensa tendendo para a amarelada, em relação aos demais tratamentos.

Com relação à presença da pectina, observou-se que o espessante comercial apresentava cor amarela, pois esta havia sido extraída da laranja. De acordo com Furtado (1997), as pectinas se localizam principalmente em tecidos pouco rijos como o albedo de frutas cítricas e polpa de beterraba. Chitara (1979), acrescenta que tanto no flavedo quanto no albedo ou na polpa há presença de carotenóides que conferem à fruta a coloração alaranjada.

Da mesma forma, o leite em pó desnatado de origem bovina apresenta caroteno que confere ao leite de vaca a coloração amarelada, além do mesmo ter sido adicionado de vitamina A. Por esta razão, como no leite de cabra, tais carotenóides estão ausentes, o mesmo apresenta uma coloração branca quando comparado ao leite de vaca (Jandal, 1996). Isso foi confirmado pelos provadores que apontaram a testemunha (iogurte de leite de cabra) como o tratamento que obteve uma coloração mais próxima a branca quando comparada aos demais tratamentos. O leite durante o processo de desidratação para a produção de leite em pó está sujeito a sofrer a Reação de Maillard, uma reação 
complexa envolvendo um açúcar (no caso, a galactose) com aminoácidos (principalmente a lisina) formando compostos intermediários, furfural e aldeídos, e finalmente levando à formação de melanoidinas, as quais conferem ao leite em pó uma coloração amarelada mais intensa que anteriormente ao início do processamento (Furtado, 1991). Pizzoferrato et al. (1998), avaliaram o efeito da reação de Maillard em alimentos a base de leite; constatou-se que a indisponibilidade da lisina ("lisina bloqueada") variou amplamente entre alimentos como leite condensado, 36,2\% e iogurte tipo mousse, aproximadamente $2,4 \%$. Essa diferença é afetada diretamente por fatores como o teor de proteína, os níveis de açúcares redutores e a intensidade do tratamento térmico. Este último fator altera consideravelmente a biodisponibilidade da lisina, como por exemplo, foi observado com o leite condensado, por isso foi mais intenso o efeito da reação de Maillard, neste produto. O iogurte tipo mousse não sofreu um tratamento térmico severo durante o processamento e portanto o aminoácido lisina esteve mais biodisponível. 
Tabela 5. Notas médias dos atributos de textura consistência, viscosidade e presença de grânulos e Teste de Tukey dos iogurtes de leite de cabra desnatados submetidos a diferentes processamentos.

\begin{tabular}{cccc}
\hline Tratamentos & \multicolumn{3}{c}{ Notas médias dos atributos de textura } \\
\hline & Consistência & Viscosidade & Presença de Grânulos \\
\hline Carragena /Pectina & $2,65 \mathrm{a}$ & $3,72 \mathrm{a}$ & $3,08 \mathrm{a}$ \\
$0,1 \%(1)$ & & & \\
Pectina 0,5\%(2) & $7,64 \mathrm{~b}$ & $5,74 \mathrm{~b}$ & $4,36 \mathrm{a}$ \\
Leite em pó(3) & $6,89 \mathrm{~b}$ & $5,88 \mathrm{~b}$ & $3,84 \mathrm{ab}$ \\
Testemunha(4) & $3,87 \mathrm{c}$ & $4,02 \mathrm{a}$ & $4,53 \mathrm{~b}$ \\
\hline
\end{tabular}

Médias seguidas de letras distintas entre si ao nível de $5 \%$ DMS consistência $=0,90$ DMS viscosidade $=$ 1,05 DMS presença de grânulos $=1,42$

Para a aparência em relação ao atributo consistência, o iogurte de leite de cabra desnatado adicionado da mistura carragena $0,1, \%$ e pectina $0,1 \%$ não diferiu da testemunha enquanto estes diferiram dos demais tratamentos que não diferiram entre si (Tabela 4). Para a textura, o atributo de consistência, o iogurte de leite de cabra desnatado adicionado de pectina $0,5 \%$ não diferiu do iogurte de leite cabra desnatado adicionado de leite em pó desnatado de vaca, porém, diferiram dos outros tratamentos, que da mesma forma diferiram entre si (Tabela 5).

$\mathrm{O}$ iogurte de leite de cabra desnatado associado à pectina $0,5 \%$ foi o que apresentou a maior nota para os atributos de consistência para a aparência e a textura, 7,57 e 7,64, respectivamente. Basak et al. (1994), apontaram que a concentração ótima de pectina para ser utilizada em iogurtes de leite de vaca sem a adição de polpa de fruta seria de 0,3 a $0,4 \%$. Entretanto, como não há uma legislação vigente específica para produtos derivados de leite de cabra, em ensaios preliminares foi determinado que a melhor concentração em termos de características mais próximas as ideais para este iogurte seria de $0,5 \%$. De acordo com os provadores, a consistência deste iogurte ficou semelhante a um pudim ou flan, ou seja, mais consistente que os demais iogurtes deste experimento. Brummel et al. (1990), avaliaram a ação de hidrocolóides solúveis em 
queijos cremosos que sofreram redução no teor de gordura. Foi observado que o aumento na concentração da pectina proporcionou um aumento na firmeza relativa do queijo cremoso. $\mathrm{O}$ cálcio no queijo cremoso pode ter formado fortes ligações quelantes intermoleculares com os grupos carboxílicos das moléculas de pectina contribuindo para o aumento da firmeza (Glicksman, 1985). O iogurte de leite de cabra desnatado adicionado de leite em pó desnatado, da mesma forma que o tratamento anterior, apresentou a segunda maior nota para consistência tanto para aparência quanto para a textura, respectivamente, 7,33 e 6,89. Com a adição de leite em pó desnatado houve um aumento no teor de sólidos totais, de $9,45 \%$ para $14,15 \%$ e no teor de proteína total, de $3,40 \%$ para 5,32\% (Tabela 3, 4 e 5). O aumento no teor de proteína total, proporcionou uma redução da porosidade na estrutura do iogurte produzido a partir de leite desnatado conferindo ao produto final um corpo firme e mínima separação de soro. $\mathrm{O}$ aumento no teor de sólidos totais influiu diretamente nas propriedades físicas do iogurte provocando um aumento nos valores de consistência e viscosidade (Mistry et al., 1992). Modler et al. (1983), confirmam que os iogurtes adicionados de leite em pó desnatado e de concentrado protéico apresentaram a microestrutura composta por cadeias de micelas de caseína unidas por ligações curtas. Becker et al. (1989), estudaram o efeito do aumento no teor de sólidos sobre a firmeza do coágulo formado, do leite de vaca desnatado adicionado de leite em pó desnatado, leite evaporado e leite ultrafiltrado. $\mathrm{O}$ teor de sólidos não-gordurosos do leite variou de $9,3 \%, 9,6 \%$ e 10,3\%. Verificou-se, entre todos os iogurtes testados, que o iogurte mais firme foi o iogurte preparado com leite ultrafiltrado com maior teor de sólidos não-gordurosos (10,3\%). Segundo Tamime et al. (1985), o melhor iogurte seria produzido com leite apresentando de 15 a 16\% de sólidos totais, porém comercialmente, os iogurtes tem $14-15 \%$ de sólidos totais. Observou-se também que os iogurtes de leite de cabra adicionados da mistura carragena $0,1 \%$ e pectina $0,1 \%$ e a testemunha foram os que apresentaram menor teor de sólidos totais e de proteína total, respectivamente, $7,96 \%$ e $3,15 \% ; 7,93 \%$ e $2,90 \%$ e que como conseqüência apresentaram os menores valores de consistência (Tabela 3).

Quanto a viscosidade, os iogurtes de leite de cabra desnatados adicionados da mistura carragena $0,1 \%$ e pectina $0,1 \%$ e a testemunha não diferiram entre si, mas 
diferiram dos iogurtes de leite de cabra desnatados adicionados de pectina $0,5 \%$ e de leite em pó desnatado de vaca, os quais não diferiram entre si. As maiores notas para a viscosidade foram atribuídas, segundo os provadores, aos iogurtes de leite de cabra desnatado adicionado de leite em pó desnatado de vaca e ao adicionado de pectina $0,5 \%$, 5,88 e 5,74, respectivamente (Tabela 5).

No processo de fabricação de iogurte e queijo, o pH do leite é diminuído pela fermentação ácido-láctica. Por causa do aumento no teor de sólidos totais há correção na textura e melhoria nas qualidades sensoriais dos produtos de leites cultivados, e a fortificação do leite adicionado de leite em pó desnatado ou concentrado protéico é comum (Tamime et al., 1980).

Wolfschoon-Pombo et al. (1983), estudaram o efeito do aumento do teor de sólidos totais (adição de 1\%, 2\%, 3\%, 4\% e 5\% de leite em pó) sobre a viscosidade do iogurte de leite de vaca. Concluiu-se que com o aumento no teor de sólidos totais do leite, por exemplo de $12,15 \%$ para $16,70 \%$, houve aumento na viscosidade proporcionalmente de 223,5 centipoise para 364,5 centipoise, 24 horas após a fabricação do iogurte. E que uma maior desnaturação das proteínas do soro no leite, não conduziram obrigatoriamente à maior viscosidade, porque os iogurtes elaborados com $4 \%$ e $5 \%$ de leite em pó apresentaram menores valores de desnaturação das proteínas do soro, entretanto, obtiveram os maiores valores de viscosidade. Thomopoulos et al. (1993), observaram o processamento do leite fortificado sobre o tempo de coagulação e as propriedades do iogurte. $\mathrm{O}$ aumento no teor de sólidos do leite pela adição de leite em pó desnatado resultou num aumento da viscosidade aparente. O leite desnatado adicionado de $2,5 \%$ de leite em pó desnatado teve um aumento considerável na viscosidade aparente de 1100 centipoise $\left(65^{\circ} \mathrm{C} / 15 \mathrm{~min}\right)$ para 1500 centipoise $\left(95^{\circ}\right.$ $15 \mathrm{~min})$.

Pasquel (1999), afirma que as pectinas funcionam como agentes geleificantes e espessantes em uma grande variedade de produtos. A adição de elevadas concentrações de pectina metoxilada previne a sedimentação das partículas de caseína. Entretanto, o mecanismo de interação entre a pectina e a caseína ainda não está completamente compreendido (Amice-Quemeneur et al., 1995). Basak et al. (1994), observaram que 
para o iogurte batido, o aumento na concentração de pectina de $0,0 \%$ para $0,5 \%$ proporcionou um aumento na viscosidade aparente do produto de $0,03 \mathrm{Pascal} / \mathrm{seg}$ para 0,13 Pascal/seg. O mesmo resultado foi observado sensorialmente neste experimento, para o iogurte de leite de cabra desnatado adicionado de pectina $0,5 \%$, pois este foi um iogurte bem aceito, em relação a viscosidade, pelos provadores, juntamente com o tratamento 3 .

Géis de leite desnatado acidificado foram homogeneizados e diluídos para obter bebidas lácticas líquidas de muito baixa viscosidade. Na ausência de pectina, a suspensão coloidal das partículas de caseína apresentou-se instável e houve separação da coalhada após poucas horas de fabricação para bebidas lácticas fermentadas com cultura láctica e acidificada diretamente. Como conseqüência, houve sinérese por causa da agregação e subseqüente sedimentação das partículas de caseína. Para os dois tipos de bebidas lácticas, com a adição de $0,4 \%$ de pectina, as bebidas permaneceram estáveis e não houve sinérese por várias semanas de armazenamento e também ocorreu aumento na viscosidade aparente. Possivelmente, o aumento na viscosidade das duas bebidas lácticas possa ter ocorrido por aumento no tamanho das partículas de caseína e então uma fina camada de pectina pode ter ficado adsorvida em suas superfícies (Amice-Quemeneur et al., 1995)

A testemunha foi o tratamento que recebeu a segunda menor nota para o atributo viscosidade, 4,02. Ould-Eleya et al. (1995), avaliaram a influência do $\mathrm{pH}$ e da temperatura sobre a coagulação dos leites de vaca, cabra e ovelha. $\mathrm{O}$ estudo apontou que a coagulação do leite de cabra a $15^{\circ} \mathrm{C}$ e $20^{\circ} \mathrm{C}$ foi composta por partículas grosseiras, ao invés de uma rede contínua e que este tratamento porém, com temperaturas mais elevadas formou géis de leite de cabra mais frágeis quando comparados aos géis de leites de vaca e ovelha.

$\mathrm{O}$ iogurte de leite de cabra desnatado adicionado da mistura carragena $0,1 \%$ e pectina $0,1 \%$ foi o tratamento que obteve a menor nota para a viscosidade, 3,72 . Como foi observado anteriormente, esse tratamento apresentou baixos teores de proteína total e extrato seco total (Tabela 3), e isso influenciou diretamente na viscosidade do iogurte. Langerdoff et al. (1997), observaram que em concentrações de carragena abaixo de 
0,1\%, o sistema (leite e carragena) apresentou-se líquido e instável pela formação de pequenas cadeias de carragena agregadas e parcialmente cobertas por micelas de caseína. A mistura carragena $0,1 \%$ e pectina $0,1 \%$ foi sugerida pelo fabricante da carragena, visto que, em ensaios preliminares não foi possível obter um iogurte com qualidade desejável, utilizando apenas o espessante carragena. Porém, a sugestão do fabricante da carragena foi estabelecida a partir de iogurtes preparados com leite de vaca. Para o leite de cabra desnatado, a concentração da mistura não foi satisfatória para o iogurte de leite de cabra natural, principalmente para os atributos de consistência e viscosidade.

Considerando-se o atributo de aparência presença de grânulos, o iogurte de leite de cabra desnatado adicionado da mistura carragena $0,1 \%$ e pectina $0,1 \%$ diferiu do iogurte de leite de cabra desnatado adicionado de pectina $0,5 \%$, porém não diferiu do iogurte de leite de cabra desnatado adicionado de leite em pó desnatado de vaca, e muito menos da testemunha (Tabela 4). A menor nota para a presença de grânulos foi verificada para o iogurte de leite de cabra desnatado adicionado da mistura carragena $0,1 \%$ e pectina $0,1 \%, 3,66$ enquanto, a maior nota foi atribuída ao iogurte de leite de cabra desnatado adicionado de pectina $0,5 \%, 5,37$. Para a presença de grânulos da textura, o iogurte de leite de cabra desnatado adicionado da mistura carragena $0,1 \% \mathrm{e}$ pectina $0,1 \%$ não diferiu do iogurte de leite de cabra desnatado adicionado de leite em pó desnatado de vaca, mas diferiu do iogurte de leite de cabra desnatado adicionado de pectina $0,5 \%$ e da testemunha, sendo que estes dois últimos tratamentos não diferiram entre si (Tabela 5). A menor nota foi atribuída para o iogurte de leite de cabra desnatado adicionado da mistura carragena $0,1 \%$ e pectina $0,1 \%, 3,08$ e a maior nota foi para a testemunha, 4,53. Tanto na aparência como na textura, os provadores consideraram o iogurte de leite de cabra desnatado adicionado da mistura carragena $0,1 \%$ e pectina $0,1 \%$ com pouca presença de grânulos, ou seja, mais homogênea em relação aos demais tratamentos, sendo a presença de grânulos considerada um defeito indesejável para a qualidade do iogurte (Kroger, 1976). Em relação ao iogurte de leite de cabra desnatado adicionado de pectina $0,5 \%$, os provadores detectaram a presença de grânulos em ambas características (aparência e textura). A presença de grânulos foi maior para a testemunha 
na textura. Christensen (1983), cita que podem ter ocorrido problemas na dissolução parcial do hidrocolóide (pectina), que não foram detectados durante o processamento dos iogurtes, porém os provadores indicaram que tanto no atributo de aparência quanto na textura, foi detectada a maior presença de grânulos no iogurte de leite de cabra desnatado adicionado de pectina. Outra possibilidade pode estar relacionada com a baixa produção de ácido láctico, baixas temperaturas de incubação, perturbações mecânicas durante a incubação quando o $\mathrm{pH}$ esteve próximo ao ponto isoelétrico da caseína (Souza, 1996). Todos esses fatores podem ter favorecido o aparecimento de grânulos nos iogurtes de leite de cabra desnatados adicionados de pectina $0,5 \%$ e na testemunha porque afetam diretamente a formação do coágulo do iogurte.

Tabela 6. Notas médias dos atributos de sabor amargo, doce, característico e impressão global dos iogurtes de leite de cabra desnatados submetidos a diferentes processamentos.

\section{Tratamentos}

Notas médias dos atributos de sabor e impressão global

\begin{tabular}{ccccc}
\hline & Amargo & Doce & Característico & Impressão Global \\
\hline Carragena/Pectina & $3,37 \mathrm{a}$ & $2,49 \mathrm{a}$ & $4,80 \mathrm{a}$ & $5,30 \mathrm{a}$ \\
$0,1 \%(1)$ & & & \\
Pectina 0,5\% (2) & $4,52 \mathrm{~b}$ & $2,39 \mathrm{a}$ & $4,71 \mathrm{a}$ & $4,83 \mathrm{a}$ \\
Leite em Pó (3) & $2,50 \mathrm{a}$ & $3,80 \mathrm{~b}$ & $6,27 \mathrm{~b}$ & $6,68 \mathrm{~b}$ \\
Testemunha (4) & $3,23 \mathrm{a}$ & $2,63 \mathrm{a}$ & $5,19 \mathrm{a}$ & $5,51 \mathrm{a}$
\end{tabular}

Médias seguidas de letras distintas entre si ao nivel de 5\% DMS amargo $=0,91$. DMS doce $=0,75$ DMS característico $=1,06 \%$ DMS impressão global $=0,76$

Em relação ao atributo de sabor amargo, verificou-se que o iogurte de leite de cabra desnatado adicionado de pectina $0,5 \%$ diferiu dos demais tratamentos, sendo que estes não diferiram entre si. $\mathrm{O}$ iogurte de leite de cabra desnatado adicionado de pectina $0,5 \%$ foi o tratamento que obteve a maior nota para o atributo amargo, 4,52. Portanto, este iogurte foi apontado pelos provadores, como o mais amargo entre todos os outros iogurtes avaliados. O sabor amargo atribuído ao iogurte de leite de cabra desnatado adicionado de pectina $0,5 \%$ pode ter origem no fato de que a pectina utilizada neste 
experimento foi extraída da laranja. Spoto (1993), avaliou os componentes químicos relacionados com o sabor e o aroma do suco de laranja. Foi observada na pectina a presença de quatro aldeídos: octanal, nonanal, decanal e dodecanal que conferiram ao suco de laranja, o sabor e o aroma característico, embora implicassem em um sabor mais amargo ao produto. Isso foi confirmado portanto, pelos provadores treinados que foram capazes de identificar esta particularidade na produção da pectina e que proporcionou a este iogurte um sabor mais amargo que para os demais iogurtes.

Para o atributo de sabor doce, o iogurte de leite de cabra desnatado adicionado de leite em pó desnatado de vaca diferiu dos demais tratamentos, sendo que estes não diferiram entre si. $\mathrm{O}$ iogurte de leite de cabra desnatado adicionado de leite em pó desnatado de vaca obteve a maior nota para o atributo doce, 3,80 .

Becker et al. (1989) realizaram um experimento com leite de vaca desnatado que teve o teor de sólidos não-gordurosos ajustados para 9,3\%, 9,6\% e 10,3\% para a fabricação de iogurte. $\mathrm{Na}$ análise sensorial, os provadores escolheram o iogurte que possuía o maior teor de sólidos não-gordurosos pois este iogurte apresentou características sensoriais diferenciadas.

Durante a fermentação há degradação da lactose, (o açúcar em maior concentração no leite) e devido a fortificação deste iogurte de leite de cabra desnatado adicionado de leite de pó desnatado de vaca, houve aumento de galactose no meio (Toba et al., 1983; Tamime et al., 1985). O maior teor de galactose presente neste tratamento, quando comparado aos outros tratamentos, provavelmente foram responsáveis por acentuar o sabor adocicado deste iogurte. Gutierrez (1997), cita que a lactose apresenta um grau de doçura relativa equivalente a 16. Entretanto, quando a lactose é hidrolisada à glicose e galactose, esta última dobra o poder adoçante para 32, portanto o sabor doce foi mais perceptível no iogurte de leite de cabra desnatado adicionado de leite em pó desnatado de vaca.

Para o atributo característico, foi dado aos provadores, como padrão, o iogurte natural de consistência firme comercial da marca Danone, visto que tal comparação não poderia ter ocorrido de outra forma, pois o iogurte de leite de cabra quando produzido, é distribuído apenas em caráter regional. $\mathrm{O}$ iogurte firme é obtido quando a fermentação e 
a coagulação do leite realiza-se na própria embalagem de comercialização (Tamime et al., 1980). O corpo do iogurte deve ser firme, viscoso, coeso para que o produto possa ser removido de seu recipiente e consumido usando uma colher. Quanto à consistência e a textura, deve ser suave, livre de grumos e não se apresentando com fissuras. A firmeza adequada, sem que haja separação do soro é essencial para a qualidade máxima do produto sendo que uma das técnicas utilizadas para se obter uma boa textura e consistência é corrigir o teor de sólidos (Penna et al., 1994). Souza (1996), afirma que o leite utilizado para a fabricação de iogurte não pode ter menos que $8,4 \%$ e não mais que 16\% desses sólidos. Entretanto, as diferenças de consistência são muito pequenas para os teores entre $16 \%$ e $20 \%$ de sólidos (Tamime et al., 1985). Ainda de acordo com Souza (1996), o iogurte deve apresentar viscosidade relativamente alta e conferir sensação macia e agradável no palato.

Em relação ao sabor e aroma, o iogurte tem que apresentar um nítido sabor ácido, devido a produção de ácido láctico que não apresenta odor próprio e quantidades pequenas de acetaldeído (principalmente), diacetil e ácido acético (Penna et al., 1994; Souza, 1996).

Conforme a Análise Sensorial realizada, o iogurte de leite de cabra desnatado adicionado de leite em pó desnatado apresentou as maiores notas para os atributos cor e viscosidade, sendo considerado o mais doce para o atributo de sabor. Foi a segunda melhor nota para o atributo de consistência tanto na aparência quanto na textura e foi também a segunda menor nota para a presença de grânulos com relação à textura. Conhecendo as características ideais de um iogurte natural, o iogurte de leite de cabra desnatado adicionado de leite em pó desnatado de vaca obteve as maiores notas para o atributo característico, 6,68 e por conseqüência, também para o atributo de impressão global, 6,27, ou seja, verificando assim, este último, a preferência dos provadores. Cabe ressaltar que estudos específicos precisam ser realizados para verificar a possibilidade de ingestão deste iogurte por indivíduos alérgicos às proteínas do leite de vaca.

$\mathrm{O}$ iogurte de leite de cabra desnatado adicionado de pectina $0,5 \%$, embora tenha apresentado altas notas para os atributos cor, viscosidade (quanto a textura) e a maior nota para atributo de consistência (tanto na aparência quanto na textura) apresentou 
problemas de sabor amargo e presença de grânulos, sendo apontado pelos provadores como o pior tratamento em termo de impressão global e iogurte característico. Portanto, pode-se concluir que embora, este tratamento tenha sido satisfatório para 0 aperfeiçoamento da textura do iogurte de leite de cabra desnatado, foi rejeitado sensorialmente pelos provadores, sendo inviável, na atual avaliação, a sua produção comercial. Estudos posteriores podem ser feitos com intuito de por exemplo, acrescentar-se polpa de frutas, visando mascarar o sabor amargo deste tratamento, ou a utilização de outros recursos tecnológicos para a melhoria do produto final.

Quanto ao iogurte de leite de cabra desnatado adicionado de carragena $0,1 \%$ e pectina $0,1 \%$, este apresentou em relação a aparência uma coloração mais próxima a branca, as menores notas para a consistência tanto para aparência quanto para a textura e para viscosidade, assim como também, em ambas características, para a presença de grânulos, significando para os provadores, ser este tratamento o mais homogêneo quando comparado aos demais. Este tratamento, conforme observado foi o menos consistente e viscoso entre os demais e, portanto não solucionou o problema de textura do iogurte de leite de cabra desnatado natural. Quanto ao sabor amargo, doce, característico e impressão global, não foram detectadas diferenças significativas. $\mathrm{O}$ iogurte de leite de cabra desnatado adicionado de carragena $0,1 \%$ e pectina $0,1 \%$, de acordo com as características levantadas sensorialmente talvez, fosse melhor aproveitado na forma de iogurte batido, porém distante do objetivo esperado neste trabalho. 


\section{CONCLUSÕES}

-O iogurte de leite de cabra desnatado adicionado de leite em pó desnatado de vaca foi o que apresentou, de modo geral, as melhores características de aparência, textura e sabor na Avaliação Sensorial, sendo considerado portanto o mais promissor para o mercado.

-O iogurte de leite de cabra desnatado adicionado de pectina 0,5\%, apresentou excelentes notas para os atributos de consistência e viscosidade, porém apresentou grânulos e sabor amargo, sendo na impressão global, rejeitado pelos provadores.

-O iogurte de leite de cabra desnatado adicionado de carragena $0,1 \%$ e pectina $0,1 \%$, não apresentou os resultados esperados pois embora sendo considerado o tratamento mais homogêneo entre os demais, foi também o menos consistente e viscoso. 
ANEXOS 
Anexo 1. Dados originais da análise do leite de cabra no primeiro bloco.

\begin{tabular}{|c|c|c|c|c|}
\hline $\begin{array}{c}\text { Análise Físico- } \\
\text { Químicas }\end{array}$ & $\begin{array}{c}1^{\mathrm{a}} . \\
\text { Repetição }\end{array}$ & $\begin{array}{c}2^{\mathrm{a}} . \\
\text { Repetição }\end{array}$ & $\begin{array}{c}3^{\mathrm{a}} . \\
\text { Repetição }\end{array}$ & Média \\
\hline $\mathrm{pH}$ & 6,66 & 6,64 & 6,61 & 6,64 \\
\hline $\begin{array}{c}\text { Acidez Titulável } \\
(\%)\end{array}$ & 17,93 & 17,93 & 16,88 & 17,58 \\
\hline Gordura (\%) & 0,1 & 0,1 & 0,1 & 0,1 \\
\hline Densidade & 1,032 & - & - & 1,032 \\
\hline $\begin{array}{c}\text { Extrato Seco Total } \\
(\%)\end{array}$ & 9,19 & 9,18 & 9,21 & 9,19 \\
\hline Proteína Total (\%) & 3,22 & 3,30 & 3,25 & 3,26 \\
\hline Cinzas (\%) & 1,089 & 1,106 & 1,119 & 1,105 \\
\hline
\end{tabular}

Anexo 2. Dados originais da análise do leite de cabra no segundo bloco.

\begin{tabular}{|c|c|c|c|c|}
\hline $\begin{array}{c}\text { Análise Físico- } \\
\text { Químicas }\end{array}$ & $\begin{array}{c}1^{\mathrm{a}} . \\
\text { Repetição }\end{array}$ & $\begin{array}{c}2^{\mathrm{a}} . \\
\text { Repetição }\end{array}$ & $\begin{array}{c}3^{\mathrm{a}} . \\
\text { Repetição }\end{array}$ & Média \\
\hline $\mathrm{pH}$ & 6,62 & 6,63 & 6,63 & 6,63 \\
\hline $\begin{array}{c}\text { Acidez Titulável } \\
\text { (\%) }\end{array}$ & 18,85 & 18,85 & 18,85 & 18,85 \\
\hline Gordura (\%) & 0,1 & 0,1 & 0,1 & 0,1 \\
\hline Densidade & 1,0336 & - & - & 1,0336 \\
\hline $\begin{array}{c}\text { Extrato Seco Total } \\
(\%)\end{array}$ & 9,03 & 9,02 & 9,02 & 9,02 \\
\hline Proteína Total (\%) & 3,46 & 3,39 & 3,38 & 3,41 \\
\hline Cinzas (\%) & 0,926 & - & 0,914 & 0,920 \\
\hline
\end{tabular}


Anexo 3. Dados originais da análise do leite de cabra no terceiro bloco.

\begin{tabular}{|c|c|c|c|c|}
\hline $\begin{array}{c}\text { Análise Físico- } \\
\text { Químicas }\end{array}$ & $\begin{array}{c}1^{\mathrm{a}} . \\
\text { Repetição }\end{array}$ & $\begin{array}{c}2^{\mathrm{a}} . \\
\text { Repetição }\end{array}$ & $\begin{array}{c}3^{\mathrm{a}} . \\
\text { Repetição }\end{array}$ & Média \\
\hline $\mathrm{pH}$ & 6,63 & 6,63 & 6,64 & 6,63 \\
\hline $\begin{array}{c}\text { Acidez Titulável } \\
\left({ }^{\circ} \mathrm{D}\right)\end{array}$ & 18,76 & 18,23 & 19,28 & 18,76 \\
\hline Gordura (\%) & 0,1 & 0,1 & 0,1 & 0,1 \\
\hline Densidade & 1,0343 & - & 9,68 & 1,0343 \\
\hline $\begin{array}{c}\text { Extrato Seco Total } \\
(\%)\end{array}$ & 9,55 & 9,66 & & 9,63 \\
\hline Proteína Total (\%) & - & 3,34 & 3,39 & 3,36 \\
\hline Cinzas (\%) & 1,097 & 0,8025 & 0,7024 & 0,87 \\
\hline
\end{tabular}

Anexo 4. Dados originais da análise do leite de cabra no quarto bloco.

\begin{tabular}{|c|c|c|c|c|}
\hline $\begin{array}{c}\text { Análise Físico- } \\
\text { Químicas }\end{array}$ & $\begin{array}{c}1^{\mathrm{a}} . \\
\text { Repetição }\end{array}$ & $\begin{array}{c}2^{\mathrm{a}} . \\
\text { Repetição }\end{array}$ & $\begin{array}{c}3^{\mathrm{a}} . \\
\text { Repetição }\end{array}$ & Média \\
\hline $\mathrm{pH}$ & 6,67 & 6,67 & 6,67 & 6,67 \\
\hline $\begin{array}{c}\text { Acidez Titulável } \\
\left({ }^{0} \mathrm{D}\right)\end{array}$ & 17,71 & - & 17,71 & 17,71 \\
\hline Gordura (\%) & 0,1 & 0,1 & 0,1 & 0,1 \\
\hline Densidade & 1,0343 & - & - & 1,0343 \\
\hline $\begin{array}{c}\text { Extrato Seco Total } \\
(\%)\end{array}$ & 9,63 & 9,63 & 9,52 & 9,59 \\
\hline Proteína Total (\%) & 3,45 & 3,66 & 3,52 & 3,54 \\
\hline Cinzas (\%) & 0,9414 & 1,1332 & 0,8809 & 0,9800 \\
\hline
\end{tabular}


Anexo 5. Dados originais da análise do leite de cabra no quinto bloco.

\begin{tabular}{|c|c|c|c|c|}
\hline $\begin{array}{c}\text { Análise Físico- } \\
\text { Químicas }\end{array}$ & $\begin{array}{c}1^{\mathrm{a}} . \\
\text { Repetição }\end{array}$ & $\begin{array}{c}2^{\mathrm{a}} . \\
\text { Repetição }\end{array}$ & $\begin{array}{c}3^{\mathrm{a}} . \\
\text { Repetição }\end{array}$ & Média \\
\hline $\mathrm{pH}$ & 6,73 & 6,73 & 6,73 & 6,73 \\
\hline $\begin{array}{c}\text { Acidez Titulável } \\
(\%)\end{array}$ & 17,71 & 18,23 & 17,19 & 17,71 \\
\hline Gordura (\%) & 0,1 & 0,1 & 0,1 & 0,1 \\
\hline Densidade & 1,0337 & - & - & 1,0337 \\
\hline $\begin{array}{c}\text { Extrato Seco Total } \\
(\%)\end{array}$ & 9,87 & 9,81 & 9,78 & 9,82 \\
\hline Proteína Total (\%) & 3,39 & 3,39 & 3,41 & 3,40 \\
\hline Cinzas (\%) & 0,6800 & 0,6100 & 0,7600 & 0,6800 \\
\hline
\end{tabular}

Anexo 6.Análises físico-químicas do iogurte de leite de cabra no primeiro e quinto dia após a fabricação - Data: 06/01/00 (T=1) $1^{0}$. Bloco

\begin{tabular}{|c|c|c|c|c|}
\hline TRATAMENTOS & \multicolumn{3}{|c|}{$\mathrm{pH}$} & MÉDIA \\
\hline Carragena/Pectina & 4,25 & 4,26 & 4,26 & 4,26 \\
\hline Pectina & 4,12 & 4,13 & 4,13 & 4,12 \\
\hline Leite em Pó & 4,31 & 4,31 & 4,31 & 4,31 \\
\hline \multirow[t]{2}{*}{ Controle } & 4,29 & 4,28 & 4,29 & 4,29 \\
\hline & \multicolumn{3}{|c|}{ Acidez Titulável } & \\
\hline Carragena/Pectina & $103,00^{\circ} \mathrm{D}$ & $100,94^{0} \mathrm{D}$ & $100,42^{\circ} \mathrm{D}$ & $101,45^{\circ} \mathrm{D}$ \\
\hline Pectina & $105,00^{\circ} \mathrm{D}$ & $118,00^{\circ} \mathrm{D}$ & $111,00^{\circ} \mathrm{D}$ & $111,33^{\circ} \mathrm{D}$ \\
\hline Leite em Pó & $140,08^{0} \mathrm{D}$ & $134,41^{\circ} \mathrm{D}$ & $141,11^{\circ} \mathrm{D}$ & $138,53^{\circ} \mathrm{D}$ \\
\hline \multirow[t]{2}{*}{ Controle } & $93,73^{\circ} \mathrm{D}$ & $93,73^{0} \mathrm{D}$ & $96,30^{\circ} \mathrm{D}$ & $94,59^{\circ} \mathrm{D}$ \\
\hline & \multicolumn{3}{|c|}{ Proteína Total } & \\
\hline Carragena/Pectina & $3,08 \%$ & $2,98 \%$ & $2,94 \%$ & $3,00 \%$ \\
\hline Pectina & $2,79 \%$ & $2,81 \%$ & - - & $2,80 \%$ \\
\hline Leite em Pó & $5,47 \%$ & $5,46 \%$ & $5,59 \%$ & $5,51 \%$ \\
\hline \multirow[t]{2}{*}{ Controle } & $3,05 \%$ & $3,11 \%$ & $2,94 \%$ & $3,03 \%$ \\
\hline & \multicolumn{3}{|c|}{ Extrato Seco Total } & \\
\hline Carragena/Pectina & $8,12 \%$ & $8,04 \%$ & --.--- & $8,10 \%$ \\
\hline Pectina & $7,01 \%$ & $7,09 \%$ & - - & $7,05 \%$ \\
\hline Leite em Pó & $14,84 \%$ & $15,19 \%$ & 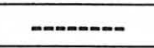 & $15,01 \%$ \\
\hline Controle & $8,06 \%$ & $8,06 \%$ & - -.--- & $8,06 \%$ \\
\hline
\end{tabular}


Anexo 7.Análises físico-químicas do iogurte de leite de cabra no primeiro e quinto dia após a fabricação - Data: $11 / 01 / 00(T=1) 1^{0}$. Bloco

\begin{tabular}{|c|c|c|c|c|}
\hline TRATAMENTOS & \multicolumn{3}{|c|}{ pH } & MÉDIA \\
\hline Carragena/Pectina & 4,28 & 4,28 & 4,29 & 4,28 \\
\hline Pectina & 4,08 & 4,08 & 4,08 & 4,08 \\
\hline Leite em Pó & 4,35 & 4,37 & 4,37 & 4,36 \\
\hline \multirow[t]{2}{*}{ Controle } & 4,32 & 4,32 & 4,32 & 4,32 \\
\hline & \multicolumn{3}{|c|}{ Acidez Titulável } & \\
\hline Carragena/Pectina & $93,73^{\circ} \mathrm{D}$ & $94,76^{\circ} \mathrm{D}$ & $96,30^{\circ} \mathrm{D}$ & $94,93^{\circ} \mathrm{D}$ \\
\hline Pectina & $116,39^{\circ} \mathrm{D}$ & $107,12^{\circ} \mathrm{D}$ & $121,02^{\circ} \mathrm{D}$ & $114,84^{\circ} \mathrm{D}$ \\
\hline Leite em Pó & $115,87^{\circ} \mathrm{D}$ & $113,81^{\circ} \mathrm{D}$ & $114,84^{\circ} \mathrm{D}$ & $114,84^{\circ} \mathrm{D}$ \\
\hline \multirow[t]{2}{*}{ Controle } & $98,36^{\circ} \mathrm{D}$ & $95,79^{0} \mathrm{D}$ & $86,52^{0} \mathrm{D}$ & $93,56^{0} \mathrm{D}$ \\
\hline & \multicolumn{3}{|c|}{ Proteína Total } & \\
\hline Carragena/Pectina & $3,12 \%$ & $3,19 \%$ & $3,27 \%$ & $3,19 \%$ \\
\hline Pectina & $2,94 \%$ & $3,08 \%$ & $2,91 \%$ & $2,98 \%$ \\
\hline Leite em Pó & $5,49 \%$ & $5,02 \%$ & $5,33 \%$ & $5,28 \%$ \\
\hline \multirow[t]{2}{*}{ Controle } & $2,84 \%$ & $2,57 \%$ & $2,42 \%$ & $2,61 \%$ \\
\hline & \multicolumn{3}{|c|}{ Extrato Seco Total } & \\
\hline Carragena/Pectina & $6,70 \%$ & $7,11 \%$ & ---.-- & $6,90 \%$ \\
\hline Pectina & $7,60 \%$ & $7,47 \%$ & - - - - & $7,53 \%$ \\
\hline Leite em Pó & $14,25 \%$ & $13,90 \%$ & - -.--- & $14,07 \%$ \\
\hline Controle & $6,10 \%$ & $6,22 \%$ & $\begin{array}{ll}-\cdots-- \\
-\cdots-\end{array}$ & $6,16 \%$ \\
\hline
\end{tabular}

Anexo 8. Análises físico-químicas do iogurte de leite de cabra no primeiro e quinto dia após a $\begin{array}{lll}\text { fabricação - Data: } 13 / 01 / 00 & (T=1) \quad 2^{0} \text {. Bloco }\end{array}$

\begin{tabular}{|c|c|c|c|c|}
\hline TRATAMENTOS & \multicolumn{3}{|c|}{$\mathrm{pH}$} & MÉDIA \\
\hline Carragena/Pectina & 4,10 & 4,10 & 4,10 & 4,10 \\
\hline Pectina & 4,29 & 4,29 & 4,30 & 4,29 \\
\hline Leite em Pó & 4,30 & 4,31 & 4,32 & 4,31 \\
\hline \multirow[t]{2}{*}{ Controle } & 4,19 & 4,18 & 4,19 & 4,19 \\
\hline & \multicolumn{3}{|c|}{ Acidez Titulável } & \\
\hline Carragena/Pectina & $125,00^{\circ} \mathrm{D}$ & $110,00^{\circ} \mathrm{D}$ & $113,67^{0} \mathrm{D}$ & $113,67^{0} \mathrm{D}$ \\
\hline Pectina & $109,00^{\circ} \mathrm{D}$ & $98,00^{\circ} \mathrm{D}$ & $94,00^{\circ} \mathrm{D}$ & $100,33^{0} \mathrm{D}$ \\
\hline Leite em Pó & $136,50^{\circ} \mathrm{D}$ & $115,00^{\circ} \mathrm{D}$ & $126,00^{\circ} \mathrm{D}$ & $125,83^{\circ} \mathrm{D}$ \\
\hline \multirow[t]{2}{*}{ Controle } & $108,00^{\circ} \mathrm{D}$ & $110,00^{\circ} \mathrm{D}$ & $106,50^{\circ} \mathrm{D}$ & $108,17^{0} \mathrm{D}$ \\
\hline & \multicolumn{3}{|c|}{ Proteína Total } & \\
\hline Carragena/Pectina & $2,97 \%$ & $2,83 \%$ & $2,43 \%$ & $2,74 \%$ \\
\hline Pectina & $3,02 \%$ & $3,13 \%$ & $3,01 \%$ & $3,05 \%$ \\
\hline Leite em Pó & $5,05 \%$ & $5,19 \%$ & $5,31 \%$ & $5,18 \%$ \\
\hline \multirow[t]{2}{*}{ Controle } & $2,86 \%$ & $2,89 \%$ & $2,97 \%$ & $2,91 \%$ \\
\hline & \multicolumn{3}{|c|}{ Extrato Seco Total } & \\
\hline Carragena/Pectina & $9,29 \%$ & $9,27 \%$ & -...... & $9,28 \%$ \\
\hline Pectina & $8,05 \%$ & $8,03 \%$ & ------- & $8,04 \%$ \\
\hline Leite em Pó & $13,39 \%$ & $13,63 \%$ & -....... & $13,51 \%$ \\
\hline Controle & $8,82 \%$ & $8,94 \%$ & - -.-.-.- & $8,88 \%$ \\
\hline
\end{tabular}


Anexo 9.Análises físico-químicas do iogurte de leite de cabra no primeiro e quinto dia após a fabricação - Data: $17 / 01 / 00 \quad(T=5) \quad 2^{0}$. Bloco

\begin{tabular}{|c|c|c|c|c|}
\hline TRATAMENTOS & \multicolumn{3}{|c|}{$\mathrm{pH}$} & MÉDIA \\
\hline Carragena/Pectina & 4,08 & 4,08 & 4,08 & 4,08 \\
\hline Pectina & 4,28 & 4,28 & 4,28 & 4,28 \\
\hline Leite em Pó & 4,31 & 4,31 & 4,31 & 4,31 \\
\hline \multirow[t]{2}{*}{ Controle } & 4,17 & 4,17 & 4,17 & 4,17 \\
\hline & \multicolumn{3}{|c|}{ Acidez Titulável } & \\
\hline Carragena/Pectina & $114,00^{\circ} \mathrm{D}$ & $111,00^{\circ} \mathrm{D}$ & $115,00^{\circ} \mathrm{D}$ & $113,33^{\circ} \mathrm{D}$ \\
\hline Pectina & $90,00^{\circ} \mathrm{D}$ & $91,00^{\circ} \mathrm{D}$ & $91,00^{\circ} \mathrm{D}$ & $90,67^{\circ} \mathrm{D}$ \\
\hline Leite em Pó & $124,00^{\circ} \mathrm{D}$ & $127,15^{\circ} \mathrm{D}$ & $137,00^{\circ} \mathrm{D}$ & $129,50^{\circ} \mathrm{D}$ \\
\hline \multirow[t]{2}{*}{ Controle } & $118,00^{\circ} \mathrm{D}$ & $100,00^{\circ} \mathrm{D}$ & $98,00^{\circ} \mathrm{D}$ & $105,33^{\circ} \mathrm{D}$ \\
\hline & \multicolumn{3}{|c|}{ Proteína Total } & \\
\hline Carragena/Pectina & $3,50 \%$ & $3,56 \%$ & $3,45 \%$ & $3,50 \%$ \\
\hline Pectina & $3,47 \%$ & $3,36 \%$ & $3,26 \%$ & $3,36 \%$ \\
\hline Leite em Pó & $5,45 \%$ & $5,36 \%$ & $5,27 \%$ & $5,36 \%$ \\
\hline \multirow[t]{2}{*}{ Controle } & $3,24 \%$ & $3,29 \%$ & $3,40 \%$ & $3,31 \%$ \\
\hline & \multicolumn{3}{|c|}{ Extrato Seco Total } & \\
\hline Carragena/Pectina & $5,98 \%$ & $6,07 \%$ & --.---- & $6,02 \%$ \\
\hline Pectina & $7,62 \%$ & $7,63 \%$ & -------- & $7,62 \%$ \\
\hline Leite em Pó & $14,52 \%$ & $14,81 \%$ & - & $14,66 \%$ \\
\hline Controle & $6,42 \%$ & $7,01 \%$ & 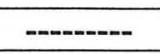 & $6,96 \%$ \\
\hline
\end{tabular}

Anexo 10.Análises físico-químicas do iogurte de leite de cabra no primeiro e quinto dia após a fabricação - Data: 20/01/00 (T=1) $\quad 3^{0}$. Bloco

\begin{tabular}{|c|c|c|c|c|}
\hline TRATAMENTOS & \multicolumn{3}{|c|}{ pH } & MÉDIA \\
\hline Carragena/Pectina & 4,17 & 4,18 & 4,18 & 4,18 \\
\hline Pectina & 4,13 & 4,15 & 4,16 & 4,15 \\
\hline Leite em Pó & 4,21 & 4,22 & 4,24 & 4,22 \\
\hline Controle & 4,17 & 4,17 & 4,17 & 4,17 \\
\hline \multicolumn{4}{|c|}{ Acidez Titulável } \\
\hline Carragena/Pectina & $98,00^{\circ} \mathrm{D}$ & $95,00^{\circ} \mathrm{D}$ & $113,00^{\circ} \mathrm{D}$ & $102,00{ }^{\circ} \mathrm{D}$ \\
\hline Pectina & $98,00^{\circ} \mathrm{D}$ & $100,00^{\circ} \mathrm{D}$ & $90,00^{\circ} \mathrm{D}$ & $96,00 \mathrm{D}$ \\
\hline Leite em Pó & $145,00^{\circ} \mathrm{D}$ & $150,00^{\circ} \mathrm{D}$ & $154,00{ }^{\circ} \mathrm{D}$ & $149,67^{\circ} \mathrm{D}$ \\
\hline Controle & $109,00^{\circ} \mathrm{D}$ & $126,00^{\circ} \mathrm{D}$ & $118,00^{\circ} \mathrm{D}$ & $117,67^{\circ} \mathrm{D}$ \\
\hline \multicolumn{4}{|c|}{ Proteína Total } \\
\hline Carragena/Pectina & $2,59 \%$ & $2,64 \%$ & $2,81 \%$ & $2,68 \%$ \\
\hline Pectina & $2,30 \%$ & $2,41 \%$ & $2,42 \%$ & $2,38 \%$ \\
\hline Leite em Pó & $4,90 \%$ & $4,81 \%$ & $5,05 \%$ & $4,92 \%$ \\
\hline Controle & $2,54 \%$ & $2,77 \%$ & $2,51 \%$ & $2,61 \%$ \\
\hline Carragena/Pectina & $9,59 \%$ & $9,48 \%$ & $-\cdots$ & $9,53 \%$ \\
\hline Pectina & $8,52 \%$ & $8,38 \%$ & $-\cdots$ & $8,45 \%$ \\
\hline Leite em Pó & $12,88 \%$ & $12,87 \%$ & $-\cdots$ & $12,87 \%$ \\
\hline Controle & $10,93 \%$ & $11,00 \%$ & $-\cdots$ & $10,96 \%$ \\
\hline
\end{tabular}


Anexo 11.Análises físico-químicas do iogurte de leite de cabra no primeiro e quinto dia após a fabricação - Data: $24 / 01 / 00 \quad(T=5) \quad 3^{0}$. Bloco

\begin{tabular}{|c|c|c|c|c|}
\hline TRATAMENTOS & \multicolumn{3}{|c|}{$\mathrm{pH}$} & MÉDIA \\
\hline Carragena/Pectina & 4,12 & 4,12 & 4,12 & 4,12 \\
\hline Pectina & 4,11 & 4,11 & 4,11 & 4,11 \\
\hline Leite em Pó & 4,21 & 4,21 & 4,21 & 4,21 \\
\hline Controle & 4,14 & 4,14 & 4,14 & 4,14 \\
\hline & \multicolumn{3}{|c|}{ Acidez Titulável } & \\
\hline Carragena/Pectina & $119,00^{\circ} \mathrm{D}$ & $114,00^{\circ} \mathrm{D}$ & $122,00^{\circ} \mathrm{D}$ & $118,50^{\circ} \mathrm{D}$ \\
\hline Pectina & $130,00^{\circ} \mathrm{D}$ & $135,00^{\circ} \mathrm{D}$ & $127,50^{\circ} \mathrm{D}$ & $130,83^{\circ} \mathrm{D}$ \\
\hline Leite em Pó & $156,00^{\circ} \mathrm{D}$ & $151,50^{\circ} \mathrm{D}$ & $162,50^{\circ} \mathrm{D}$ & $156,67^{0} \mathrm{D}$ \\
\hline \multirow[t]{2}{*}{ Controle } & $120,00^{\circ} \mathrm{D}$ & $120,00^{\circ} \mathrm{D}$ & $126,00^{\circ} \mathrm{D}$ & $122,00^{\circ} \mathrm{D}$ \\
\hline & \multicolumn{3}{|c|}{ Proteína Total } & \\
\hline Carragena/Pectina & $3,21 \%$ & $3,32 \%$ & $3,34 \%$ & $3,29 \%$ \\
\hline Pectina & $3,54 \%$ & $3,36 \%$ & $3,47 \%$ & $3,46 \%$ \\
\hline Leite em Pó & $5,53 \%$ & $5,66 \%$ & $5,36 \%$ & $5,52 \%$ \\
\hline \multirow[t]{2}{*}{ Controle } & $3,41 \%$ & $3,33 \%$ & $3,38 \%$ & $3,37 \%$ \\
\hline & \multicolumn{3}{|c|}{ Extrato Seco Total } & \\
\hline Carragena/Pectina & $7,85 \%$ & $7,00 \%$ & -.---- & $7,82 \%$ \\
\hline Pectina & $7,20 \%$ & $7,37 \%$ & --o--- & $7,28 \%$ \\
\hline Leite em Pó & $13,30 \%$ & $13,31 \%$ & - -..---- & $13,30 \%$ \\
\hline Controle & $7,31 \%$ & $7,31 \%$ & - - & $7,31 \%$ \\
\hline
\end{tabular}

Anexo 12.Análises físico-químicas do iogurte de leite de cabra no primeiro e quinto dia após a fabricação - Data: 27/01/00 (T=1) $\quad 4^{0}$. Bloco

\begin{tabular}{|c|c|c|c|c|}
\hline TRATAMENTOS & \multicolumn{3}{|c|}{ pH } & MÉDIA \\
\hline Carragena/Pectina & 4,19 & 4,19 & 4,19 & 4,19 \\
\hline Pectina & 4,39 & 4,37 & 4,39 & 4,38 \\
\hline Leite em Pó & 4,38 & 4,38 & 4,38 & 4,38 \\
\hline Controle & 4,21 & 4,23 & 4,23 & 4,22 \\
\hline \multicolumn{4}{|c|}{ Acidez Titulável } \\
\hline Carragena/Pectina & $165,00^{\circ} \mathrm{D}$ & $130,00^{\circ} \mathrm{D}$ & $135,00^{\circ} \mathrm{D}$ & $143,33^{\circ} \mathrm{D}$ \\
\hline Pectina & $90,00^{\circ} \mathrm{D}$ & $97,00^{\circ} \mathrm{D}$ & $88,00^{\circ} \mathrm{D}$ & $91,67^{\circ} \mathrm{D}$ \\
\hline Leite em Pó & $132,00^{\circ} \mathrm{D}$ & $136,00^{\circ} \mathrm{D}$ & $136,00^{\circ} \mathrm{D}$ & $134,67^{\circ} \mathrm{D}$ \\
\hline Controle & $113,00^{\circ} \mathrm{D}$ & $109,00^{\circ} \mathrm{D}$ & $123,00^{\circ} \mathrm{D}$ & $115,00^{\circ} \mathrm{D}$ \\
\hline \multicolumn{4}{|c|}{ Proteína Total } \\
\hline Carragena/Pectina & $2,83 \%$ & $2,84 \%$ & $2,60 \%$ & $2,76 \%$ \\
\hline Pectina & $3,28 \%$ & $3,12 \%$ & $3,17 \%$ & $3,19 \%$ \\
\hline Leite em Pó & $4,63 \%$ & $4,81 \%$ & $-\cdots$ & $4,72 \%$ \\
\hline Controle & $2,82 \%$ & $2,89 \%$ & $2,60 \%$ & $2,77 \%$ \\
\hline Carragena/Pectina & $9,21 \%$ & $9,26 \%$ & $\cdots$ & $9,23 \%$ \\
\hline Pectina & $8,54 \%$ & $8,65 \%$ & $-\cdots$ & $8,59 \%$ \\
\hline Leite em Pó & $13,51 \%$ & $13,91 \%$ & $\cdots$ & $13,71 \%$ \\
\hline Controle & $7,66 \%$ & $7,72 \%$ & $\cdots$ & $7,71 \%$ \\
\hline
\end{tabular}


Anexo 13.Análises físico-químicas do iogurte de leite de cabra no primeiro e quinto dia após a fabricação - Data: $31 / 01 / 00 \quad(T=5) \quad 4^{\circ}$. Bloco

\begin{tabular}{|c|c|c|c|c|}
\hline TRATAMENTOS & \multicolumn{3}{|c|}{ pH } & MEDIA \\
\hline Carragena/Pectina & 4,15 & 4,15 & 4,15 & 4,15 \\
\hline Pectina & 4,29 & 4,29 & 4,29 & 4,29 \\
\hline Leite em Pó & 4,32 & 4,33 & 4,33 & 4,33 \\
\hline Controle & 4,18 & 4,18 & 4,18 & 4,18 \\
\hline \multicolumn{4}{|c|}{ Acidez Titulável } \\
\hline Carragena/Pectina & $100,00^{\circ} \mathrm{D}$ & $94,00^{\circ} \mathrm{D}$ & $95,00^{\circ} \mathrm{D}$ & $96,33^{\circ} \mathrm{D}$ \\
\hline Pectina & $89,00^{\circ} \mathrm{D}$ & $87,00^{\circ} \mathrm{D}$ & $88,67^{\circ} \mathrm{D}$ & $88,67^{\circ} \mathrm{D}$ \\
\hline Leite em Pó & $137,00^{\circ} \mathrm{D}$ & $119,00^{\circ} \mathrm{D}$ & $147,00^{\circ} \mathrm{D}$ & $134,33^{\circ} \mathrm{D}$ \\
\hline Controle & $105,00^{\circ} \mathrm{D}$ & $96,00^{\circ} \mathrm{D}$ & $93,00^{\circ} \mathrm{D}$ & $98,00^{\circ} \mathrm{D}$ \\
\hline \multicolumn{4}{|c|}{ Proteína Total } \\
\hline Carragena/Pectina & $2,49 \%$ & $2,57 \%$ & $2,65 \%$ & $2,57 \%$ \\
\hline Pectina & $2,92 \%$ & $3,19 \%$ & $3,38 \%$ & $3,16 \%$ \\
\hline Leite em Pó & $4,98 \%$ & $5,05 \%$ & $5,15 \%$ & $5,05 \%$ \\
\hline Controle & $2,20 \%$ & $2,27 \%$ & $2,35 \%$ & $2,27 \%$ \\
\hline Carragena/Pectina & $7,80 \%$ & $7,87 \%$ & $-\cdots$ & $7,83 \%$ \\
\hline Pectina & $7,82 \%$ & $8,50 \%$ & $-\cdots-\cdots$ & $8,16 \%$ \\
\hline Leite em Pó & $14,38 \%$ & $14,42 \%$ & $\cdots$ & $14,40 \%$ \\
\hline Controle & $7,56 \%$ & $7,66 \%$ & $-\cdots---$ & $7,61 \%$ \\
\hline
\end{tabular}

Anexo 14.Análises físico-químicas do iogurte de leite de cabra no primeiro e quinto dia após a fabricação - Data: $03 / 02 / 00 \quad(\mathrm{~T}=1) \quad 5^{0}$. Bloco

\begin{tabular}{|c|c|c|c|c|}
\hline TRATAMENTOS & \multicolumn{3}{|c|}{ pH } & MÉDIA \\
\hline Carragena/Pectina & 4,31 & 4,31 & 4,31 & 4,31 \\
\hline Pectina & 4,26 & 4,26 & 4,26 & 4,26 \\
\hline Leite em Pó & 4,37 & 4,37 & 4,37 & 4,37 \\
\hline Controle & 4,18 & 4,18 & 4,18 & 4,18 \\
\hline \multicolumn{5}{|c|}{ Acidez Titulável } \\
\hline Carragena/Pectina & $114,00^{\circ} \mathrm{D}$ & $111,00^{\circ} \mathrm{D}$ & $106,50^{\circ} \mathrm{D}$ & $110,50^{\circ} \mathrm{D}$ \\
\hline Pectina & $107,50^{\circ} \mathrm{D}$ & $118,00^{\circ} \mathrm{D}$ & $121,00^{\circ} \mathrm{D}$ & $115,50^{\circ} \mathrm{D}$ \\
\hline Leite em Pó & $136,00^{\circ} \mathrm{D}$ & $132,00^{\circ} \mathrm{D}$ & $112,00^{\circ} \mathrm{D}$ & $126,67^{\circ} \mathrm{D}$ \\
\hline Controle & $104,00^{\circ} \mathrm{D}$ & $113,00^{\circ} \mathrm{D}$ & $129,00^{\circ} \mathrm{D}$ & $115,33^{\circ} \mathrm{D}$ \\
\hline \multicolumn{4}{|c|}{ Proteína Total } \\
\hline Carragena/Pectina & $3,23 \%$ & $3,33 \%$ & $3,34 \%$ & $3,30 \%$ \\
\hline Pectina & $3,05 \%$ & $3,08 \%$ & $3,03 \%$ & $3,05 \%$ \\
\hline Leite em Pó & $5,40 \%$ & $5,57 \%$ & $5,99 \%$ & $5,65 \%$ \\
\hline Controle & $2,59 \%$ & $2,66 \%$ & $2,67 \%$ & $2,64 \%$ \\
\hline Carragena/Pectina & $6,97 \%$ & $6,31 \%$ & $-\cdots-\cdots$ & $6,43 \%$ \\
\hline Pectina & $6,88 \%$ & $6,97 \%$ & $-\cdots-\cdots$ & $6,92 \%$ \\
\hline Leite em Pó & $15,71 \%$ & $15,04 \%$ & $-\cdots-\cdots$ & $15,37 \%$ \\
\hline Controle & $7,48 \%$ & $7,50 \%$ & $-\cdots-\cdots$ & $7,49 \%$ \\
\hline
\end{tabular}


Anexo 15.Análises físico-químicas do iogurte de leite de cabra no primeiro e quinto dia após a

\begin{tabular}{|c|c|c|c|c|}
\hline TRATAMENTOS & \multicolumn{3}{|c|}{ pH } & MÉDIA \\
\hline Carragena/Pectina & 4,21 & 4,22 & 4,22 & 4,22 \\
\hline Pectina & 4,20 & 4,20 & 4,20 & 4,20 \\
\hline Leite em Pó & 4,32 & 4,33 & 4,33 & 4,33 \\
\hline \multirow[t]{2}{*}{ Controle } & 4,16 & 4,16 & 4,16 & 4,16 \\
\hline & \multicolumn{3}{|c|}{ Acidez Titulável } & \\
\hline Carragena/Pectina & $96,00^{\circ} \mathrm{D}$ & $113,00^{\circ} \mathrm{D}$ & $106,00^{\circ} \mathrm{D}$ & $105,00^{\circ} \mathrm{D}$ \\
\hline Pectina & $126,00^{\circ} \mathrm{D}$ & $119,00^{\circ} \mathrm{D}$ & $122,00^{\circ} \mathrm{D}$ & $122,33^{\circ} \mathrm{D}$ \\
\hline Leite em Pó & $158,00^{\circ} \mathrm{D}$ & $142,00^{\circ} \mathrm{D}$ & $134,00^{\circ} \mathrm{D}$ & $144,67^{0} \mathrm{D}$ \\
\hline \multirow[t]{2}{*}{ Controle } & $109,00^{\circ} \mathrm{D}$ & $100,00^{\circ} \mathrm{D}$ & $100,00^{\circ} \mathrm{D}$ & $103,00^{\circ} \mathrm{D}$ \\
\hline & \multicolumn{3}{|c|}{ Proteína Total } & \\
\hline Carragena/Pectina & $3,23 \%$ & $3,19 \%$ & $3,15 \%$ & $3,19 \%$ \\
\hline Pectina & $3,51 \%$ & $3,50 \%$ & $3,70 \%$ & $3,57 \%$ \\
\hline Leite em Pó & $5,78 \%$ & $5,17 \%$ & $5,19 \%$ & $5,38 \%$ \\
\hline \multirow[t]{2}{*}{ Controle } & $2,68 \%$ & $3,01 \%$ & $3,16 \%$ & $2,95 \%$ \\
\hline & \multicolumn{3}{|c|}{ Extrato Seco Total } & \\
\hline Carragena/Pectina & $8,35 \%$ & $8,50 \%$ & -.---.-- & $8,42 \%$ \\
\hline Pectina & $9,31 \%$ & $9,28 \%$ & |------ & $9,29 \%$ \\
\hline Leite em Pó & $14,55 \%$ & $14,59 \%$ & 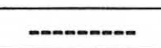 & $14,57 \%$ \\
\hline Controle & $8,08 \%$ & $8,31 \%$ & ------- & $8,19 \%$ \\
\hline
\end{tabular}

Anexo 16. Dados originais relativo aos atributos de aparência cor, brilho, consistência, viscosidade, presença de grânulos, obtido pela "ADQ" da Análise Sensorial do iogurte de leite de cabra após o quinto dia após o processamento.

Obs: Tratamento $1=$ carragena/pectina $0,1 \%$; Tratamento $2=$ pectina $0,5 \%$; Tratamento 3=Leite em pó desnatado; Tratamento 4=testemunha.

$\begin{array}{rrr}\text { Tratamento } & \text { Provador } & \text { Repetições } \\ 1 & 1 & 1 \\ 1 & 1 & 2 \\ 1 & 1 & 3 \\ 1 & 1 & 4 \\ 1 & 2 & 1 \\ 1 & 2 & 2 \\ 1 & 2 & 3 \\ 1 & 2 & 4 \\ 1 & 3 & 1 \\ 1 & 3 & 2 \\ 1 & 3 & 3 \\ 1 & 3 & 4 \\ 1 & 4 & 1 \\ 1 & 4 & 2 \\ 1 & 4 & 3 \\ 1 & 4 & 4 \\ 1 & 5 & 1 \\ 1 & 5 & 2 \\ 1 & 5 & 3 \\ 1 & 5 & 4\end{array}$

$\begin{array}{rr}\text { Cor } & \text { Brilho } \\ 2,2 & 5,7 \\ 2,4 & 8 \\ 1,9 & 7,5 \\ 1,8 & 7,5 \\ 4,3 & 6,7 \\ 1,7 & 6 \\ 4,8 & 3,9 \\ 2,5 & 8,2 \\ 1,2 & 1,2 \\ 1,2 & 7,6 \\ 1,4 & 6,8 \\ 1,4 & 6,5 \\ 1,9 & 3,3 \\ 1,5 & 3 \\ 1,6 & 1,8 \\ 3 & 3,3 \\ 1,2 & 5,5 \\ 1,3 & 4,2 \\ 1,1 & 8,9 \\ 1,7 & 8,2\end{array}$

Consistência
2,5
1,2
1,7
3,6
2,6
1,8
1,5
2,4
5,2
6,5
7,8
6,6
2
2,1
2,9
2
2
2,2
4,9
2,3

$\begin{array}{rr}\text { Viscosidade } & \text { Pres. de Grânulos } \\ 8 & 2,7 \\ 1,7 & 1,2 \\ 5 & 6,1 \\ 5,2 & 3,8 \\ 5,9 & 3,5 \\ 7,3 & 8 \\ 3,1 & 2,4 \\ 0,3 & 0,2 \\ 8,6 & 8,3 \\ 4,1 & 1,3 \\ 8,2 & 1,6 \\ 7,3 & 1,4 \\ 1,9 & 5 \\ 1,7 & 2,2 \\ 1,8 & 5 \\ 1,9 & 2,1 \\ 8,5 & 3,1 \\ 1,3 & 8,2 \\ 7 & 4,9 \\ 4,4 & 8,3\end{array}$




\begin{tabular}{|c|c|c|c|c|c|c|c|}
\hline 1 & 6 & 1 & 1,9 & 5,6 & 2,6 & 1,9 & 3,8 \\
\hline 1 & 6 & 2 & 2,7 & 6,3 & 3,6 & 3 & 2 \\
\hline 1 & 6 & 3 & 3,2 & 4,9 & 3,7 & 3 & 1,9 \\
\hline 1 & 6 & 4 & 4 & 6,1 & 2,9 & 2,9 & 1,9 \\
\hline 1 & 7 & 1 & 2,7 & 6,4 & 4,6 & 4,8 & 4,1 \\
\hline 1 & 7 & 2 & 2,2 & 7,3 & 2,8 & 3,7 & \\
\hline 1 & 7 & 3 & 2,9 & 6 & 4,5 & 6,1 & 7 \\
\hline 1 & 7 & 4 & 4,6 & 6 & 3,8 & 3,1 & 4,9 \\
\hline 1 & 8 & 1 & 2,8 & 8,2 & 3,3 & 3,3 & 2,6 \\
\hline 1 & 8 & 2 & 3,1 & 8,1 & 2,1 & 2,3 & 2,2 \\
\hline 1 & 8 & 3 & 1,8 & 8,3 & 2,2 & 1,5 & 1,6 \\
\hline 1 & 8 & 4 & 1,8 & 8,9 & 1,8 & 1,9 & 1,3 \\
\hline 1 & 9 & 1 & 2 & 3 & 3,1 & 1,3 & 7,2 \\
\hline 1 & 9 & 2 & $1, \overline{5}$ & 8,5 & 1,9 & 8,6 & 1,4 \\
\hline 1 & 9 & 3 & 1,3 & 8,5 & 6,6 & 8,6 & 1,5 \\
\hline 1 & 9 & 4 & 1,8 & 8,2 & 1,4 & 8,1 & 5,9 \\
\hline 1 & 10 & 1 & 5,7 & 6,9 & 8,1 & 8,7 & 4,6 \\
\hline 1 & 10 & 2 & 1,6 & 8,1 & 1,7 & 1,9 & 4 \\
\hline 1 & 10 & 3 & 1 & 8,9 & 1,9 & 1,3 & 1 \\
\hline 1 & 10 & 4 & 1,3 & 8,7 & 1,8 & 1,3 & 7 \\
\hline 2 & 1 & 1 & 5,2 & 5,4 & 7,8 & 2,5 & 7,7 \\
\hline 2 & 1 & 2 & 3,7 & 6,9 & 7,1 & 4 & 2,7 \\
\hline 2 & 1 & 3 & 2,9 & 6,7 & 8,2 & 1,7 & 2,2 \\
\hline 2 & 1 & 4 & 3,1 & 6,9 & 8,2 & 3 & 5,3 \\
\hline 2 & 2 & 1 & 2,4 & 5,7 & 8,4 & 1,3 & \\
\hline 2 & 2 & 2 & 3,7 & 8,3 & 8,3 & 1,7 & 2,8 \\
\hline 2 & 2 & 3 & 3,1 & 5 & 9,8 & 4,3 & 3,1 \\
\hline 2 & 2 & 4 & 4,7 & 2 & 9,4 & 7,6 & \\
\hline 2 & 3 & 1 & 1,2 & 1,2 & 5,9 & 1,5 & 8,9 \\
\hline 2 & 3 & 2 & 1,2 & 7,5 & 8,8 & 7,9 & 1,3 \\
\hline 2 & 3 & 3 & 1,7 & 8,7 & 8,7 & 8,2 & 1,2 \\
\hline 2 & 3 & 4 & 1,4 & 6,8 & 8,8 & 8,7 & 1,4 \\
\hline 2 & 4 & 1 & 2,6 & 5,1 & 8,3 & 7,3 & 8,2 \\
\hline 2 & 4 & 2 & 3 & 2,1 & 3,9 & 3,9 & 7 \\
\hline 2 & 4 & 3 & 3,3 & 3,5 & 3,7 & 4 & 6 \\
\hline 2 & 4 & 4 & 3,7 & 2 & 4 & 3,2 & 5 \\
\hline 2 & 5 & 1 & 1,2 & $8, \overline{7}$ & 8,7 & 1,1 & 8,1 \\
\hline 2 & 5 & 2 & 1,9 & 8,8 & 8,4 & 8,6 & 1,5 \\
\hline 2 & 5 & 3 & 1,1 & 8,9 & 8,6 & 7,9 & 8,6 \\
\hline 2 & 5 & 4 & 1,6 & 8,2 & 2,3 & 5,9 & 8,5 \\
\hline 2 & 6 & 1 & 3,8 & 3,7 & 5,6 & 7,2 & 6,6 \\
\hline 2 & 6 & 2 & 3,7 & 5,2 & 4,7 & 5 & 4,9 \\
\hline 2 & 6 & 3 & 5,9 & 5,8 & 4,9 & 6,1 & 6,9 \\
\hline 2 & 6 & 4 & 5 & 2,8 & 6,9 & 7 & 8 \\
\hline 2 & 7 & 1 & 3 & 6,3 & 8,1 & 6,2 & 6,7 \\
\hline 2 & 7 & 2 & 2,2 & 7,2 & 5,6 & 5,6 & 4,7 \\
\hline 2 & 7 & 3 & 4,6 & 7,2 & 7,2 & 7,8 & \\
\hline 2 & 7 & 4 & 6,2 & 4,8 & 8,1 & 7,8 & 7,4 \\
\hline 2 & 8 & 1 & 4,8 & 8,2 & 8,6 & 8,9 & 6 \\
\hline 2 & 8 & 2 & 1,9 & 8,1 & 8,5 & 8,4 & 8,7 \\
\hline 2 & 8 & 3 & 1,7 & 7,3 & 8,5 & 8,8 & \\
\hline 2 & 8 & 4 & 4,7 & 8,8 & 8,2 & 3,5 & 8,8 \\
\hline 2 & 9 & 1 & 2,5 & 3,5 & 8,8 & 1,9 & 3,3 \\
\hline 2 & 9 & 2 & 1,5 & 3,6 & 8,5 & 1,4 & 8,3 \\
\hline 2 & 9 & 3 & 2,2 & 1,9 & 8,8 & 1,8 & 1,4 \\
\hline 2 & 9 & 4 & 2,4 & 8,2 & 8,6 & 1,3 & 4 \\
\hline 2 & 10 & 1 & 6,2 & 3,5 & 9,2 & 1 & 9,3 \\
\hline 2 & 10 & 2 & 1,4 & 8,1 & 9 & 9 & 1,8 \\
\hline 2 & 10 & 3 & 1,6 & 8,3 & 8,9 & 9 & 2 \\
\hline 2 & 10 & 4 & 1,3 & 8,1 & 8,8 & 7,8 & 1,2 \\
\hline 3 & 1 & 1 & 4,9 & 5,3 & 6,2 & 5,3 & 6,6 \\
\hline 3 & 1 & 2 & 3,8 & 7,5 & 7,8 & 4,8 & 3,3 \\
\hline 3 & 1 & 3 & 2,8 & 6,2 & 7,5 & 1,9 & 2 \\
\hline 3 & 1 & 4 & 3,1 & 7 & 7,1 & 7,5 & 5,1 \\
\hline 3 & 2 & 1 & 2,7 & 7,4 & 7,2 & 1,5 & \\
\hline 3 & 2 & 2 & 3,1 & 8,7 & 8,9 & 1,7 & 2,8 \\
\hline 3 & 2 & 3 & 5,4 & 7,3 & 8,8 & 4,3 & \\
\hline
\end{tabular}




\begin{tabular}{|c|c|c|c|c|c|c|c|}
\hline 3 & 2 & 4 & 4,2 & 6,9 & 9,1 & 8,2 & 3,4 \\
\hline 3 & 3 & 1 & 1,2 & 1,2 & 6,1 & 1,5 & 8,8 \\
\hline 3 & 3 & 2 & 1,2 & 7,2 & 8,8 & 7,9 & 1,3 \\
\hline 3 & 3 & 3 & 1,7 & 8,8 & 8,7 & 8,8 & 1,6 \\
\hline 3 & 3 & 4 & 1,4 & 6,8 & 8,5 & 8,7 & 1,6 \\
\hline 3 & 4 & 1 & 3,5 & 7,1 & 8,3 & 7,3 & 8,2 \\
\hline 3 & 4 & 2 & 3,8 & 3,9 & 3,9 & 5,1 & 8,2 \\
\hline 3 & 4 & 3 & 4,1 & 3,4 & 4,6 & 5 & $\begin{array}{l}8,2\end{array}$ \\
\hline 3 & 4 & 4 & 5 & 5,1 & 5,1 & 5 & 6 \\
\hline 3 & 5 & 1 & 1,1 & 8,9 & 8,5 & 1,1 & 8,2 \\
\hline 3 & 5 & 2 & 1,9 & 8,9 & 8,7 & 8,7 & 1,2 \\
\hline 3 & 5 & 3 & 1,1 & 8,9 & 8,4 & 7,9 & 8,4 \\
\hline 3 & 5 & 4 & 1,6 & 8,8 & 8,3 & 7 & \\
\hline 3 & 6 & 1 & 2,8 & 5,1 & 6,8 & 6,2 & 5,6 \\
\hline 3 & 6 & 2 & 1,8 & 6,2 & 3,7 & 4 & 6 \\
\hline 3 & 6 & 3 & 4,9 & 4,8 & 6 & 5,2 & 9 \\
\hline 3 & 6 & 4 & 5 & 5 & 7,8 & 6 & 6 \\
\hline 3 & 7 & 1 & 3,2 & 6,3 & 7,2 & 6,4 & 6,1 \\
\hline 3 & 7 & 2 & 4,7 & 7 & 7,3 & 6,7 & 4,8 \\
\hline 3 & 7 & 3 & 3,7 & 6,7 & 5,8 & 6,9 & 6,7 \\
\hline 3 & 7 & 4 & 5 & 6,6 & 5,9 & 6,6 & 5,9 \\
\hline 3 & 8 & 1 & 3,4 & 8,2 & 6,7 & 8,2 & 5,8 \\
\hline 3 & 8 & 2 & 3,5 & 8,4 & 8,5 & 8,4 & 8,8 \\
\hline 3 & 8 & 3 & 1,4 & 8,4 & 8,5 & 8 & 8,6 \\
\hline 3 & 8 & 4 & 3,7 & 8,7 & 3,8 & 1,3 & 3,2 \\
\hline 3 & 9 & 1 & 2,3 & 7,9 & 3,1 & 8,3 & 6,4 \\
\hline 3 & 9 & 2 & 1,4 & 8,6 & 8,6 & 1,3 & 1,2 \\
\hline 3 & 9 & 3 & 1,8 & 2,8 & 8,7 & 1,8 & 8,2 \\
\hline 3 & 9 & 4 & 3,6 & 8,2 & 8,6 & 2,6 & 1,4 \\
\hline 3 & 10 & 1 & 5,6 & 7,3 & 9 & 1 & 9 \\
\hline 3 & 10 & 2 & 2 & 9 & 9 & 9 & 1,3 \\
\hline 3 & 10 & 3 & $1, \overline{6}$ & 8,3 & 8,8 & 9 & 2,1 \\
\hline 3 & 10 & 4 & 1,8 & 8,6 & 8,9 & 7,7 & 1,2 \\
\hline 4 & 1 & 1 & 3,4 & 5,4 & 4,9 & 5,3 & 4 \\
\hline 4 & 1 & 2 & 1,6 & 6,8 & 1,6 & 2,6 & 2 \\
\hline 4 & 1 & 3 & 2 & 7,6 & 2,7 & 5 & 6,6 \\
\hline 4 & 1 & 4 & 1,9 & 7,3 & 4,9 & 5,6 & 6,8 \\
\hline 4 & 2 & 1 & 1,6 & 8,7 & 1,7 & 6,5 & 2,8 \\
\hline 4 & 2 & 2 & 2,5 & 6,7 & 2,6 & 7,5 & 8,5 \\
\hline 4 & 2 & 3 & 2,2 & 6 & 1,9 & 3 & 7,4 \\
\hline 4 & 2 & 4 & 2,5 & 8,8 & 4,3 & 1,6 & 1,4 \\
\hline 4 & 3 & 1 & 1,3 & 1,3 & 7,2 & 8,9 & 8,1 \\
\hline 4 & 3 & 2 & 1,2 & 7,8 & 6,7 & 5,7 & 8,7 \\
\hline 4 & 3 & 3 & 1,4 & 8 & 8,2 & 8,3 & 7,6 \\
\hline 4 & 3 & 4 & 1,4 & 6,8 & 6,6 & 7,5 & \\
\hline 4 & 4 & 1 & 1,8 & 1,9 & 3,3 & 6,2 & 6,5 \\
\hline 4 & 4 & 2 & 2 & 3 & 3,1 & 2,8 & \\
\hline 4 & 4 & 3 & 2,5 & 2,6 & 3,6 & 1,8 & 7 \\
\hline 4 & 4 & 4 & 1,9 & 3,1 & 2,8 & 1,9 & \\
\hline 4 & 5 & 1 & 1,1 & 4,9 & 3,6 & 8,9 & 3,5 \\
\hline 4 & 5 & 2 & 1,3 & 4,2 & 2,6 & 2,1 & \\
\hline 4 & 5 & 3 & 1,1 & 8,9 & 5,1 & 6,6 & 5 \\
\hline 4 & 5 & 4 & 1,5 & 8,8 & 8,4 & 5,4 & 2,6 \\
\hline 4 & 6 & 1 & 1 & 6,8 & 3,7 & 3 & 1,9 \\
\hline 4 & 6 & 2 & 4,6 & 5,3 & 5,8 & 6,2 & 6,8 \\
\hline 4 & 6 & 3 & 2,8 & 6 & 2,7 & 3,9 & \\
\hline 4 & 6 & 4 & 2,9 & 7 & 3,9 & 3,9 & 3,9 \\
\hline 4 & 7 & 1 & 2,4 & 5,8 & 5,3 & 5,7 & \\
\hline 4 & 7 & 2 & 2,2 & 7,3 & 4,5 & 4,3 & \\
\hline 4 & 7 & 3 & 2,4 & 5,5 & 3,4 & 1,4 & 7,4 \\
\hline 4 & 7 & 4 & 5,3 & 6,4 & 5,5 & 2 & 5,6 \\
\hline 4 & 8 & 1 & 2,3 & 8,2 & 2 & 5,7 & 1,6 \\
\hline 4 & 8 & 2 & 1,2 & 8,7 & $4, \overline{9}$ & 4,3 & \\
\hline 4 & 8 & 3 & 1,5 & 8,3 & 1,8 & 1,4 & 2,4 \\
\hline 4 & 8 & 4 & 3,7 & 8,2 & 1,3 & 2 & \\
\hline 4 & 9 & 1 & 2,6 & 6,8 & 8,7 & 7,6 & 3,8 \\
\hline 4 & 9 & 2 & 1,5 & 5,4 & 6,7 & 1,4 & 8 \\
\hline
\end{tabular}




$\begin{array}{rrrrrrrr}4 & 9 & 3 & 2 & 8,5 & 1,6 & 1,8 & 8,3 \\ 4 & 9 & 4 & 2,4 & 2,1 & 1,4 & 8 & 5,8 \\ 4 & 10 & 1 & 5,2 & 8,7 & 7,4 & 9 & 3,6 \\ 4 & 10 & 2 & 1 & 9 & 4,3 & 6 & 3 \\ 4 & 10 & 3 & 1,2 & 7,8 & 6,1 & 2,6 & 3,3 \\ 4 & 10 & 4 & 1,3 & 8,8 & 1,9 & 1,2 & 1\end{array}$

Anexo 17. Dados originais relativo aos atributos de textura consistência, viscosidade, presença de grânulos e impressão global obtido pela "ADQ" da Análise Sensorial do iogurte de leite de cabra após o quinto dia após o processamento.

Obs: Tratamento $1=$ carragena/pectina $0,1 \%$; Tratamento 2=pectina $0,5 \%$; Tratamento 3=Leite em pó desnatado; Tratamento 4=testemunha.

\begin{tabular}{|c|c|c|c|c|c|c|}
\hline Tratamento & Provador & Repetições & Consistência & Viscosidade & Pres. de grânulos & Impr. Global \\
\hline 1 & 1 & 1 & 3,3 & 7,3 & 2,5 & 3,9 \\
\hline 1 & 1 & 2 & 1,2 & 6,5 & 1,3 & 5,3 \\
\hline 1 & 1 & 3 & 2,1 & 3,3 & 2,2 & 4,1 \\
\hline 1 & 1 & 4 & 3,6 & 3,5 & 2 & 7,9 \\
\hline 1 & 2 & 1 & 1,5 & 2,2 & $5, \overline{7}$ & 4,9 \\
\hline 1 & 2 & 2 & 1,7 & 1,4 & 2,3 & 4,4 \\
\hline 1 & 2 & 3 & 1,3 & 1,9 & 4,8 & 4,3 \\
\hline 1 & 2 & 4 & 0,3 & 0,5 & 0,2 & 5 \\
\hline 1 & 3 & 1 & 5,8 & 8 & 7,8 & 8 \\
\hline 1 & 3 & 2 & 1,7 & 4,9 & 1,2 & 5,6 \\
\hline 1 & 3 & 3 & 8,3 & 8,7 & 1,2 & 8,9 \\
\hline 1 & 3 & 4 & 1,7 & 5 & 1,3 & 7,1 \\
\hline 1 & 4 & 1 & 3,4 & 2 & 2 & 2,8 \\
\hline 1 & 4 & 2 & 2,1 & 2,5 & 2 & 3,7 \\
\hline 1 & 4 & 3 & 1,8 & 1,8 & 4,8 & 1,8 \\
\hline 1 & 4 & 4 & 2 & 2,1 & 2 & 2,9 \\
\hline 1 & 5 & 1 & 2,1 & 3,4 & 8,6 & 5,7 \\
\hline 1 & 5 & 2 & 2,4 & 1,2 & 8,2 & 7,6 \\
\hline 1 & 5 & 3 & 5,5 & 7,3 & 7 & 7,9 \\
\hline 1 & 5 & 4 & 3,7 & 5,2 & 8,1 & 8,9 \\
\hline 1 & 6 & 1 & 4,1 & 2,9 & 4 & 4 \\
\hline 1 & 6 & 2 & 3,1 & 2,9 & 1 & 4,1 \\
\hline 1 & 6 & 3 & 4 & 4,1 & 1,9 & 5,3 \\
\hline 1 & 6 & 4 & 2 & 2,9 & 1,9 & 5,7 \\
\hline 1 & 7 & 1 & 3,5 & 4,5 & 2 & 3,6 \\
\hline 1 & 7 & 2 & 3,1 & 3,2 & 2,8 & 4,9 \\
\hline 1 & 7 & 3 & 6,1 & 4 & 6,1 & 5,6 \\
\hline 1 & 7 & 4 & 3,2 & 4,3 & 4,8 & 6,3 \\
\hline 1 & 8 & 1 & 5 & 2,9 & 2,6 & 6,2 \\
\hline 1 & 8 & 2 & 1,3 & 1,7 & 3,4 & 5,8 \\
\hline 1 & 8 & 3 & 2,1 & 1,6 & 2 & 6,7 \\
\hline 1 & 8 & 4 & 1,3 & 1,1 & 1,2 & 5,2 \\
\hline 1 & 9 & 1 & 1,7 & 7,4 & 1,5 & 5,4 \\
\hline 1 & 9 & 2 & 1,3 & 7,8 & 1,3 & 5,2 \\
\hline 1 & 9 & 3 & 1,2 & 1,9 & 1,2 & 8,5 \\
\hline 1 & 9 & 4 & 1,6 & 8,5 & 1,6 & 6,5 \\
\hline 1 & 10 & 1 & 2 & 2,6 & 5,3 & 3,1 \\
\hline 1 & 10 & 2 & 1,2 & 1,3 & 1,4 & 3,6 \\
\hline 1 & 10 & 3 & 1 & 3,3 & 1 & 3,7 \\
\hline 1 & 10 & 4 & 1,5 & 1 & 1 & 1,8 \\
\hline 2 & 1 & 1 & 8,1 & 3,5 & 2,5 & 2,5 \\
\hline 2 & 1 & 2 & 7,1 & 2 & 1,2 & 6 \\
\hline 2 & 1 & 3 & 8,4 & 5 & 2,2 & 3,4 \\
\hline 2 & 1 & 4 & 8,2 & 7,9 & 6,7 & 3,9 \\
\hline 2 & 2 & 1 & 8,8 & 2,7 & 1,8 & 7,3 \\
\hline 2 & 2 & 2 & 6 & 1,6 & 1,8 & 5,1 \\
\hline 2 & 2 & 3 & 5,9 & 5 & 5,5 & 1,8 \\
\hline
\end{tabular}




\begin{tabular}{|c|c|c|c|c|c|c|}
\hline 2 & 2 & 4 & 8,5 & 2,1 & 1,7 & 1,6 \\
\hline 2 & 3 & 1 & 8,8 & 8,8 & 1,1 & 8,8 \\
\hline 2 & 3 & 2 & 7,8 & 8,4 & 1,3 & 8,3 \\
\hline 2 & 3 & 3 & 8,7 & 8,6 & 1,2 & 8,2 \\
\hline 2 & 3 & 4 & 8,5 & 8,3 & 1,3 & 8,6 \\
\hline 2 & 4 & 1 & 8,3 & 6,2 & 7,4 & 2,8 \\
\hline 2 & 4 & 2 & 5,1 & 3,3 & 5,2 & 2,8 \\
\hline 2 & 4 & 3 & 5,1 & 3,8 & 8,1 & 2,6 \\
\hline 2 & 4 & 4 & 5,1 & 3,2 & 5,2 & 1,9 \\
\hline 2 & 5 & 1 & 8,8 & 8,1 & 1,6 & 6,2 \\
\hline 2 & 5 & 2 & 8,7 & 8,5 & 1,7 & 8,2 \\
\hline 2 & 5 & 3 & 8,6 & 7,8 & 1,3 & 9 \\
\hline 2 & 5 & 4 & 7,1 & 6,6 & 8,2 & 8,8 \\
\hline 2 & 6 & 1 & 7,4 & 7,2 & 7,9 & 5,1 \\
\hline 2 & 6 & 2 & 6,3 & 5,4 & 5,7 & 4,1 \\
\hline 2 & 6 & 3 & 6 & 5,3 & 7,9 & 4,3 \\
\hline 2 & 6 & 4 & 7 & 7,4 & 9 & 2,7 \\
\hline 2 & 7 & 1 & 7,9 & 7,5 & 3 & 3,8 \\
\hline 2 & 7 & 2 & 4,6 & 5 & 6,4 & 6,4 \\
\hline 2 & 7 & 3 & 8,1 & 7 & 6,6 & 4,5 \\
\hline 2 & 7 & 4 & 7,7 & 7,3 & 6,2 & 2,5 \\
\hline 2 & 8 & 1 & 7,9 & 7,3 & 8,8 & 4,9 \\
\hline 2 & 8 & 2 & 7 & 6,3 & 8,8 & 5 \\
\hline 2 & 8 & 3 & 8,8 & 8,3 & 8,9 & 4 \\
\hline 2 & 8 & 4 & 7,8 & 7,5 & 8,6 & 3,4 \\
\hline 2 & 9 & 1 & 8,8 & 3,9 & 1,6 & 6 \\
\hline 2 & 9 & 2 & 8,2 & 1,4 & 3,6 & 5,2 \\
\hline 2 & 9 & 3 & 8,8 & 5 & 1,3 & 4,9 \\
\hline 2 & 9 & 4 & 8,5 & 2 & 3,8 & 3,7 \\
\hline 2 & 10 & 1 & 7,6 & 5,9 & 6,4 & 3,7 \\
\hline 2 & 10 & 2 & 7,8 & 9 & 1 & 4,2 \\
\hline 2 & 10 & 3 & 9 & 5 & 1 & 5,1 \\
\hline 2 & 10 & 4 & 8,9 & 4,3 & 1 & 1,7 \\
\hline 3 & 1 & 1 & 6,1 & 4,4 & 2,4 & 3,8 \\
\hline 3 & 1 & 2 & 8 & 6,7 & 1,1 & 6,9 \\
\hline 3 & 1 & 3 & 8 & 4,9 & 2,2 & 7,3 \\
\hline 3 & 1 & 4 & 7,1 & 7,1 & 3,5 & 6,5 \\
\hline 3 & 2 & 1 & 8,2 & 2,4 & 2,9 & 6,1 \\
\hline 3 & 2 & 2 & 7,3 & 2 & 1,9 & 7 \\
\hline 3 & 2 & 3 & 5,2 & 5,3 & 1,3 & 7,3 \\
\hline 3 & 2 & 4 & 2,8 & 1,2 & 0,2 & 8 \\
\hline 3 & 3 & 1 & 8,8 & 8,8 & 1,1 & 8,7 \\
\hline 3 & 3 & 2 & 8,2 & 8,4 & 1,3 & 8,3 \\
\hline 3 & 3 & 3 & 8,6 & 8,8 & 2,2 & 8,4 \\
\hline 3 & 3 & 4 & 8,3 & 8,1 & 1,3 & 8,7 \\
\hline 3 & 4 & 1 & 8,3 & 7,3 & 6,2 & 5,1 \\
\hline 3 & 4 & 2 & 7,3 & 5,3 & 4,1 & 5 \\
\hline 3 & 4 & 3 & 4,2 & 5 & 7,1 & 3,5 \\
\hline 3 & 4 & 4 & 3,3 & 5,2 & 3,5 & 4 \\
\hline 3 & 5 & 1 & 8,3 & 8,3 & 1,5 & 8,9 \\
\hline 3 & 5 & 2 & 8,3 & 8,7 & 1,4 & 8,9 \\
\hline 3 & 5 & 3 & 8,6 & 7,8 & 1,6 & 9 \\
\hline 3 & 5 & 4 & 8,3 & 7,3 & 1,5 & 8,9 \\
\hline 3 & 6 & 1 & 6,2 & 6,1 & 6 & 7,2 \\
\hline 3 & 6 & 2 & 5,2 & 4,3 & 3,8 & 5,1 \\
\hline 3 & 6 & 3 & 7 & 6,4 & 6,2 & 8,1 \\
\hline 3 & 6 & 4 & 5,9 & 6,1 & 7,7 & 7,6 \\
\hline 3 & 7 & 1 & 6,8 & 6,3 & 5,7 & 4,1 \\
\hline 3 & 7 & 2 & 5,8 & 6,3 & 5,6 & 7,1 \\
\hline 3 & 7 & 3 & 7,2 & 5,4 & 5,3 & 5 \\
\hline 3 & 7 & 4 & 6,2 & 6,9 & 5,6 & 4 \\
\hline 3 & 8 & 1 & 7 & 6,6 & 8,2 & 8,1 \\
\hline 3 & 8 & 2 & 8,2 & 7,7 & 8,8 & 6 \\
\hline 3 & 8 & 3 & 8,3 & 7,7 & 8,3 & 5,4 \\
\hline 3 & 8 & 4 & 3,1 & 2,4 & 3,7 & 8,8 \\
\hline 3 & 9 & 1 & 2,3 & 6 & 8,6 & 5 \\
\hline 3 & 9 & 2 & 8,6 & 1,3 & 1,3 & 8,5 \\
\hline
\end{tabular}




\begin{tabular}{|c|c|c|c|c|c|c|}
\hline 3 & 9 & 3 & 6,1 & 5,3 & 8,6 & 8,6 \\
\hline 3 & 9 & 4 & 4,5 & 4,6 & 1,5 & 7,3 \\
\hline 3 & 10 & 1 & 7,5 & 5,9 & 4,8 & 2,5 \\
\hline 3 & 10 & 2 & 8,4 & 8,4 & 1,4 & 2,9 \\
\hline 3 & 10 & 3 & 9 & 4,9 & 3,2 & 7,6 \\
\hline 3 & 10 & 4 & 8,9 & 3,5 & 1 & 8 \\
\hline 4 & 1 & 1 & 4,5 & 4,5 & 2,5 & 3,8 \\
\hline 4 & 1 & 2 & 3,5 & 6,8 & 2,9 & 5,3 \\
\hline 4 & 1 & 3 & 2,7 & 7,7 & 2,2 & 4,2 \\
\hline 4 & 1 & 4 & 4,9 & 4,8 & 2,9 & 6,5 \\
\hline 4 & 2 & 1 & 3,5 & 2,2 & 7,5 & 3,8 \\
\hline 4 & 2 & 2 & 2,3 & 1,9 & 2 & 6,4 \\
\hline 4 & 2 & 3 & 2,5 & 2,5 & 2,4 & 4,3 \\
\hline 4 & 2 & 4 & 0,5 & 0,6 & 0,2 & 7,5 \\
\hline 4 & 3 & 1 & 6,7 & 6,9 & 8,8 & 8 \\
\hline 4 & 3 & 2 & 7,5 & 6,6 & 8,8 & 6,2 \\
\hline 4 & 3 & 3 & 8,8 & 8,9 & 1,3 & 8,7 \\
\hline 4 & 3 & 4 & 6 & 5,4 & 1,3 & 8,1 \\
\hline 4 & 4 & 1 & 6,2 & 3,4 & 4,8 & 2,8 \\
\hline 4 & 4 & 2 & 3,5 & 4,3 & 3 & 1,9 \\
\hline 4 & 4 & 3 & 2,5 & 2,7 & 5,8 & 1,7 \\
\hline 4 & 4 & 4 & 2 & 2,1 & 2,6 & 2,7 \\
\hline 4 & 5 & 1 & 4,1 & 3,8 & 8,9 & 5,7 \\
\hline 4 & 5 & 2 & 2,8 & 1,9 & 8,2 & 7,5 \\
\hline 4 & 5 & 3 & 5,6 & 6,7 & 6,7 & 8 \\
\hline 4 & 5 & 4 & 8 & 5,6 & 3 & 8,9 \\
\hline 4 & 6 & 1 & 5,3 & 4,1 & 2,9 & 3,9 \\
\hline 4 & 6 & 2 & 7,2 & 6,6 & 6,6 & 6,1 \\
\hline 4 & 6 & 3 & 3 & 2,9 & 4 & 6,4 \\
\hline 4 & 6 & 4 & 2,9 & 3,9 & 2,6 & 4,7 \\
\hline 4 & 7 & 1 & 4,1 & 4,9 & 5 & 4,4 \\
\hline 4 & 7 & 2 & 3,6 & 4,1 & 3,8 & 5,6 \\
\hline 4 & 7 & 3 & 4,5 & 2,8 & 6,9 & 6,1 \\
\hline 4 & 7 & 4 & 4,6 & 6 & 5,3 & 5,3 \\
\hline 4 & 8 & 1 & 4,9 & 2,3 & 6,4 & 4,8 \\
\hline 4 & 8 & 2 & 3,4 & 4 & 7,7 & 7,5 \\
\hline 4 & 8 & 3 & 1,9 & 1,3 & 2,8 & 5,8 \\
\hline 4 & 8 & 4 & 1,3 & 1,2 & 1,6 & 6,5 \\
\hline 4 & 9 & 1 & 6,9 & 4 & 8,3 & 7,4 \\
\hline 4 & 9 & 2 & 2,6 & 1,3 & 2,7 & 4,5 \\
\hline 4 & 9 & 3 & 1,4 & 2,5 & 8,7 & 4,7 \\
\hline 4 & 9 & 4 & 1,5 & 8,5 & 6,2 & 5,6 \\
\hline 4 & 10 & 1 & 2,6 & 1,2 & 6,8 & 2,9 \\
\hline 4 & 10 & 2 & 1,1 & 1,2 & 1,8 & 4 \\
\hline 4 & 10 & 3 & 2,5 & 7,7 & 4,4 & 5,1 \\
\hline 4 & 10 & 4 & 1,4 & 1 & 1 & 9 \\
\hline
\end{tabular}

Anexo 18. Dados originais relativo aos atributos de sabor doce, ácido, salgado, amargo, característico, obtido pela "ADQ" da Análise Sensorial do iogurte de leite de cabra após o quinto dia após o processamento Obs: Tratamento $1=$ carragena/pectina $0,1 \%$; Tratamento $2=$ =pectina $0,5 \%$; Tratamento 3=Leite em pó desnatado; Tratamento 4=testemunha.

$\begin{array}{rr}\text { Tratamento } & \text { Provador } \\ 1 & 1 \\ 1 & 1 \\ 1 & 1 \\ 1 & 1 \\ 1 & 2 \\ 1 & 2 \\ 1 & 2 \\ 1 & 2\end{array}$

$\begin{array}{rrr}\text { Repetições } & \text { Doce } & \text { Ácido } \\ 1 & 2,9 & 5,2 \\ 2 & 1,5 & 1,6 \\ 3 & 1,7 & 7,7 \\ 4 & 3,5 & 4,8 \\ 1 & 6,1 & 5,8 \\ 2 & 6,2 & 2,6 \\ 3 & 5,1 & 4,1 \\ 4 & 2,3 & 2,9\end{array}$

Salgado
8,2
1,5
6,2
4,8
2,7
1,3
1,7
2,6

Amargo
4,7
4,2
5
2
3,2
2,9
1,3
1,6

Característico 


\begin{tabular}{|c|c|c|c|c|c|c|c|}
\hline 1 & 3 & 1 & 2,8 & 1,1 & 1,2 & 1,1 & 6,2 \\
\hline 1 & 3 & 2 & 1,8 & 1,5 & 1,2 & 1,3 & 1,3 \\
\hline 1 & 3 & 3 & 1,7 & 1,4 & 1,2 & 1,2 & 8,2 \\
\hline 1 & 3 & 4 & 6,9 & 4,7 & 3,1 & 1,4 & 4,2 \\
\hline 1 & 4 & 1 & 1,6 & 2,3 & 4 & 3,2 & 4,4 \\
\hline 1 & 4 & 2 & 1,7 & 2,8 & 1,8 & 2,8 & 1,8 \\
\hline 1 & 4 & 3 & 1,6 & 4,8 & 3,9 & 3,5 & 1,8 \\
\hline 1 & 4 & 4 & 1,8 & 1,9 & 2 & 3,9 & 2,3 \\
\hline 1 & 5 & 1 & 1,1 & 8,6 & $1, \overline{1}$ & 1,2 & 8,7 \\
\hline 1 & 5 & 2 & 1,2 & 1,4 & 1,1 & 1 & 6,4 \\
\hline 1 & 5 & 3 & 1,1 & 5,2 & 1,1 & 1,1 & 3,5 \\
\hline 1 & 5 & 4 & 1,1 & 1,6 & 1,1 & 1,1 & 8,9 \\
\hline 1 & 6 & 1 & 4,7 & 5,6 & 3,9 & 4,7 & 5,1 \\
\hline 1 & 6 & 2 & 3,1 & 3,9 & 4,2 & 5,7 & 4,9 \\
\hline 1 & 6 & 3 & 3,1 & 6,1 & 5,1 & 5,6 & 6,2 \\
\hline 1 & 6 & 4 & 3,6 & 2,9 & 2,8 & 2,7 & 6,2 \\
\hline 1 & 7 & 1 & 2,9 & 2,5 & 4,2 & 4,3 & 3,9 \\
\hline 1 & 7 & 2 & 2,5 & 4,5 & 4,5 & 3,5 & 3,7 \\
\hline 1 & 7 & 3 & 2 & 6,2 & 3,3 & 2,6 & 5,8 \\
\hline 1 & 7 & 4 & 4 & 2,8 & 3,9 & 4,8 & 6,1 \\
\hline 1 & 8 & 1 & 1,6 & 1,6 & 1,3 & 2,8 & 6,6 \\
\hline 1 & 8 & 2 & 2,1 & 3,5 & 1,3 & 3,8 & 4,1 \\
\hline 1 & 8 & 3 & 1,5 & 2,4 & 1,4 & 6,7 & 6,4 \\
\hline 1 & 8 & 4 & 1,3 & 6,9 & 1,6 & 8,5 & 6 \\
\hline 1 & 9 & 1 & 3,2 & 4,8 & 1,4 & 3,2 & 4,2 \\
\hline 1 & 9 & 2 & 1,4 & 8,3 & 2,7 & 8,5 & 1,6 \\
\hline 1 & 9 & 3 & 1,3 & 7,8 & 3,8 & 6,2 & 7 \\
\hline 1 & 9 & 4 & 3,7 & 6,3 & 4,6 & 7,8 & 7,3 \\
\hline 1 & 10 & $i$ & 1 & 5,3 & 1,5 & 1,9 & 2,5 \\
\hline 1 & 10 & 2 & 1 & 1,7 & 1 & 1 & 2,7 \\
\hline 1 & 10 & 3 & 1 & 7,2 & 1 & 1 & 3,3 \\
\hline 1 & 10 & 4 & 1 & 1 & 1,2 & 1,8 & 1,8 \\
\hline 2 & 1 & 1 & 2,8 & 6,5 & 6,9 & 8 & 4,9 \\
\hline 2 & 1 & 2 & 1,7 & 2,5 & 1,7 & 8,2 & 6,4 \\
\hline 2 & 1 & 3 & 1,7 & 4,9 & 6,8 & 8,5 & 4,8 \\
\hline 2 & 1 & 4 & 1,9 & 6,4 & 6,9 & 6,2 & 2,8 \\
\hline 2 & 2 & 1 & 2 & 4,1 & 2,5 & 2,5 & 7 \\
\hline 2 & 2 & 2 & 5,5 & 6,1 & 0,9 & 1,3 & 6,1 \\
\hline 2 & 2 & 3 & 6 & 7,2 & 3,2 & 6,5 & 1,5 \\
\hline 2 & 2 & 4 & 2,3 & 7,3 & 7 & 7 & 1,3 \\
\hline 2 & 3 & 1 & 2,4 & 1,2 & 1,2 & 1,1 & 8,9 \\
\hline 2 & 3 & 2 & 1,9 & 1,5 & 1,2 & 1,3 & 7,2 \\
\hline 2 & 3 & 3 & 1,3 & 1,7 & 1,2 & 1,2 & 7,7 \\
\hline 2 & 3 & 4 & 6,4 & 4,1 & 2,4 & 1,4 & 8,5 \\
\hline 2 & 4 & 1 & 1,5 & 3,1 & 2,1 & 2,5 & 4,2 \\
\hline 2 & 4 & 2 & 2,7 & 2,7 & 2,6 & 3,9 & 1,8 \\
\hline 2 & 4 & 3 & 1,6 & 3,8 & 2,7 & 5,9 & 2,7 \\
\hline 2 & 4 & 4 & 1,7 & 3,7 & 5 & 6,3 & 1,7 \\
\hline 2 & 5 & 1 & 1,2 & 3,9 & 1,1 & 8,3 & 8,7 \\
\hline 2 & 5 & 2 & 1,2 & 3,6 & 1,1 & 1 & 7,2 \\
\hline 2 & 5 & 3 & 1,1 & 4,8 & 1,1 & 2 & 8,9 \\
\hline 2 & 5 & 4 & 1,1 & 1,2 & 1,1 & 1,1 & 8,4 \\
\hline 2 & 6 & 1 & 3,5 & 6,8 & 3 & 3,6 & 3 \\
\hline 2 & 6 & 2 & 4 & 5,9 & 3,4 & 5,7 & 3,5 \\
\hline 2 & 6 & 3 & 4,4 & 5,3 & 4 & 3,7 & 4,1 \\
\hline 2 & 6 & 4 & 4,8 & 7,1 & 4,9 & 6,9 & 2,9 \\
\hline 2 & 7 & 1 & 3,6 & 1,8 & 3 & 5 & 4,4 \\
\hline 2 & 7 & 2 & 4,5 & 5,2 & 3,2 & 3,2 & 5,2 \\
\hline 2 & 7 & 3 & 2,7 & 2,6 & 2,6 & 5,3 & 3,7 \\
\hline 2 & 7 & 4 & 2,6 & 2,5 & 2,8 & 6,6 & 2,5 \\
\hline 2 & 8 & 1 & 1,6 & 2,5 & 1,4 & 4,3 & 5,8 \\
\hline 2 & 8 & 2 & 1,5 & 2,3 & 1,3 & 4,5 & 4,4 \\
\hline 2 & 8 & 3 & 1,1 & 8,7 & 2 & 8,4 & 1,5 \\
\hline 2 & 8 & 4 & 1,1 & 3,9 & 1,3 & 8 & 4,2 \\
\hline 2 & 9 & 1 & 2,6 & 1,4 & 1,7 & 4,1 & 7,1 \\
\hline 2 & 9 & 2 & 1,4 & 8,3 & 2,7 & 7,1 & 1,6 \\
\hline 2 & 9 & 3 & 3 & 5,6 & 1,5 & 4,9 & 6 \\
\hline
\end{tabular}




\begin{tabular}{|c|c|c|c|c|c|c|c|}
\hline 2 & 9 & 4 & 1,3 & 5,5 & 1,5 & 8,3 & 1,3 \\
\hline 2 & 10 & 1 & 1 & 1,8 & 1,3 & 1,3 & 2,3 \\
\hline 2 & 10 & 2 & 1 & 6,6 & 1 & 1 & 6 \\
\hline 2 & 10 & 3 & 1 & 6,3 & 1 & 2,5 & 7,2 \\
\hline 2 & 10 & 4 & 1 & 1 & 2 & 2,2 & 1 \\
\hline 3 & 1 & 1 & 1,2 & 7,2 & 7,7 & 5 & 5,1 \\
\hline 3 & 1 & 2 & 2 & 7,6 & 2 & 4,1 & 8,2 \\
\hline 3 & 1 & 3 & 1,6 & 8 & 5,2 & 5 & 7,3 \\
\hline 3 & 1 & 4 & 2,9 & 6,9 & 5,6 & 2,8 & 5,5 \\
\hline 3 & 2 & 1 & 5 & 5,3 & 2,3 & 2,7 & 6 \\
\hline 3 & 2 & 2 & 6,4 & 3,3 & 0,3 & 0,3 & 8,7 \\
\hline 3 & 2 & 3 & 8,7 & 6,4 & 2,3 & 1,4 & 6,5 \\
\hline 3 & 2 & 4 & 7,6 & 5 & 1,6 & 1,5 & 6,5 \\
\hline 3 & 3 & 1 & 6,8 & 1,1 & 1,1 & 1,2 & 8,8 \\
\hline 3 & 3 & 2 & 5,2 & 1,2 & 1,2 & 1,3 & 7,9 \\
\hline 3 & 3 & 3 & 1,5 & 1,4 & 1,1 & 1,2 & 8,2 \\
\hline 3 & 3 & 4 & 7,9 & 2 & 1,5 & 1,4 & 8,3 \\
\hline 3 & 4 & 1 & 3,2 & $1, \overline{6}$ & 3,3 & 2,7 & 6 \\
\hline 3 & 4 & 2 & 3,7 & 1,7 & 4,9 & 1,7 & 3,1 \\
\hline 3 & 4 & 3 & 2,9 & 1,7 & 4,8 & 1,7 & 2,6 \\
\hline 3 & 4 & 4 & 3,3 & 2,8 & 3,8 & 2,3 & 4 \\
\hline 3 & 5 & 1 & 1,3 & 4,3 & 1,1 & 1,1 & 8,7 \\
\hline 3 & 5 & 2 & 1,2 & 1,3 & 1,1 & 1 & 8,7 \\
\hline 3 & 5 & 3 & 1,1 & 1,1 & 1,1 & 1,2 & 8,8 \\
\hline 3 & 5 & 4 & 1,1 & 1,4 & 1,1 & 1,1 & 8,9 \\
\hline 3 & 6 & 1 & 1,7 & 3 & 5,8 & 1,9 & 6,3 \\
\hline 3 & 6 & 2 & 4 & 4,8 & 4,1 & 4,3 & 5,8 \\
\hline 3 & 6 & 3 & 5,1 & 3 & 3 & 2,6 & 7,8 \\
\hline 3 & 6 & 4 & 5,7 & 5 & 3,8 & 4,7 & 7,1 \\
\hline 3 & 7 & 1 & 4,4 & 2,9 & 2,5 & 1,9 & 5,2 \\
\hline 3 & 7 & 2 & 5,6 & 6,1 & 3,7 & 2,5 & 6,3 \\
\hline 3 & 7 & 3 & 5,1 & 2,3 & 2 & 4,1 & 4,9 \\
\hline 3 & 7 & 4 & 6,3 & 6,2 & 4,2 & 3,3 & 3,6 \\
\hline 3 & 8 & 1 & 2,9 & 1,7 & 1,1 & 1,8 & 8,1 \\
\hline 3 & 8 & 2 & 5,5 & 3,2 & 1,1 & 1,4 & 6,9 \\
\hline 3 & 8 & 3 & 2,1 & 4 & 3,2 & 6,9 & 4,2 \\
\hline 3 & 8 & 4 & 5,6 & 3,5 & 1,2 & 5 & 8,4 \\
\hline 3 & 9 & 1 & 2 & 1,8 & 1,6 & 1,5 & 1,6 \\
\hline 3 & 9 & 2 & 3,2 & 6,5 & 1,5 & 1,4 & 8,5 \\
\hline 3 & 9 & 3 & 7,7 & 4,4 & 1,3 & 1,3 & 4,5 \\
\hline 3 & 9 & 4 & 6,6 & 7,1 & 4,6 & 2,9 & 7,4 \\
\hline 3 & 10 & 1 & 1 & 1,8 & 1,3 & 4,4 & 2,3 \\
\hline 3 & 10 & 2 & 1 & 1 & 1 & 2,3 & 4,6 \\
\hline 3 & 10 & 3 & 1 & 1 & 1 & 4 & 2,5 \\
\hline 3 & 10 & 4 & 1 & 1 & 1 & 1 & 6,9 \\
\hline 4 & 1 & 1 & 1,2 & 7 & 8,2 & 5,3 & 5,2 \\
\hline 4 & 1 & 2 & 1,6 & 6,4 & 1,6 & 3,8 & 2,1 \\
\hline 4 & 1 & 3 & 1,6 & 5,1 & 5,2 & 5 & 5,1 \\
\hline 4 & 1 & 4 & 4,1 & 5,8 & 6,2 & 3,4 & 5,4 \\
\hline 4 & 2 & 1 & 5 & 5,5 & 2,4 & 2,8 & 3,8 \\
\hline 4 & 2 & 2 & 4,7 & 7,5 & 1,1 & 2,2 & 7,1 \\
\hline 4 & 2 & 3 & 4,1 & 7,1 & 5,1 & 3,4 & 5,3 \\
\hline 4 & 2 & 4 & 5,1 & 3,9 & 1,3 & 1,4 & 7,8 \\
\hline 4 & 3 & 1 & 3,5 & 1,3 & 1,4 & 1,2 & 6,2 \\
\hline 4 & 3 & 2 & 1,3 & 2,5 & 1,2 & 1,3 & 2,3 \\
\hline 4 & 3 & 3 & 2 & 1,3 & 1,1 & 1,2 & 8,7 \\
\hline 4 & 3 & 4 & $7, \overline{3}$ & 3,1 & 2,2 & 1,4 & 6 \\
\hline 4 & 4 & 1 & 2,3 & 2,3 & 3,9 & 2,8 & 5 \\
\hline 4 & 4 & 2 & 1,7 & 3,8 & 3,8 & 5 & 3 \\
\hline 4 & 4 & 3 & 2,1 & 2,6 & 1,8 & 5 & 1,6 \\
\hline 4 & 4 & 4 & 2,5 & 5 & 2,7 & 5 & 3 \\
\hline 4 & 5 & 1 & 1,1 & 8,9 & 1,2 & 1,2 & 8,7 \\
\hline 4 & 5 & 2 & 1,1 & 3,9 & 1,1 & 1 & 6,4 \\
\hline 4 & 5 & 3 & 1,1 & 5,8 & 1,1 & 1,2 & 4 \\
\hline 4 & 5 & 4 & 1,1 & 1,2 & 1,1 & 1,1 & 8,9 \\
\hline 4 & 6 & 1 & 3,5 & 4,8 & 4,9 & 6,6 & 4 \\
\hline 4 & 6 & 2 & 5,1 & 2,7 & 5,1 & 3,2 & 3,5 \\
\hline
\end{tabular}




$\begin{array}{rrrrrrrr}4 & 6 & 3 & 4,3 & 4,3 & 6,1 & 4,6 & 5,2 \\ 4 & 6 & 4 & 2,7 & 3,9 & 7 & 3,7 & 5,1 \\ 4 & 7 & 1 & 1,5 & 2,2 & 3,4 & 3 & 5,8 \\ 4 & 7 & 2 & 3,5 & 5,6 & 4,2 & 4 & 4,4 \\ 4 & 7 & 3 & 3,4 & 4,6 & 1,9 & 2 & 6,5 \\ 4 & 7 & 4 & 4,7 & 4,8 & 5,1 & 3,9 & 5,3 \\ 4 & 8 & 1 & 2 & 2,1 & 1,4 & 4,4 & 5,7 \\ 4 & 8 & 2 & 3 & 1,5 & 1,5 & 2,7 & 7,3 \\ 4 & 8 & 3 & 2,2 & 1,9 & 1,3 & 5,8 & 5,7 \\ 4 & 8 & 4 & 1,3 & 7,2 & 1,3 & 7,1 & 7,1 \\ 4 & 9 & 1 & 5,5 & 1,5 & 1,3 & 1,5 & 1,8 \\ 4 & 9 & 2 & 1,3 & 8,7 & 2,8 & 8,8 & 4,3 \\ 4 & 9 & 3 & 1,3 & 5,5 & 1,3 & 4,9 & 2,1 \\ 4 & 9 & 4 & 1,3 & 8,4 & 1,4 & 4,1 & 1 \\ 4 & 10 & 1 & 1 & 6,7 & 1 & 1 & 5,5 \\ 4 & 10 & 2 & 1 & 7,8 & 1 & 1 & 8,1 \\ 4 & 10 & 3 & 1 & 8,5 & 1 & 1 & 7,5\end{array}$

Anexo 19. Valor de F, obtido da análise de variância, para algumas características químicas do iogurte de leite de cabra

\begin{tabular}{cccccc}
\hline C.V. & G.L. & \multicolumn{4}{c}{ Valor F } \\
\cline { 3 - 6 } & & $\mathrm{pH}$ & Acidez Titulável & Proteína Total & Extrato Seco Total \\
\hline Tratamento & 3 & $6,53^{*}$ & $12,56^{*}$ & $157,89^{*}$ & $89,61^{*}$ \\
(T) & & & & & \\
Período (P) & 1 & $1,61 \mathrm{~ns}$ & $0,19 \mathrm{~ns}$ & $6,11^{*}$ & $3,45 \mathrm{~ns}$ \\
T x P & 3 & $0,17 \mathrm{~ns}$ & $0,74 \mathrm{~ns}$ & $0,60 \mathrm{~ns}$ & $1,31 \mathrm{~ns}$ \\
Bloco & 4 & - & - & - & - \\
Resíduo & 28 & - & - & - & - \\
\hline Total & 39 & - & - & - & - \\
\hline
\end{tabular}

Anexo 20 Valor de F, para os atributos de aparência

\begin{tabular}{ccccccc}
\hline C.V. & G.L. & \multicolumn{5}{c}{ VALOR F } \\
\cline { 3 - 7 } & & Brilho & Cor & Consistência & Viscosidade & Presença de Grânulos \\
\hline Tratamento(T) & 3 & 2,21 ns & $7,85^{*}$ & $68,82^{*}$ & 2,13 ns & $3,39^{*}$ \\
Provador (P) & 9 & - & - & - & - & - \\
Resíduo & 147 & - & - & - & - & - \\
\hline Total & 159 & - & - & - & - & - \\
\hline
\end{tabular}


Anexo 21 Valor de F, para os atributos de textura

\begin{tabular}{ccccc}
\hline C.V. & G.L. & & Valor F \\
\cline { 3 - 5 } & & Consistência & Viscosidade & $\begin{array}{c}\text { Presença de } \\
\text { Grânulos }\end{array}$ \\
\hline Tratamento(T) & 3 & & $15,50^{*}$ & $2,87^{*}$ \\
Provador (P) & 9 & $95,19^{*}$ & - & - \\
Resíduo & 147 & - & - & - \\
\hline Total & 159 & - & - & - \\
\hline
\end{tabular}

Anexo 22 Valor de F, para os atributos de sabor

\begin{tabular}{ccccccc}
\hline C.V. & G.L. & \multicolumn{5}{c}{ VALOR F } \\
\cline { 3 - 7 } & & Ácido & Amargo & Doce & Salgado & Característico \\
\hline Tratamento(T) & 3 & $2,07 \mathrm{~ns}$ & $11,36^{*}$ & $10,35^{*}$ & $0,11 \mathrm{~ns}$ & $6,11^{*}$ \\
Provador (P) & 9 & - & - & - & - & - \\
Resíduo & 147 & - & - & - & - & - \\
\hline Total & 159 & - & - & - & - & - \\
\hline
\end{tabular}

Anexo 23 Valor F, para a impressão global

\begin{tabular}{ccc}
\hline C.V. & G.L. & Valor F \\
\cline { 2 - 3 } & & IG \\
\hline Tratamento(T) & 3 & $14,73^{*}$ \\
Provador (P) & 9 & - \\
Resíduo & 147 & - \\
\hline Total & 159 & - \\
\hline
\end{tabular}




\section{REFERÊNCIAS BIBLIOGRÁFICAS}

ABDEL-BAR, N.; HARRIS, N.D.; RILL, R.L. Purification and properties of an antimicrobial substance produced by Streptococcus bulgaricus. Journal of Food Science, v.52, n.2, p.411-415, 1987.

ALM, L. The therapeutic of various cultures - an overview. In: ROBINSON, R.K. (Ed.) The therapeutic properties of fermented milks. Cambridge: University Press, 1991. cap.3, p.45-64.

AMICE-QUEMENEUR, N.; HALUK, J.P.; HARDY, J.; KRAUTCHENKO, T.P. Influence of the acidification process on the colloidal stability of acidic milk drinks prepared from reconstituted nonfat dry milk. Journal of Dairy Science, v.78, n. 12, p.2683-2690, 1995.

ANIFANTAKIS, E.M.; KANDARAKIS, J.G. Contribution to the study of the composition of goat's milk. Milchwissenschaft, v.35, n.10, p.617-619, 1980.

ARAÚJO, W.M.C.; CARUSO, J.G.B. Iogurte : importância da matéria-prima da cultura láctica e do processamento sobre a qualidade do produto. Informativo do Laticinista, v.11, n.47, p.33-38, fev. 1993.

ARAÚJO, W.M.C.; FREITAS, C.P. de; PIRES, E.M.F.; OLIVEIRA, S.L. de. Utilização de leite de cabra na elaboração de iogurte. Revista do Instituto de Laticínios Cândido Tostes, v.41, n.247, p.37-40, set./out. 1986. 
ARTIGNAN, J.M.; CORKIEU, G.; LACROIX, C. Rheology of pure and mixed kappacarrageenan gels in lactic acid fermentation conditions. Journal of Food Texture, v.28, p. 47-70, 1997.

\section{ASSOCIATION OF OFFICIAL ANALYTICAL CHEMISTS. Official methods of} analysis. 15. ed. Washington, 1995. 2v.

AUGUSTIN, M.A.; CHENG, L.J.; CLARKE, P.T. Effects of preheat treatment of milk powder on the properties of reconstituted set skim yogurts. International Dairy Journal, v.9, n.3/6, p.415-416, may/june. 1999a.

AUGUSTIN, M.A.; PUVANENTHIRAN, A.; MCKINNON, I.R. The effect of $\kappa$-carrageenan conformation on its interation with casein micelles. Internacional Dairy Journal, v.9n .3/6, p.413-414, may/june. 1999b.

BAKER, G.A.; SOUZANETO, J. de. Assessment of the potencial of dual-purpose goats in northeast Brazil. Small Ruminant Research, v.2, n.2, p. 97-105, July 1989.

BASAK, S.; RAMASWAMY, H.S. Simultaneous evaluation of shear rate and time dependency of stirred yogurt rheology as influenced by added pectin and strawberry concentrate. Journal of Food Engineering, v.21, n.3, p.385-393, 1994.

BECKER, T.; PUHAN, Z. Effect of different processes to increase the milk solids nonfat content on the rheological properties of yoghurt. Milchwissenschaft, v.44, n.10, p. 626-629, 1989. 
BEENA, A.; PRASAD, V. Effect of yogurt and bifidus yogurt fortified with skim milk powder, condensed whey and lactose-hydrolysed condensed whey on serum cholesterol and triacylglycerol levels in rats. Journal of Dairy Research, v.64, n.3, p. 453-457, Aug. 1997.

BENEDET, H.D.; CARVALHO, M.V. Caracterização do leite de cabra no Estado de Santa Catarina. Ciência e Tecnologia de Alimentos, v.16, n.2, p.116-119, set./out. 1996.

BONASSI, I.A.; MARTINS, D.; ROÇA, R. de O. Composição química e propriedades físico-químicas do leite de cabra. Ciência e Tecnologia de Alimentos, v.17, n.1, p. 57-63, jan./abr. 1997.

BOTTAZZI,V.; DELLAGLIO, F. Acetaldehyde and diacetyl production by Streptococcus thermophilus and other lactic streptococci. Journal of Dairy Research, v.34, n.2, p.109-113, June 1967.

BRANDÃO, S.C.C. Tecnologia da produção industrial de iogurte. Leite \& Derivados, v.5, n.25, p. 24-38, nov./dez. 1995.

BRASIL.Ministério da Agricultura. Regulamento da inspeção industrial e sanitária de produtos de origem animal, Brasília, 113p. 1980.

BRASIL. Ministério da agricultura. Portaria n.56 de 07 de dezembro de 1999. http://www.agricultura.gov.br/das/dipoa/Port56 (15 de setembro de 200).

BRASIL. Leis e Decretos. Nova legislação de produtos lácteos e de alimentos especiais, diet e enriquecidos. São Paulo: Fonte Comunicações e Editora, 1998. $212 \mathrm{p}$. 
BRUMMEL, S.E.; LEE, K. Soluble hydrocolloids enable fat reduction in process cheese spreads. Journal of Food Science, v.55, n.5, p. 1290-1307, Sept./Oct. 1990.

CHAVES, J.B.P. A análise sensorial na indústria de laticínios. Revista do Instituto de Laticínios Cândido Tostes, v.267-272, n.45, p.38-52, 1990.

CHITARA, M.I.F. Características físico-químicas de alguns frutos cítricos cultivados em Minas Gerais. São Paulo, 1979. 186p. Tese (Doutorado). Faculdade de Ciências Farmacêuticas - Universidade de São Paulo.

CHRISTENSEN, S.H. Pectins. In: GLICKSMAN, M. Food hydrocoloids. Boca Ratom: CRC Press, 1983. v.2, cap. 9, p. 205-230

CONSUMO de iogurte. Leite B, v.11, n.123, p.6, mar.1997.

CORDEIRO, P.R.C. Desenvolvimento da caprinocultura no estado de São Paulo. In: WORKSHOP SOBRE PEQUENOS RUMINANTES, 1, Porto Alegre, 1998. s.n.t.

DE VUYST, L. Bacteriocins produced by Streptococcus thermophilus. In : DE VUYST, L.; VANDAMME, E.J. (Ed.) Bacteriocins of lactic acid bacteria : microbiology, genetics and applications. Oxford : Chapman \& Hall, 1994. cap.3, p.507-509.

DIAS, J.M.; TANEZINI, C.A.; PONTE, I.S. et. al. Características minerais do leite caprino in natura da bacia leiteira de Goiânia. Ciência e Tecnologia de Alimentos, v.15, n.1, p. 24-28, jan.jun. 1995.

DUITSCHAEVER, C.L. Yoghurt from goat milk. Cultured Dairy Products Journal, v. 13, n. 4, p. $20-23,1978$. 
DUTCOSKY, S.D. Análise sensorial de alimentos. Curitiba : Champagnat, 1996. 123p.

EGWU, G.O.; ONYEYILI, P.A.; CHIBUTO, G.A.; AMEH, J.A. Improved produtivity of goats and utilisation of goat milk in Nigeria. Small Ruminant Research, v.16, n.3, p.195-201, Mar. 1995.

FAO, Quarterly Bulletin of Statistics. Roma, v.12, n.1/2. 1999a. 107 p.

FAO, Quarterly Bulletin of Statistics. Roma, v.12, n.3/4. 1999b. 152p.

FARMER, R.E.; SHAHANI, K.M.; REDDY, C.V. Inibitory effect of yogurt components. Journal of Dairy Science, v.58, suppl. 1, p. 787, 1975.

FENNEMA,O.R. Food chemistry. New York: Marcel Decker, 1985. 991p.

FERGUSON, R.; COOPER, G. Utilization of all the milk solids in manufacturing consumer products from goat milk. Journal of Dairy Science, v.61, suppl. 1, p.222, 1978.

FERREIRA, C.L. L.F. Valor terapêutico do iogurte e leite acidófilo. Revista do Instituto Cândido Tostes, v.34, n.202, p. 25-27, mar./abr. 1979.

FIETZ, V.R. Efeitos da pcetina cítrica de alta e baixa metoxilação e da celulose nos níveis séricos de colesterol e triglicerídeos em ratos hiperlipidêmicos. Piracicaba, 1998. 60p. Dissertação (Mestrado). Escola Superior de Agricultura "Luiz de Queiroz" - Universidade de São Paulo. 
FISHER, R.A.; YATES, F. Tabelas estatísticas para biologia, medicina e agricultura. São Paulo : ED USP, 1971. 150p.

FONSECA, L.M.; FONSECA, C.S.P.; BRANDÃO, S.C.C. Propriedades anticarcinogênicas de componentes do leite. Indústria de Laticínios, v.4, n.21, p. 50-56, mai./jun. 1999.

FUENTE, M.A. la; REQUENA, T.; JUAREZ, M. Salt balance in ewe's and goat's milk during storage at chilling and freezing temperatures. Journal of Agricultural and Food Chemistry, v. 5, n. 1, p.82-88, Jan. 1997.

FURTADO, M.M. Leite de cabra: características especiais. Seu uso na alimentação. Intolerância. Revista do Instituto de Laticínios Cândido Tostes, v.36, n. 214, p. 27-37, mar./abr. 1981.

FURTADO, M.M. A arte e a ciência do queijo. 2ed. São Paulo : Globo, 1991. 297p.

FURTADO, M.M.; WOLFSCHOON-POMBO, A.F. Leite de cabra: composição e industrialização. Revista do Instituto de Laticínios Cândido Tostes, v.33, n.198, p.15-17, jul./ago. 1978.

FURTADO, S.M.P. Estabilizantes empregados em leites fermentados e bebidas lácteas. Leite \& Derivados, v.6, n.34, p.62-71, mai./jun., 1997.

GARRUTI, R.S. Metodologia na selesção seqüencial e não-seqüencial de provadores para análise sensorial de alimentos e bebidas. Campinas. 180p. 1976. Tese (Doutorado). Faculdade de Engenharia de Alimentos - Universidade Estadual de Campinas. 
GASTALDI, E.; LAGAUDE, A.; MARCHESSEAU, S.; LA FUENTE, B.T.de. Acid milk gel formation as affected by total solids content. Journal of Food Science, v.62, n.4, p.671-675, 1997.

GILLETTE, M. Aplication of descriptive analysis. Journal of Food Protection, v.47, n. 5, p. $403-409,1984$.

GLICKSMAN,M. Food hydrocoloids. Boca Ratom : CRC Press, 1983. v.2, 199p.

GOMES, M.I.F.V.; BONASSI, I.A.; ROÇA, R. de O. Características químicas, microbiológicas e sensoriais do leite de cabra congelado. Ciência e Tecnologia de Alimentos, v.17, n.2, p.111-114, mai./ago. 1997.

GOODENOUGH, E.R.; KLEYN, D.H. Influence of viable yoghurt microflora on digestion of lactose by rat. Journal of Dairy Science, v.59, n.4, p. 601-606, 1976a.

GOODENOUGH, E.R; KLEYN, D.H Qualitative and quantitative changes in carbohydrates during the manufacture of yogurt. Journal of Dairy Science, v. 59, n. 1, p.45-47, June $1976 b$.

GRAHAM, H.D. Food coloids. Westport : AVI, Publ. 1977. 588p.

GUTIERREZ, L.E. Bioquímica animal. Piracicaba: ESALQ, Departo. de Ciência e Tecnologia Agroindustrial, 1997. 220p.

HAMDAN, I.Y.; KUNSMAN, J.E.Jr.; DEANE, D.D. Acetaldehyde production by combined yogurt cultures. Journal of Dairy Science, v.54, n.7, p.10801082, July 1971. 
HARPER, R. Sensory quality control. In: BIRCH, G.G.; PARKER, K.J. (Ed.)

Control of food quality and food analysis. London: Elsevier Applied Science, 1984. p.181-202.

HASHIMOTO, E.M. Efeito do tratamento térmico de culturas filantes nas características físico-químicas do iogurte de leite de cabra. Londrina, 1994. 87p. Dissertação (Mestrado) Universidade Estadual de Londrina.

HASSAN, A.N.; FRANK, J.F.; FARMER, M.A.; SCHIMDT, K.A.; SHALABI, S.I. Formation of yogurt microstructure and three-dimensional visulization as determined by confocal laser microscopy. Journal of Dairy Science, v.1, n. 1, p.41-53, 1966.

HELM, E.; TROLLE, B. Selection of a taste painel. Wallerstein Laboratories Comunication v. 9, p.181. 1946.

HESS, S.J.; ROBERTS, R.F.; ZIEGLER,G.R. Rheological properties of non-fat yoghurt stabilized using Lactobacillus delbrueckii subsp. bulgaricus producing exopolyssaccharide or using commercial stabilizer systems. Journal of Dairy Science, v.80, n.2, p. 252-263, Feb. 1997.

JANDAL, J.M. Comparative aspects of goat and sheep milk. Small Ruminant Research, v.22, n.2, p.177-185, Sep. 1996.

JENNESS, R. Composition and characteristics of goat milk: review 1968-1979. Journal of Dairy Science, v.63, n.10, p. 1605-1630, Oct. 1980.

KALAB, M.; EMMONS, D.B. Milk-gel structure IV. Microstructure of yoghurts in relation to the presence of thickening agents. Journal of Dairy Research, v.42, n.3, p. 453-458, Oct. 1975. 
KEENAN, T.W.; BILLS, D.D.Metabolism of volatile compounds by starter culture microorganisms. A review. Journal of Dairy Science, v.51, n.7, p. 1561-1567, July 1968.

KEHAGIAS, C.; ZERVOUDAKI, A.; PARLAMA, C. Influence of composition and aditives on properties of set-type yoghurt from goat milk. Small Ruminant Research, v.2, p. 35-45, 1989.

KHATOON, J.A.; JOSHI,V.K. Physico-chemical characteristics of proteose-peptone fraction from goat milk. II amino acid composition, hexose and hexosamine contents. Milchwissenschaft, v.42, n.5, p. 280-281, 1987.

KILARA,A.; SHAHANI, K.M. Lactic fermentacions of dairy foods and their biological significance. Journal of Dairy Science, v.61, n.12, p.1793-1800, Oct. 1978.

KNEIFEL, W.; KAUFMANN, M.; FLEISCHER, A.; ULBERTH, F. Screening of commercially available mesophilic dairy starter cultures: biochemical, sensory and microbiological properties. Journal of Dairy Science, v.75, n.11, p. 3158-3166, 1992.

KROGER, M. Quality of yogurt. Journal of Dairy Science, v.59, n.2, p. 344-350, Feb. 1976.

KURMANN, J.; RASIC, J. L.; KROGER, M. Encyclopedia of fermented fresh milk products. New York: AVI Book, 1992. 368p.

LABORATÓRIO NACIONAL DE REFERÊNCIA ANIMAL. Métodos analíticos oficiais para o controle de produtos de origem animal e seus ingredientes: métodos físicos e químicos. Brasília: Ministério da Agricultura, 1981. v.1. 
LANGENDORFF, V.; CUVELIER, G.; LAUNAY, B.; PARKER, A. Gelation and floculation of casein micelle/carrageenan mixtures. Food Hydrocolloids, v.11, n.1, p.35-40, 1997.

LAYE, I.; KARLESKIND,D.; MORR,C.V. Chemical, microbiological and sensory properties of plain nonfat yogurt. Journal of Food Science, v.58, n.5, p. 991-995, Sep./Oct., 1993.

LEMOS-NETO, M.J.; ALMEIDA, J.E. de. Levantamento da situação da caprinocultura no estado de São Paulo. Zootecnia, v.31, n.1, p.29-46, jan./mar. 1993.

LIN, C.F. Interaction of sulfated polysacharides with proteins. In: GRAHAM, H. D. Food coloids. Westport : AVI Publ., 1977, cap.7, p.320-346.

LOEWENSTEIN, M.; EPSCK, S.J.; BARNHART, H.M.; FRANK, J.F. Research on goat milk products.: a review. Journal of Dairy Science, v.63, n.10, p. 1631-1648, Oct. 1980.

LYON, D.H.; FRANCOMBE, M.A.; HASDELL, T.A.; LAWSON, K. (Ed.) Guidelines for sensory analysis in food product development and quality control. London: Chapman and Hall, 1992. 131p.

MANJUNATH, N.; ABRAHAM, M.; SRINIVASAN, R.A. Comparative biochemical Performances of yoghurt bacteria in cow and goat milk. Egyptian Journal of Dairy Science, v.11, p.111-119, 1983.

MANN, G.V.; SPOERY, A. Studies of a surfactant and cholesteremia in the Maasai. American Journal Clinical Nutritional, v.27, n.1, p.464-469, 1974. 
MISTRY, V.V.; HASSAN, H.N. Manufacture of nonfat yogurt from a high milk protein powder. Journal of Dairy Science, v.75, n.4, p.947-957, Jan./Dec., 1992.

MOIRANO, A.L. Sulfated seaweed polysaccharides. In: GRAHAM, H. D. Food colloids. Westport: AVI Publ. 1977. cap.8, p. 347-381.

MOODLER. H.W.; KALAB, M. Microstructure of yogurt stabilized with milk proteins. Journal of Dairy Science, v.66, n.1, p.430-437, Jan. 1983.

MORI, E.E.M. Métodos sensoriais e físicos para a avaliação de alimentos e bebidas: princípios e aplicação. Campinas: ITAL, 1982. 50p.

NEIROTTI, E.; OLIVEIRA, J.A. de. Produção de iogurte pelo emprego de culturas lácticas mistas. Boletim da Sociedade Brasileira de Ciência e Tecnologia de Alimentos, v.23, n.1/2, p.1-16, jan./jun. 1988.

NELSON, D.B.; SMIT, C.J.B.; WILES, R.R. Commercially important pectic substances. In: GRAHAM,H.D. Food coloids. Westport : AVI Publ., 1977. cap.10, p.418-437.

NEWLANDER, J.A.; ATHERTON, H.V. : Babcock, Gerber, Monjonier tests for fat. In: The chemistry and testing of dairy products. Milwaukee: Olsen Publ., 1964. cap. 4, p. 67-114.

OULD-ELEYA, M.M.O.; BANON, S.D.; HARDY, S. A comparative study of $\mathrm{pH}$ and temperatureon the acidic coagulation of milks from cows, goat and sheep. Journal of Dairy Science, v.78, n.12, p.2675-2682, 1995. 
PANFILI, G.; MANZI, P.; PIZZOFERRATO, L. Influence of thermal and other manufacturing stress on retinol isomerization in milk and dairy products.

Journal of Dairy Research, v.65, n.2, p.253-260, May 1998.

PARK, Y.W.; MAHONEY, A.W.; HENDRICKS, D.G. Bioavailability of iron in goat milk compared with cow milk fed to anemic rats. Journal of Dairy Science, v. 69, n. 10 , p. $2608-2615$, Oct. 1986.

PARNELL-CLUNIES, D.; KAKUDA,Y.; SMITH, A.R. Microstructure of yogurts as affected by heat treatment of milk. Milchwissenchaft, v.42, n.7, p413-417, 1987.

PASQUEL, A. Gomas : utililização e aspectos reológicos. Boletim da Sociedade Brasileira de Ciência e Tecnologia de Alimentos, v.33, n.1, p.86-97, jan./jun.1999.

PAYENS, T.A.J. Light scattering of protein reactivity of polysaccharides especially of carrageenans. Journal of Dairy Science, v.55, n.2, p. 141-150, Feb. 1972.

PENNA, A.L.B; OLIVEIRA, M.N.; BARUFFALDI, R. Avaliação da qualidade dos iogurtes. Leite \& Derivados, v.3, n.16, p.13-20, mai./jun. 1994.

PERDIGÓN, G.; VALDEZ, J.C.; RACHID,M. Antitumor activity of yogurt: study of possible immune mechanisms. Journal of Dairy Research, v.65, n.1, p.129138, Feb. 1998.

PIZZOFERRATO, L.; MANZI, P.; VIVANTI, V.; NICOLETTI, I.; CORRADINI, C.; COGLIANDRO, E. Maillard reaction in milk-based foods:nutricional consequences. Journal of Food Protection, v.61, n.2, p.235-239, 1998. 
PULUSANI, S.R.; RAO, D.R.; SUNKI, G.R. Antimicrobial activity of lactic cultures: partial purification and characterization of antimicrobial compounds produced by Streptococcus thermophilus. Journal of Food Science, v.44, n.2, p. 575-578, Mar./ Apr. 1979.

RADKE-MITCHELL, L.C.; SANDINE, W.E. Influence of temperature on associative growth of Steptococcus thermophilus and Lactobacillus bulgaricus. Journal of Dairy Science, v.69, n.10, p. 2558-2568, Oct. 1986.

RAMASWAMY, H.S.; BASAK, S. Pectin and raspaberry concentrate effects on the rheology of stirred commercial yogurt. Journal of Food Science, v.57, n.2, p. 357-360, Mar./Apr. 1990.

RASH, K. Compositional elements affecting flavor of cultured dairy foods. Journal of Dairy Science, v.73, n. 12, p. 3651-3656, Dec. 1990.

ROHM, H.; LECHNER, F.; LECHNER, M. Microflora of Austrian natural-set yogurt. Journal of Food Protection, v.53, n.6, p. 478-480, June 1990.

RYSSTAD,G.; ABRAHAMSEN, R.K. Formation of volatile aroma compounds and carbon dioxide in yogurt starter grown in cow's and goat's milk. Journal of Dairy Research, v.54, n.2, p. 257-266, May 1987.

RYSSTAD,G.; KNUTSEN, W.J.; ABRAHAMSEN, R.K. Effect of threonine and glycine on acetaldehyde formation in goat's milk yogurt. Journal of Dairy Research, v.57, n.3, p. 401-410, Aug. 1990.

SABOYA, L.V.; OETTERER, M.; OLIVEIRA, A.J. de. Propriedades profiláticas e terapêuticas de leites fermentados-uma revisão. Boletim da Sociedade Brasileira de Ciência e Tecnologia em Alimentos, v.31, n.2, p. 176-185, jul./dez. 1997. 
SALJ, J.P.; ISMAIL, A.A. Effect of initial acidity of plain yogurt on acidity changes during refrigerated storage. Journal of Food Science, v.48, n.1, Jan./Feb. 1983.

SAS Institute. SAS, Cary, 1989-1996.

SHKOLNIK, A.; MALTZ,E.; GORDIN, S. Desert conditions and goat milk production Journal of Dairy Science, v.63, n.10, p.1749-1754, Oct. 1980.

SOUZA, G. Iogurte: tecnologia, consumo, produção em alta. Leite \& Derivados, v.5, n.28, p.44-54, mai./jun. 1996.

SPOTO, M.H.F. Estudos dos componentes relacionados ao sabor e aroma do suco de laranja irradiado. São Paulo, 1993. 127p. Dissertação (Doutorado) - Instituto de Pesquisas Energéticas e Nucleares - Universidade de São Paulo.

STEINER, E.H. Sequencial procedures for triangular tests and paired comparison tasting testes. Journal of Food Technology, v.1, n. 1, p.41-53, 1966.

STONE, H.J.; SIDEL, S.; OLIVIER, A. Sensory evalution by quantitative descriptive analysis. Food Chemistry, v.28, n.11, p.24-34, 1974.

SYRBE, A.; BAUER, W.J.; KLOSTERMEYER, H. Polymer science concepts in dairy systems-na overview of milk protein and food hydrocolloid interaction. International Dairy Journal, n. 8, p. 179-193, 1998.

TAMIME, A.Y.; DEETH, H.C. Yogurt: technology and biochemistry. Journal of Food Protection, v.43, n. 12, p.939-977, Dec. 1980. 
TAMIME, A.Y.; ROBINSON, R.K. Yoghurt. Oxford: Pergamon Press, 1985. 431p.

TAMIME, A.Y.; KALAB, M.; MAHDI, H.A. Microstructure and firmess of Labneh (high solids yoghurt) made from cow's, goat's and sheep's milks by a tradicional method or by ultrafiltration. Food Structure, v.10, n.1, p. 37-44, 1991.

TAYLOR, S.L. Immunologic and allergic properties of cow's milk proteins in humans. Journal of Food Protection, v.49, n.3, p.239-250, Mar. 1986.

THOMOPOULOS, C.; TZIA, C.; MILKAS, D. Influence od processing of solidsfortified milk on coagulation time and quality properties of yogurt. Milchwissenchaft, v.48, n.8, p.426-430, 1993.

TOBA, T; WATANABE, A.; ADACHI, S. Quantitative changes in sugars, especially oligosaccharides, during fermentation and storage of yogurt. Journal of Dairy Science, v.66, n.1, p.17-20, 1983.

TZIBOULA, A.; HORNE, D.S. Influence of milk proteins on $\kappa$-carrageenan gelation. International Dairy Journal, v.9, n.3/6, p. 359-364, May/June, 1999.

URBIENÉ, S.; CIUCKINAS, A.; MARGELYTÉ, J. Physical and chemical properties and the values of goat's, cow's and human milk. Milchwissenschaft, v.52, n. 8 , p. $427-430,1997$.

VAN DENDER, A.C.F.; MORENO, I.; GARCIA, S. Avaliação do uso de culturas filantes e/ou diluição para fabricar iogurte de leite de cabra. Coletânea do Instituto de Tecnologia de Alimentos, v.20, n.1, p. 83-95, jan./jun. 1990. 
VOUTSINAS, L.; PAPPAS, C.; KATSIARI, M. The composition of Alpine goats' milk during lactation in Greece. Journal of Dairy Research, v.57,n.1, p.41-51, Feb.1990.

XU, S.Y.; STANLEY, D.W.; GOFF, H.D.; DAVIDSON, V.J.; MAGNER, M. Le. Hydrocolloid/milk gel formation and properties. Journal of Food Science, v.57, n.1, p.96-102, Jan./Feb. 1992.

WALD, A. Sequencial analysis by Abraham Wald. New York : John Wiley, 1947. $272 p$.

WHISTLER, R.L.; DANIEL, O.R. Carbohydrates. In: FENNEMA, O.R. Food chemistry. New York: Marcell Decker, 1985. cap.3, p123-125; 129-130.

WIGERTZ,K; SVENSSON, V.K.; JAGERSTAD, M. Folate and folate-binding protein content in dairy products. Journal of Dairy Research, v.64, n.2, p.239-252, May 1997.

WOLFSCHOON-POMBO, A.F.; GRANZINOLLI, G.G.M.; FERNANDES, R.M. Sólidos totais do leite, acidez, pH e viscosidade do iogurte. Revista do Instituto de Laticínios Cândido Tostes, v.38, n.227, p. 19-24, mai./jun.1983. 